\author{
Universidade de São Paulo \\ Faculdade de Medicina de Ribeirão Preto
}

\title{
A via de sinalização insulínica (IIS) na diferenciação de castas em Apis mellifera
}

Sergio Vicente de Azevedo

Ribeirão Preto

$-2007-$ 


\section{Universidade de São Paulo \\ Faculdade de Medicina de Ribeirão Preto \\ Departamento de Genética}

\section{A via de sinalização insulínica (IIS) na diferenciação de castas em Apis mellifera}

\section{Sergio Vicente de Azevedo}

Dissertação de Mestrado apresentada

à Faculdade de Medicina de Ribeirão Preto da Universidade de São Paulo para obtenção do título de MESTRE em CIÊNCIAS.

Área de concentração: GENÉTICA

Orientador: Prof. Dr. Klaus Hartfelder

Ribeirão Preto

-2007- 
AUTORIZO A DIVULGAÇÃO TOTAL OU PARCIAL DESTE TRABALHO, POR QUALQUER MEIO CONVENCIONAL OU ELETRÔNICO, PARA FINS DE ESTUDO E PESQUISA, DESDE QUE CITADA A FONTE.

AZEVEDO, SERGIO VICENTE

A via de sinalização insulínica (IIS) na diferenciação de castas em Apis mellifera. Sergio Vicente de Azevedo; orientador: Klaus Harfelder - São Paulo, 2007.

91p.: 39 il.

Dissertação de Mestrado, apresentada à Faculdade de Medicina de Ribeirão Preto/USP - Departamento de Genética.

1. Apis mellifera. 2. Via de sinalização IIS. 3. Receptor de insulina. 4. Diferenciação de casta. 5.Insetos sociais. 


\section{FOLHA DE APROVAÇÃO}

\section{Sergio Vicente de Azevedo}

A via de sinalização insulínica na

diferenciação de castas em Apis mellifera

Dissertação de Mestrado apresentada

à Faculdade de Medicina de Ribeirão Preto da Universidade de São Paulo para obtenção do título de MESTRE em CIÊNCIAS.

Área de concentração: GENÉTICA.

Aprovado em:

Banca examinadora

$\operatorname{Prof}^{\circ}(\mathrm{a}) \operatorname{Dr}^{\circ}(\mathrm{a})$

Instituição Assinatura

$\operatorname{Prof}^{\circ}(a) \operatorname{Dr}^{\circ}(a)$

Instituição Assinatura

$\operatorname{Prof}^{\circ}(\mathrm{a}) \operatorname{Dr}^{\circ}(\mathrm{a})$ Instituição Assinatura 
"O conhecimento de nossas fraquezas nos fortalece" 


\section{Dedico}

À minha família e aos meus amigos, que me abastecem de amor e segurança para continuar trilhando meu caminho. Em especial à minha mãe Perciliana, ao meu pai Silvio, ao meu mano Silvinho e sua esposa Josi (minha maninha), ao meu mano Eduardo e à minha tia Nilza, que foi sinônimo de valentia durante toda a sua passagem na terra.

Amo vocês. 


\section{Agradecimentos}

$>$ Deus, pelas dificuldades e facilidades colocadas diante meu caminho;

$>$ Ao Prof. Dr. Klaus Hartfelder, quem orienta minha carreira científica desde minha graduação. É uma honra ser seu orientado;

$>$ À FAPESP, seu suporte financeiro foi fundamental para a realização de meu mestrado e consequentemente desse trabalho;

$>$ À minha "irmãzinha" Vanessa da Silva Silveira, uma amiga leal, que ficou comigo até altas horas finalizando esse trabalho;

> À Daniela Pereira Garçon "Baixinha", pelo que vivemos juntos e pela amizade que perdura;

> À Marcela Aparecida Framartino Bezerra Laure, sem a sua destreza em dissecar eu não teria conseguido isolar alguns tecidos;

$>$ Ao Luiz Roberto Aguiar, que me auxílio na obtenção do material biológico desse trabalho;

Aos meus parceiros, do Bloco A da genética, Érica, Carlos Lobo, Anete, Karina, Roberto Barchuk, Vera Figueiredo, Alexandre Cristino, Adriana Mendes, Paulo Emílio, Vanessa Bugalho, Marina , Amanda, Weider, Thiago, Ana Durvalina, Aline Mackert, Juliana, Mônica, David, Ana Bonetti, Lilíane, Umberto Moreno, Omar, Ivan, Michele, Rodrigo, Rogério e a todos aqueles que fazem parte do meu convívio;

Aos meus pais Silvio e Perciliana que sempre me apoiaram nas minhas decisões, mesmo que não concordassem;

Aos meus irmãos Silvio e Eduardo, "valeu pela firmeza!!”; 
$>$ À minha "sister in law" Josi, pela irmã que ela é;

Aos professores Ademilson Espencer, Lionel Gonçalvez, Zilá L. P Simões e Márcia Bitondi que sempre se mostraram disponíveis a ajudar:

À minha tia Azair e tio Brasil pelos exemplos que são.

À minha tia Aureny e tio Jair, por toda a retaguarda que vocês dão à família.

$>$ À minha nova parceira de laboratório, Fernanda Carvalho Humann pelo auxílio prestado nesse trabalho;

Às secretárias do departamento de genética: Susi e Maria Aparecida;

Ao departamento de genética por me acolher esses anos todos;

$>$ A todas as pessoas que passaram e passam pela minha vida todos os dias, vocês fazem parte da história e do que eu sou; 


\section{Resumo}

Azevedo, S.V. A via de sinalização insulínica (IIS) na diferenciação de castas em Apis mellifera. 91p. Dissertação (Mestrado) - Faculdade de Medicina de Ribeirão Preto, Universidade de São Paulo, 2007.

O polifenismo facultativo, observado entre rainhas e operárias em insetos altamente eussociais tem como estímulo inicial uma alimentação diferencial na fase larval que afeta tanto o desenvolvimento geral das larvas quanto a diferenciação de órgãos e sistemas, principalmente o sistema reprodutor das fêmeas. A via de sinalização por insulina (IIS) é uma das principais vias que integra o desenvolvimento geral de animais com as suas condições nutricionais. O objetivo desse trabalho foi verificar possíveis relações entre a via de sinalização por insulina e a diferenciação das castas em abelhas Apis mellifera. A partir de análises do genoma de Apis mellifera anotamos genes integrantes desta via e verificamos que há dois genes codificadores para receptores de insulina, InR1 e InR2. Os perfis de transcrição desses dois genes obtidos por RT-PCR quantitativa, em larvas de rainhas e operárias durante o período de troca de alimentação, demonstraram que há diferenças consideráveis nos padrões temporais e nos níveis dos transcritos para os receptores de insulina, InR1 (GB15492) e InR2 (GB18331), dentro de cada casta, como também entre as duas castas. Em rainhas verificamos uma interessante variação na transcrição de $\operatorname{lnR} 1$, que no terceiro instar larval foi cerca de cinco vezes maior que a transcrição de InR2 e no quarto instar seguiu em níveis semelhantes ao de InR2. Essa variação de InR1 pode estar relacionada ao teor de proteínas da geléia real oferecida às larvas de rainhas no terceiro instar, que é maior do que teor 
de proteínas da geléia real oferecida a partir do quarto instar larval. Para as amostras de larvas de operárias observamos que os níveis dos transcritos dos dois receptores, InR1 e InR2, foram baixos no terceiro estágio larval e aumentaram, de maneira semelhante, até o início do quinto estágio larval, o que pode ter sido devido a algum composto existente na geléia de operária que estimule a transcrição dos genes para os receptores de insulina. Foram feitas análises complementares dos níveis de transcrição dos genes $\ln R 1$ e $\operatorname{InR2}$, em amostras de ovários, tanto de operárias quanto de rainhas, e em amostras de operárias adultas cultivadas em diferentes tipos de alimentações. Essas análises complementares evidenciaram que a transcrição dos genes para os receptores de insulina em Apis mellifera foi diferente nos ovários de ambas as castas, quando comparada às amostras de corpo inteiro, e que em operárias o transcrito do InR1 foi dominante ao longo de quase toda a vida adulta, sendo superado pelo transcrito InR2 apenas por volta de 13 e 15 dias.. Além disso, uma relação positiva entre o conteúdo de proteína e a transcrição de InR1 foi observada quando analisamos a sua transcrição em amostras de operárias adultas alimentadas com bee bread, uma dieta rica em proteína. Os resultados obtidos nesse trabalho, juntamente com os de Wheeler e colaboradores (2006), Seehus e colaboradores (2006), e Patel e colaboradores (2007), constituem as primeiras informações da via IIS em Apis mellifera, e servirão de base na busca da relação entre a dieta e os sinais downstream envolvidos na determinação de casta e diferenciação.

Palavras chaves: Apis mellifera, via de sinalização IIS, receptor de insulina, diferenciação de casta, insetos sociais. 


\section{Abstract}

Azevedo, S.V. A via de sinalização insulínica (IIS) na diferenciação de castas em Apis mellifera. 91p. Dissertação (Mestrado) - Faculdade de Medicina de Ribeirão Preto, Universidade de São Paulo, 2007.

The initial stimulus that generates the facultative queen/worker polyphenism in highly social insects is a differential alimentation in the larval stages. It affects the general development of the larvae, as well as the differentiation of organs and systems, especially of the female reproductive system. The insulin signaling pathway (IIS) is one of the main pathways that integrates the general development of animals with their respective nutritional conditions. The aim of this work was to investigate the relationship between IIS and caste differentiation in the honey bee Apis mellifera. Using the available Apis mellifera genome information we annotated genes belonging to this pathway. We noted that there are two genes encoding putative insulin receptors, InR1 and InR2. The transcriptional profiles of these genes were obtained by quantitative RT-PCR of queen and workers larvae, giving special attention the period during which the larval diet changes. These results revealed considerable differences in the temporal patterns and levels of the transcripts of two the insulin receptor genes, InR1 (GB15492) and InR2 (GB18331) between the two castes and during their respective larval development. For queens we noted an interesting modulation in InR1 transcription: in the third larval instar it was about five fold higher than the transcription of $\operatorname{InR2}$, but in the fourth instar both receptors were transcribed at similar levels. This variation in $\operatorname{InR} 1$ expression may be related to the protein content of royal jelly offered to the queen larvae in third instar, that is higher than the protein content of the royal jelly offered to fourth larvae instar. For the worker larvae 
samples we observed that transcripts levels of the two receptors, $\operatorname{InR} 1$ and $\operatorname{InR} 2$, were low in the third larval stage and increased in parallel until the onset of the fifth larval stage. This may have been due to some compound in the worker jelly which stimulates the transcription of both genes coding for insulin receptors. Complementary analysis of transcription levels of $\operatorname{InR} 1$ and $\operatorname{InR} 2$ were performed on ovaries of queen and worker larvae, and on adult workers maintained on different diets. These complementary analyses highlighted that transcription of the $\ln R$ genes in the larval ovaries of Apis mellifera was differed from the whole body samples. In adult workers the expression of $\operatorname{InR} 1$ was dominant over InR2 during most of the adult life cycle, an inversion was only seen in 13 to 15 days old bees. Furthermore, a positive relationship between protein content and $\operatorname{InR} 1$ transcription was observed when analyzing its transcription in adult workers fed with bee bread, a protein-rich diet. The results of this work, in conjunction with those of Wheeler et al. (2007), Seehus et al. (2006) and Patel et al. (2007), are the first information on the IIS pathway in honey bees and they represent the basis for an in-depth pursuit on the relationship between diet and downstream signallng envolved in caste determination and differentiation.

Key words: Apis mellifera, IIS signaling, insulin receptor, caste differentiation, social insects. 
1. Introdução 1

1.1 Apis mellifera: um organismo modelo para insetos sociais.

1.2 Desenvolvimento de castas em abelhas melíferas ........................................

1.3 O Hormônio Juvenil e Ecdisteróides no processo de diferenciação de castas ..7

1.4 A via de sinalização insulina/receptor de insulina (IIS) ...........................

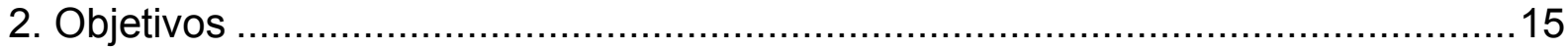

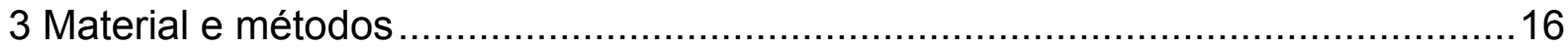

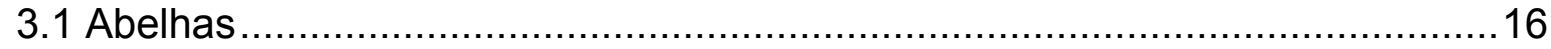

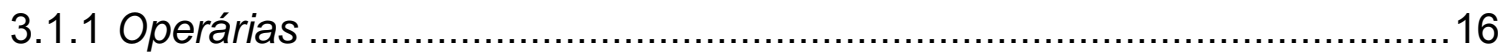

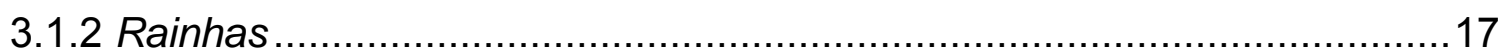

3.2 Dissecção do material biológico ..................................................... 18

3.3 Extração do RNA total e síntese do cDNA.........................................19

3.4 Operárias recém emergidas mantidas sob diferentes tipos de alimentação $\ldots . .20$

3.5 Tratamento com análogo do hormônio juvenil, pyriproxifen (PPN) ................21

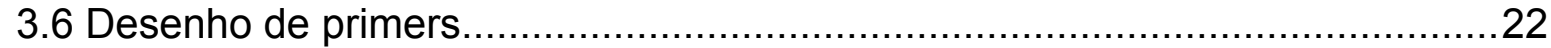

3.7 Reação em cadeia da polimerase (PCR) .........................................23

3.7.1 PCR quantitativa (Real Time PCR) ............................................ 23

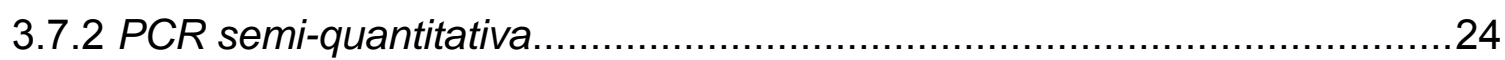

3.8 Preparo das células quimiocompetentes ...........................................26

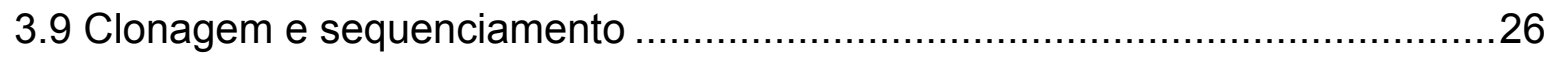

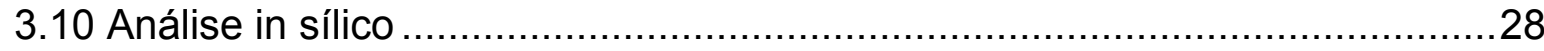

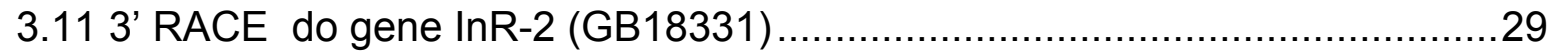

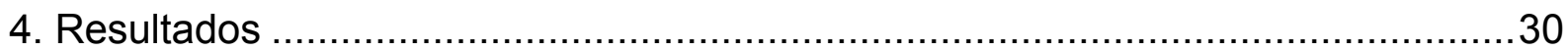

4.1 Identificação de genes candidatos da via IIS no genoma de Apis mellifera.....30

4.1.1 Validação da transcrição de alguns genes integrantes da via IIS ..............32

4.1.2 Anotação dos genes envolvidos na via IIS. .........................................33

4.1.2.1 Gene codificador do receptor de insulina 1 (GB15492) .....................33

4.1.2.2 Gene codificador do receptor de insulina 2 (GB18331) .....................35

4.1.2.3 Gene codificador do substrato do receptor de insulina (Chico) ..........39

4.1.2.4 Gene codificador da quinase ribossomal S6K ................................43

4.1.2.5 Gene codificador do supressor de tumor TSC1 ..............................45

4.1.2.6 Gene codificador de uma proteína alvo de rapamicina (TOR)............46

4.2 Perfil de transcrição dos genes envolvidos na via IIS em Apis mellifera ........48

4.2.1 RT-PCR semiquantitativa do gene codificador de InR2 (GB18331).........48 
4.2.2 RT-PCR quantitativa (qRT-PCR) dos genes InR1 (GB15492) e InR2 (GB18331).

4.2.2.1 Transcrição dos genes codificadores dos receptores de insulina InR1 e InR2 em larvas de rainhas e operárias 50

4.2.2.2 Transcrição dos genes codificadores dos receptores de insulina InR1 e InR2 nos ovários de rainhas e operárias . 52

4.2.2.3 Efeito de tratamento com pyriproxifen sobre a transcrição dos genes InR1 e InR2 em larvas de operárias

4.2.2.4 Efeito da dieta sobre a transcrição dos genes InR1 e InR2 em operárias adultas 55

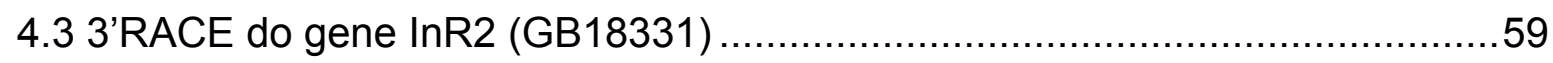

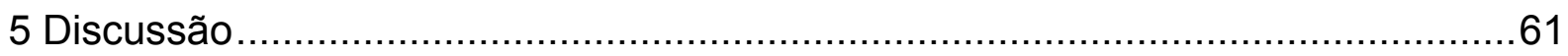

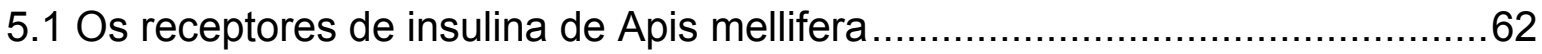

5.1.1 Expressão dos receptores de insulina na fase larval ............................63

5.1.2 Expressão dos receptores de insulina no ovário larval ...........................67

5.1.3. Efeito de hormônio juvenil sobre a transcrição de InR1 e InR2 ...............70

5.1.4. Efeitos da dieta sobre a expressão dos receptores de insulina ...............71

5.2 Análise da cauda 3' do gene InR2 ................................................... 73

5.3 Anotação e sequenciamento outros componentes da via IIS .......................74

5.3.1 O substrato do receptor de insulina Chico de Apis mellifera .....................74

5.3.2 A quinase ribossomal S6K de Apis mellifera .........................................75

5.3.3 O gene supressor de tumor TSC-1 de Apis mellifera ..............................76

5.3.4 O gene codificador para uma proteína alvo de rapamicina (TOR) em Apis

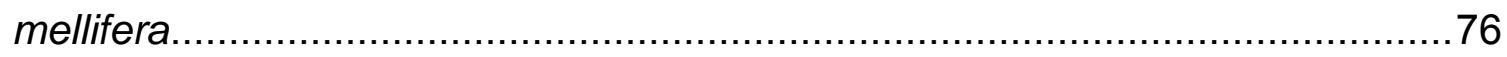

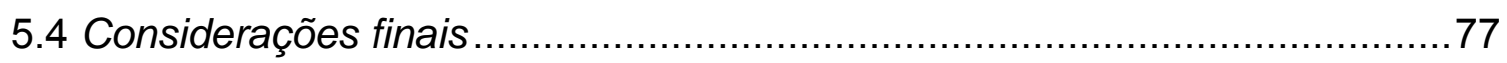

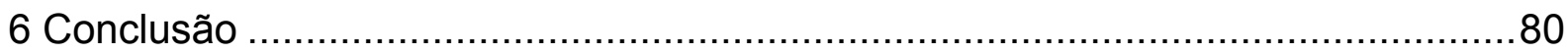

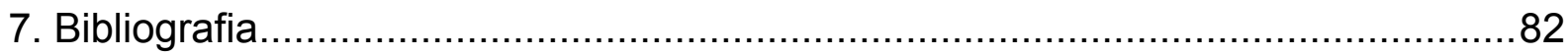




\section{Introdução}

\subsection{Apis mellifera: um organismo modelo para insetos sociais}

Grupos eussociais na ordem Hymenoptera são definidos pela sobreposição de gerações (estrutura matri-filial) em um mesmo ninho e, principalmente, pela presença de castas fenotipicamente distintas. Esta diferenciação morfológicaanatômica das castas garante uma alta eficiência na divisão do trabalho dentro de uma colônia. Na subfamilia Apinae (sensu Michener 2000) apenas duas tribos, os Apini e os Meliponini, apresentam estas características e são as únicas que podem ser classificadas como abelhas altamente eussociais. Pela sua importância econômica e como um modelo de polifenismo facultativo a espécie Apis mellifera tem recebido muita atenção de pesquisadores, tanto em pesquisas básicas como aplicadas, não causando surpresa a inclusão deste inseto na lista dos organismos a terem o seu genoma completamente seqüenciado. O Honey Bee Genome Sequencing Project (HBGSP) foi iniciado em 2003 e atualmente encontra-se disponível, no site http://www.hgsc.bcm.tmc.edu/projects/honeybee/, a versão 4.0 da anotação do genoma da abelha melífera. O sequenciamento completo do genoma e a anotação de famílias gênicas, foram anunciados em publicação recente: The Honey Bee Genome Sequencing Consortium 2006.

Em uma colônia de Apis mellifera são encontrados três tipos de indivíduos: zangões, rainhas e operárias (Figura 1). Cada um destes organismos possui funções específicas que levam à manutenção da colônia. Os zangões são machos gerados a partir de ovos não fecundados, portanto haplóides, cuja única função é o acasalamento com a rainha. As fêmeas, as quais são todas diplóides oriundas de ovos fecundados, são as responsáveis pela divisão de trabalho na colônia. As duas 
castas fêmeas, rainha e operária, embora passem pelos mesmos estágios de desenvolvimento (Figura 2), apresentam diferenças nas taxas de crescimento (Figura 3) e tempo de desenvolvimento larval. Na fase adulta as duas castas são distintas no que diz respeito a sua morfologia, anatomia, fisiologia, longevidade e no seu comportamento (Page \& Peng 2001), o que garante grande eficiência na execução das suas respectivas tarefas: reprodutivas (rainha) e manutenção da colônia (operárias). A rainha requer apenas 15 dias para desenvolver-se a partir do ovo em adulto (Nunes-Silva et al. 2006) e pode viver por mais de um ano (Page \& Peng 2001), além do mais, a rainha é a única a acasalar-se com zangões e depositar, além de ovos haplóides, ovos diplóides. A rainha também exerce forte influência (através de seus feromônios) sobre o comportamento e fisiologia das operárias. Por outro lado, as operárias requerem 20 dias para se desenvolverem a partir do ovo em adultos (Nunes-Silva et al. 2006). Após a emergência como adultas elas passam progressivamente por mudanças comportamentais e fisiológicas correlacionadas com a idade. As operárias mais jovens cuidam da limpeza e alimentação das crias, as com idades intermediarias constroem células,,processam o alimento e guardam a entrada da colméia, enquanto que as abelhas mais velhas forrageiam em busca de alimento, água e material para construção da colméia (Page \& Peng 2001). As operárias de abelhas Apis mellifera vivem em torno de três a seis semanas (Page \& Peng 2001) e, podem também, efetuar postura de ovos não fecundados em condições especiais (Michener 1974, Robinson et al. 1992, Ratnieks 1993, Barron et al. 2001, Makert et al. 2006). 


\subsection{Desenvolvimento de castas em abelhas melíferas}

As diferenças morfológicas e fisiológicas das castas fêmeas surgem durante o desenvolvimento pós-embrionário, no qual larvas fêmeas originalmente bipotentes podem se desenvolver em rainhas ou operárias. A diferenciação de casta depende de estímulos específicos que iniciam esse processo durante o período sensitivo que, de acordo com experimentos de transferências de larvas, varia para os diferentes campos morfogenéticos do corpo (Wilde \& Beetsma 1982, Dedej et al. 1998). A direção do desenvolvimento é determinada durante os primeiros três dias e meio de vida larval por fatores externos, especialmente a nutrição (Rembold \& Hanser 1964; Weaver 1957). As larvas de rainhas são cultivadas em células especiais denominadas realeiras, maiores e dispostas verticalmente na colméia (Figura 4), e nutridas continuamente, ao longo de seus cinco estágios larvais, com uma abundância de geléia real (GR). A geléia real é uma secreção glandular produzida pelas operárias nutridoras e depositada nas células larvais enquanto os alvéolos se encontram abertos e, até mesmo, após o início da fase de tecelagem elas ainda se alimentam, pois os alvéolos de rainhas ainda contêm certa quantidade de alimento que é consumido pelas larvas (Haydak 1970). Embora a composição da geléia real não varie muito ao longo da vida larval da rainha, ela apresenta algumas variações com relação a alguns tipos de nutrientes. Larvas de rainha de até três dias de vida são alimentadas em maior proporção com uma secreção branca enquanto aquelas com quatro dias ou mais recebem em maior quantidade substâncias claras (Haydak 1970). As substâncias brancas e claras da geléia real variam quanto à sua composição, sendo que os conteúdos claros possuem uma concentração de proteína de $110,5 \mathrm{mg} / \mathrm{g}$ e os conteúdos brancos possuem uma concentração de 140,5 mg/g (Haydak 1970). Por outro lado, as larvas de operárias, que são 
cultivadas nas células padrão da colméia (Figura 4), são alimentadas com GR, em menores quantidades, até o $3^{\circ}$ estágio larval, quando o seu tipo de alimentação é alterado para geléia de operária (GO), uma mistura de secreções glandulares suplementadas com pólen e néctar (Rembold 1987). Para as larvas de operárias o período de alimentação encerra-se quando inicia a fase de tecelagem do casulo, enquanto que para as rainhas ainda há alimento nesse período (Haydak 1943).

A alimentação diferenciada em qualidade e quantidade, entre as larvas de operária e rainhas, gera ambientes distintos dentro dos organismos de cada casta, causando respostas específicas que serão projetadas nos diferentes fenótipos das fêmeas adultas. Assim, o ambiente externo no qual a larva se encontra gera alterações no ambiente interno da larva, levando às respostas neuroendócrinas e, finalmente, à diferenciação celular e tecidual em conseqüência de expressão gênica diferencial. Historicamente, o desenvolvimento conceitual destes processos regulatórios do desenvolvimento das castas de abelhas, pode ser verificado nas seguintes revisões: Wilde (1976) descreve como o ambiente nutritivo da larva providencia sinais externos que afetam os processos neuroendócrinos, além de engatilhar a indução morfogenética das castas junto com a via neuroendócrina, o que resulta em um polifenismo de castas, proveniente de um elevado grau de plasticidade do desenvolvimento. Hartfelder e Engels (1998) detalham como o polifenismo que se estabelece a partir da mudança de alimentação entre rainhas e operárias, resulta em uma resposta diferenciada do sistema endócrino, especialmente nos títulos do hormônio juvenil (HJ) e ecdisteróides (Ecd). E por fim, Evans e Wheeler (2000) observaram que larvas destinadas a serem rainhas ou operárias diferem consideravelmente nos seus perfis transcricionais. 


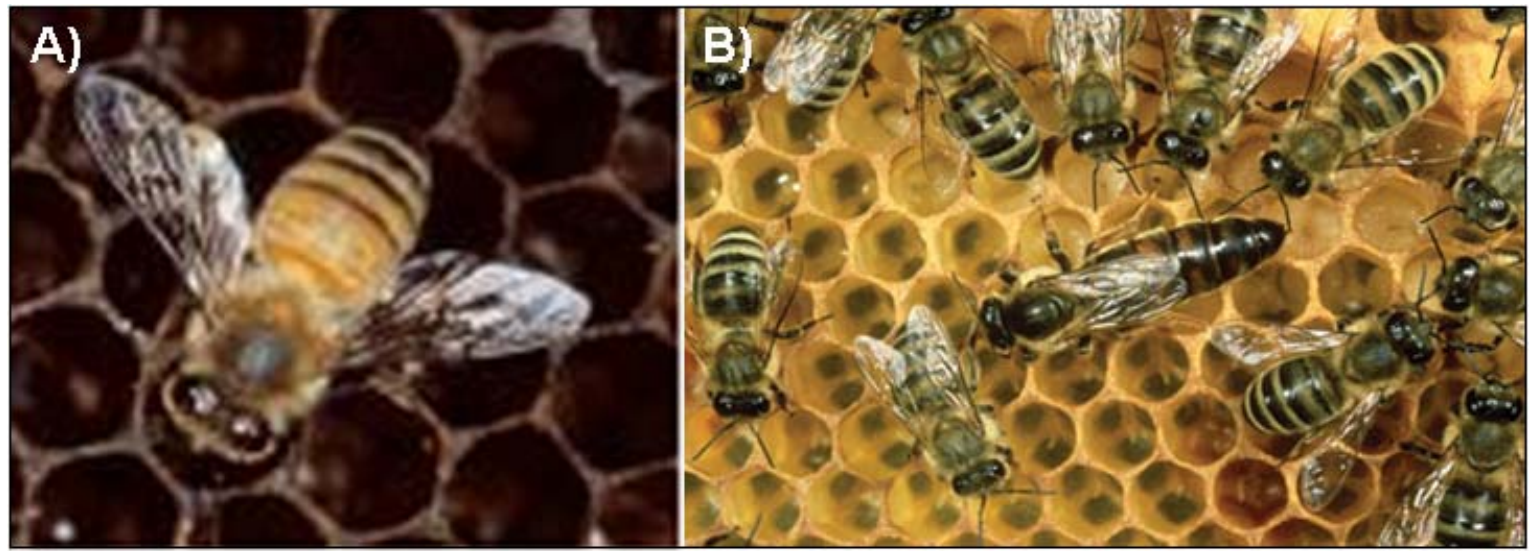

Figura 1: A) Zangão, haplóide, de Apis mellifera (Foto obtida na internet, www.unibayreuth.de/.../toek1/fortner/index.htm) B) Fêmeas, diplóides, de Apis mellifera: a única rainha, com o abdômen mais desenvolvido, se encontra ao centro e as operárias, menores, estão ao redor. (Foto Wilson 2006)

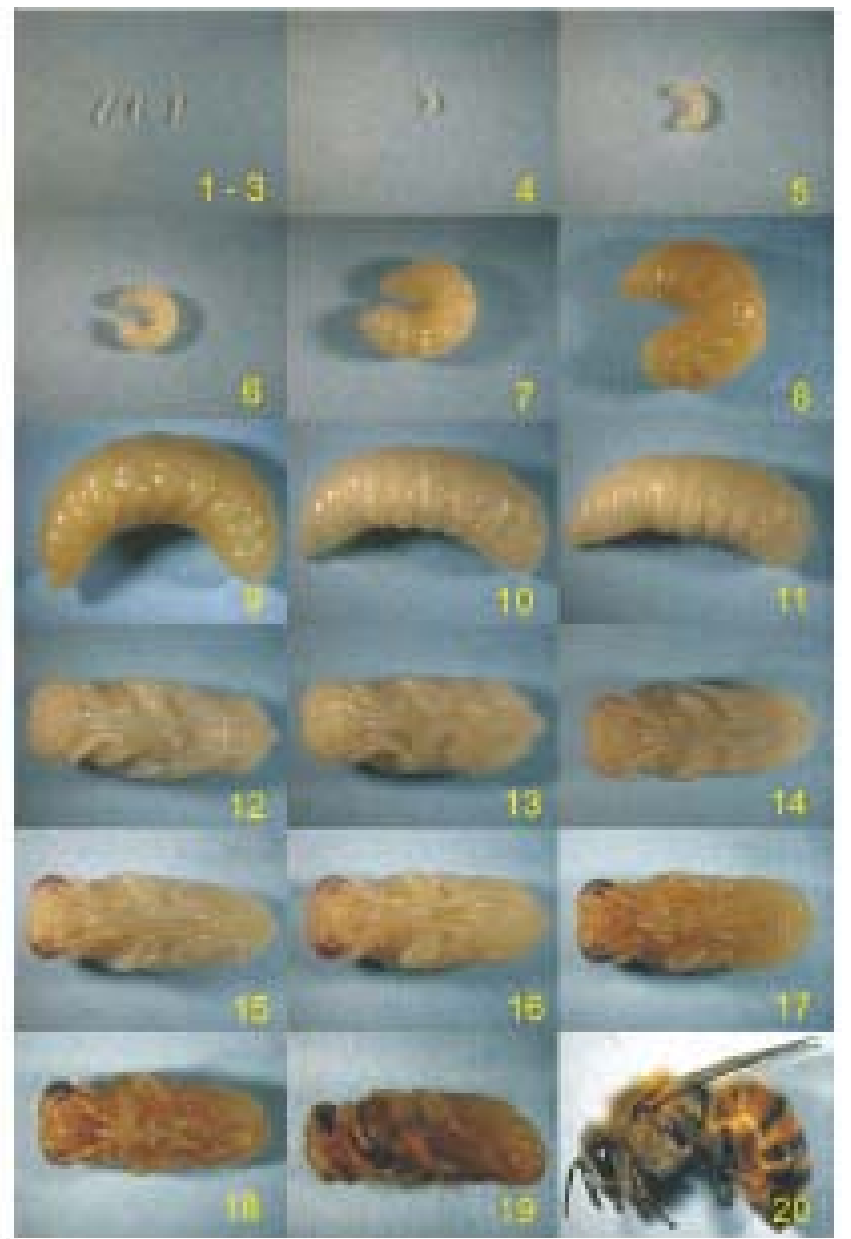

Figura 2: Estágios do desenvolvimento de operárias de Apis mellifera. Ambas as castas passam pelos mesmos estágios de desenvolvimento, desde ovo (13 ) até a emergência como adulta (20). . 


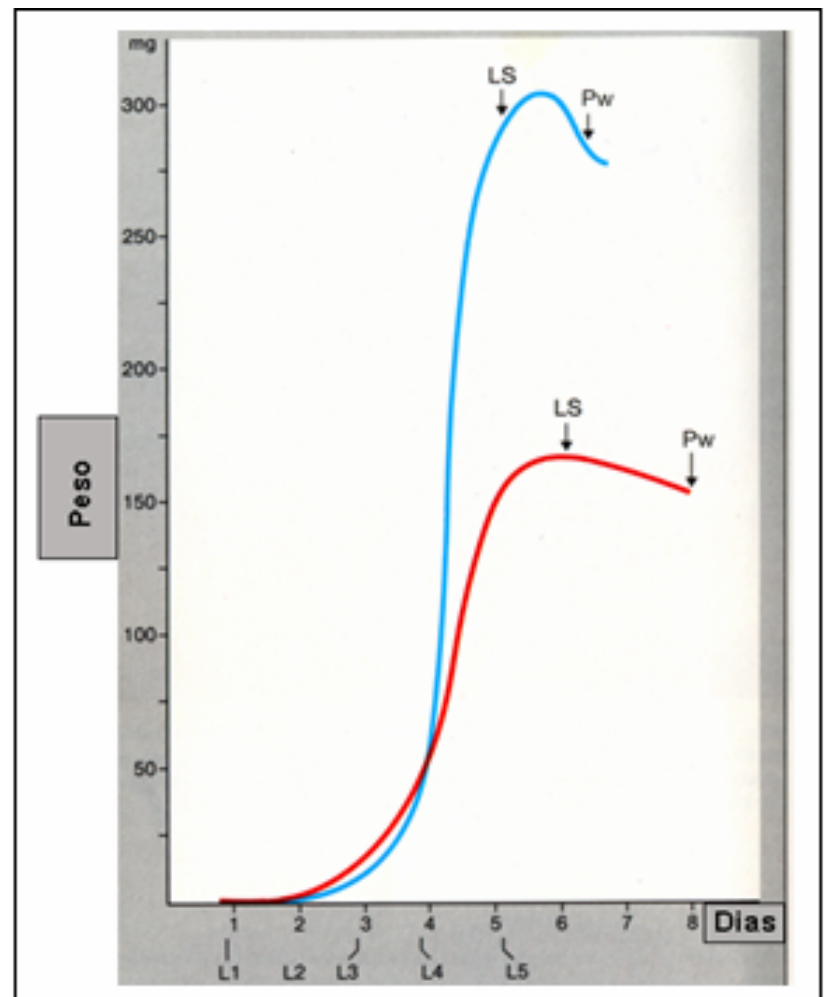

Figura 3: Curva de crescimento de rainhas (azul) e operárias (vermelho), demonstrando que mesmo após a tecelagem do casulo (LS) ainda ocorre o crescimento das larvas de rainhas. (Rembold 1988).

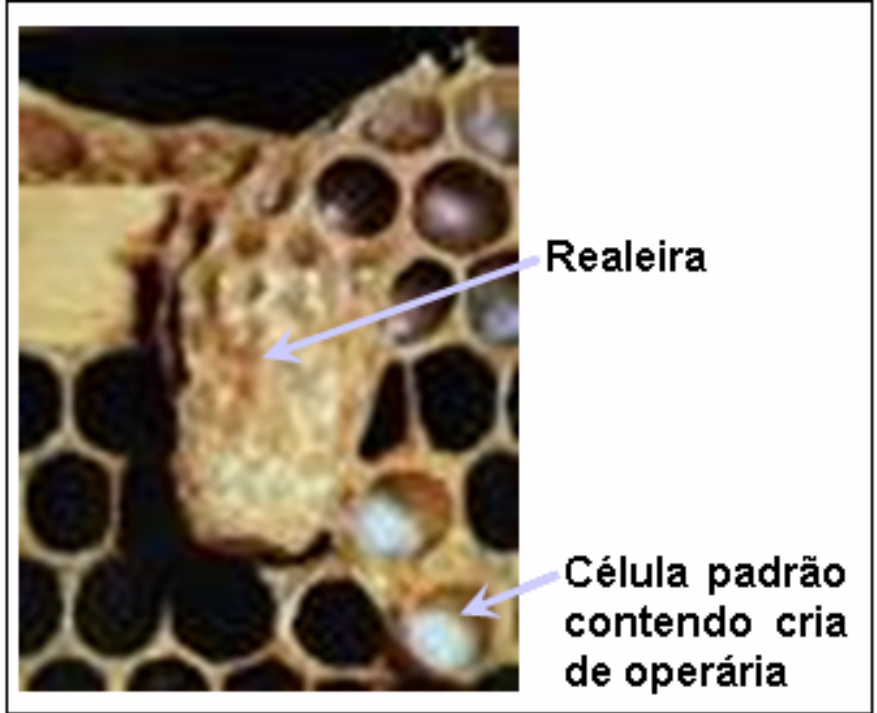

Figura 4: Região da colméia contendo uma célula disposta verticalmente onde ocorre o desenvolvimento de uma rainha. Esta, realeira,está rodeada por células padrão da colméia contendo larvas de operárias. 


\subsection{O Hormônio Juvenil e Ecdisteróides no processo de diferenciação de castas}

A expressão de fenótipos alternativos em insetos depende de fatores ambientais que se traduzem em respostas específicas do sistema endócrino, principalmente nos títulos de HJ e Ecd (para revisão ver, Dingle \& Winchell 1997; Hartfelder 2000a; Hartfelder 2000b; Hartfelder \& Emlen 2005),

Há muito tempo, atribui-se que a diferença entre as castas nos insetos sociais seja controlada pelo hormônio juvenil $(\mathrm{HJ})$. Experimentos feitos com aplicações ectópicas de $\mathrm{HJ}$ na década de setenta indicaram um proeminente papel para o $\mathrm{HJ}$ no desenvolvimento de castas e estabeleceram uma janela crítica para sua ação no quarto e no início do quinto instar (Rembold et al. 1974, Dietz et al. 1979 e Hartfelder \& Emlen 2005). Diferenças nos títulos de HJ foram verificadas através de radioimunoensaios (Figura 5) (Rembold 1987; Rachinsky et al.1990). As diferenças observadas entre os títulos do HJ em operárias e rainhas reforçam o papel desse hormônio como principal modulador da diferenciação de castas. Esta visão é compatível com o fato do hormônio juvenil funcionar em insetos como um importante fator regulador da embriogênese, no desenvolvimento larval e adulto, na metamorfose, reprodução, diapausa, migração, polimorfismo e metabolismo (Nijhout 1994, Roe \& Venkatesh 1990, De-Kort \& Granger 1996, Hammock 1985, Truman \& Riddiford 2002)

Comparado ao $\mathrm{HJ}$, existem poucos trabalhos a respeito do envolvimento dos ecdisteróides na diferenciação de castas. No entanto, análises dos títulos de ecdisteróides (Rachinsky et al. 1990) e da atividade da glândula protorácica (Hartfelder 1993) revelaram diferenças casta-específicas na fase larval, considerando-se portanto que outros hormônios além do HJ estejam envolvidos na regulação do desenvolvimento de castas. Além do mais, Hartfelder e colaboradores 
(1995) observaram um papel regulador dos ecdisteróides na síntese de algumas proteínas do ovário.

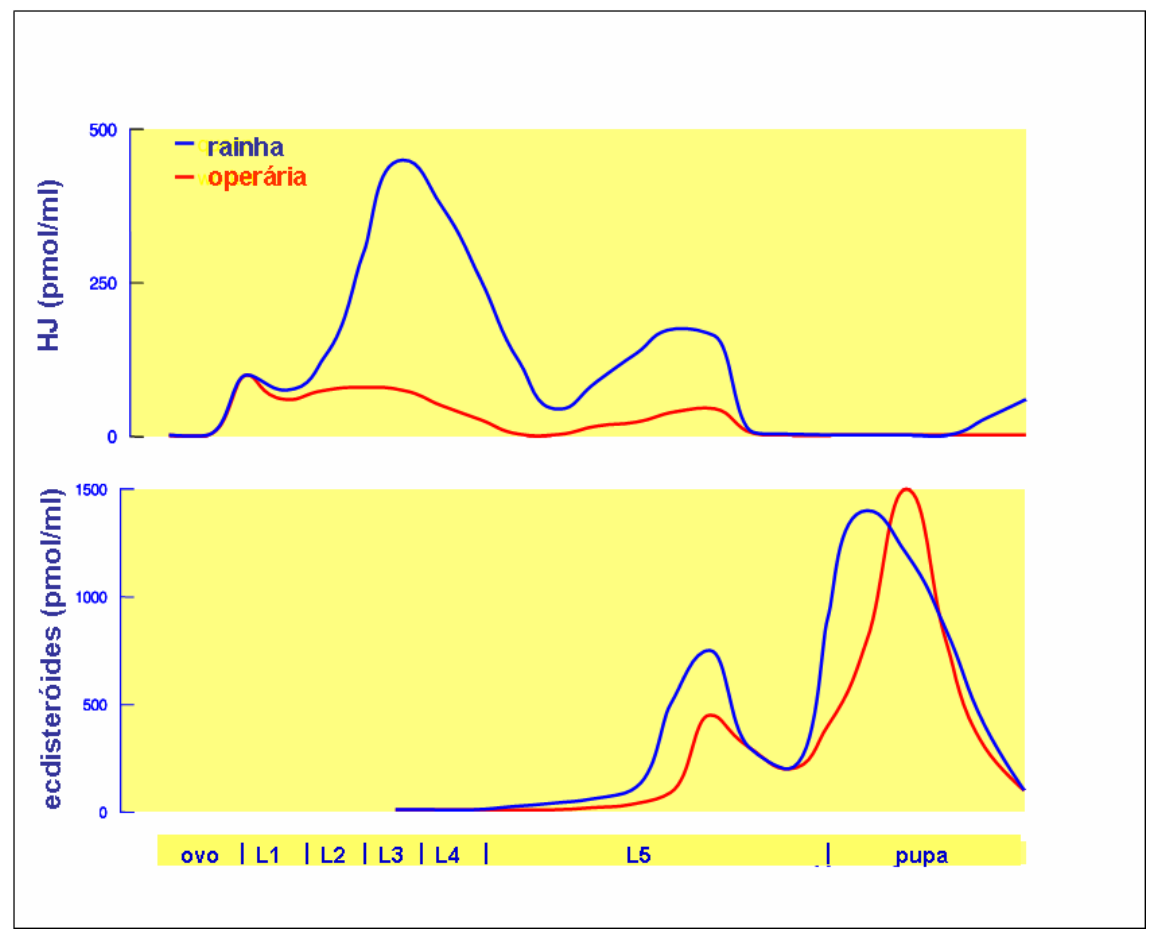

Figura 5: Título do HJ e ecdisteróides no desenvolvimento pré-imaginal de operárias e rainhas de Apis mellifera (Rembold 1987; Rachinsky et al. 1990).

\section{$1.4 \underline{\text { A via de sinalização insulina/receptor de insulina (IIS) }}$}

A origem de polifenismos (tanto genéticos como facultativos) tem sido atribuída à integração de mecanismos que atuam como interruptores (switch mechanisms) durante a morfogênese do respectivo organismo (Nijhout 1999). Há anos, considera-se que a expressão de fenótipos alternativos em insetos depende de fatores ambientais, os quais se traduzem em respostas específicas do sistema endócrino, principalmente nos títulos de $\mathrm{HJ}$ e de ecdisteróides (Ecd) (para revisão ver, Dingle \& Winchell 1997; Hartfelder 2000a; Hartfelder 2000b; Hartfelder \& Emlen 2005) . No entanto, nem todas as respostas gênicas observadas podem ser 
explicadas com relação a esses dois hormônios, o que sugere o envolvimento de outras vias de sinalização nas respostas da diferenciação de castas. Recentes descobertas, de conexões entre a sinalização por insulina e os clássicos hormônios de insetos (HJ e Ecd) na regulação da metamorfose em Drosophila (Colombani et al., 2005; Mirth et al., 2005), permitem sugerir uma ligação similar entre a expressão diferencial de genes relacionados ao metabolismo no desenvolvimento de castas com a sinalização endócrina que controla a metamorfose, Essa interação pode gerar alterações nos respectivos campos morfogenéticos das larvas (crescimento diferencial, morte celular programada, etc.).

O módulo de sinalização insulina-receptor de insulina (IIS) representa um dos mais antigos e mais bem conservados sistemas de sinalização no controle do crescimento de metazoários e está relacionado ao crescimento e proliferação celular, assim como na regulação do envelhecimento, metabolismo energético e fertilidade (Brogiolo et al. 2001; Oldham \& Hafen 2003; Stern 2003). De um modo geral, este módulo reage a alterações em concentrações de nutrientes, principalmente açucares e aminoácidos, e as traduz em uma resposta adequada de acordo com o tecido e fase da vida do organismo. A via de sinalização IIS, altamente conservada na evolução, constitui um exemplo de mecanismo regulador chave, o qual permite que os organismos se adaptem às mudanças de nutrientes (Puig \& Tijan 2005, 2006).

A insulina e os peptídeos similares à insulina são moléculas de sinalização peptídicas, que devido à sua composição protéica, necessitam de um receptor de membrana, o receptor de insulina (IR), para a propagação do sinal. Os receptores para insulina e fatores de crescimento como insulina (IGF) são receptores tirosinaquinase. Eles formam homodímeros de uma proteína com subunidades $\alpha$ 
(extracelular que se liga ao ligante insulina e/ou peptídeos como insulina) e $\beta$ (intracelular com atividade tirosina-quinase), que são unidas por pontes dissulfídicas (Ruan et al. 1995). Diferentes dos outros receptores tirosina-quinase, que são induzidos a se dimerizarem na presença do ligante, os receptores de insulina já existem na superfície celular em forma de dímeros mesmo antes de interação com o ligante(s). A ligação do ligante induz uma mudança conformacional que induz a ligação de ATP e à autofosforilação (Kim \& Accili 2002). A mudança conformacional, seguida da autofosforilação gera uma cascata de eventos que, entre outros, ativa a proteína substrato do receptor de insulina (IRS). resultando na ativação da quinase PI3K. Uma vez ativada, a quinase PI3K catalisa a fosforilação do inositol bi-fosfato $\left(\mathrm{PIP}_{2}\right)$, aumentando a produção de inositol tri-fosfato $\left(\mathrm{PIP}_{3}\right)$, o qual funciona como um segundo mensageiro ativando as quinases PDK e AKT (Radimerski et al. 2003; Goberdhan \& Wilson 2003; Puig \& Tijan 2005). A ativação da quinase AKT influencia a expressão gênica através de fatores de transcrição da família FOXO e dos genes supressores de tumor TSC. A fosforilação de FOXO leva à sua retenção no citoplasma e, portanto, uma diminuição na síntese de RNA de genes alvoespecíficos que afetam o ciclo celular (Alvarez et al. 2001) e apoptose (Brunet et al. 1999). A ativação de AKT inibe os genes supressores de tumor, do complexo tuberous escleroses (TSC), que agem juntamente com a via TOR (target of rapamycin) e com a quinase S6K na regulação do crescimento celular (Oldhan \& Hafen 2003). A ativação da sinalização via PDK, por sua vez, controla as atividades de várias outras quinases, incluindo AKT e S6K. (Goberdhan \& Wilson 2003). A quinase ribossomal S6K é um regulador upstream de TOR e da proteína efetora 4EBP1, e a integração dessas três proteínas controla o crescimento e o tamanho celular (Goberdhan \& Wilson 2003, Dufner \& Thomas 1999). 
De maneira geral, quando um inseto se alimenta, os nutrientes são absorvidos pelo intestino médio e, subsequentemente, circulam pela hemolinfa criando um pool nutricional. Os diferentes componentes desse pool nutricional, quando absorvidos pelas células, ativam vias sensíveis a esse tipo de informação, nas quais estão incluídas as vias IIS e TOR (Figura 6). Além de serem absorvidos por órgãos em crescimento, os componentes nutricionais podem também ser metabolizados por células do corpo gorduroso, o principal órgão de estoque de insetos e comparável ao fígado dos vertebrados. Esses nutrientes, por si só, não causam o crescimento diferencial de órgãos, mas afetam os títulos de diferentes hormônios e em decorrência destes, permitem o crescimento diferencial de órgãos (Stern \& Emlen 1999).

Estudos em insetos mostraram que a insulina e peptídeos similares à insulina são produzidos por células neurosecretoras do cérebro em resposta a alimentação (Wu \& Brown 2006). Os peptídeos insulínicos são compostos de duas cadeias peptídicas, A e B, unidas por pontes dissulfídricas. Estas duas cadeias são sintetizadas como parte de um produto gênico maior chamado de pré-proinsulina que está ligado a um peptídeo sinal. Durante a secreção da pré-proinsulina o peptídeo sinal é removido por clivagem proteolítica originando a proinsulina. A proinsulina é convertida no peptídeo final, insulina ou peptídeo como insulina, pela excisão proteolítica da cadeia C. O peptídeo final é constituído do peptídeo A-B ligados covalentemente por duas ligações dissulfídicas inter-cadeias e uma ligação dissulfídica intra-cadeia (Wu \& Brown 2006).

A sinalização através dos peptídeos como insulina, em particular a insulina, parece ser a via determinante do direcionamento de crescimento de órgãos, uma vez que o crescimento de órgãos responde quantitativamente ao nível de insulina 
em circulação produzida por essas células (Stern 2003). A via IIS age, portanto, no sentido de informar as células o quanto dos nutrientes disponíveis elas podem absorver e quanto de crescimento elas podem suportar (Stern, 2003), e assim define o tamanho final do corpo dos insetos.

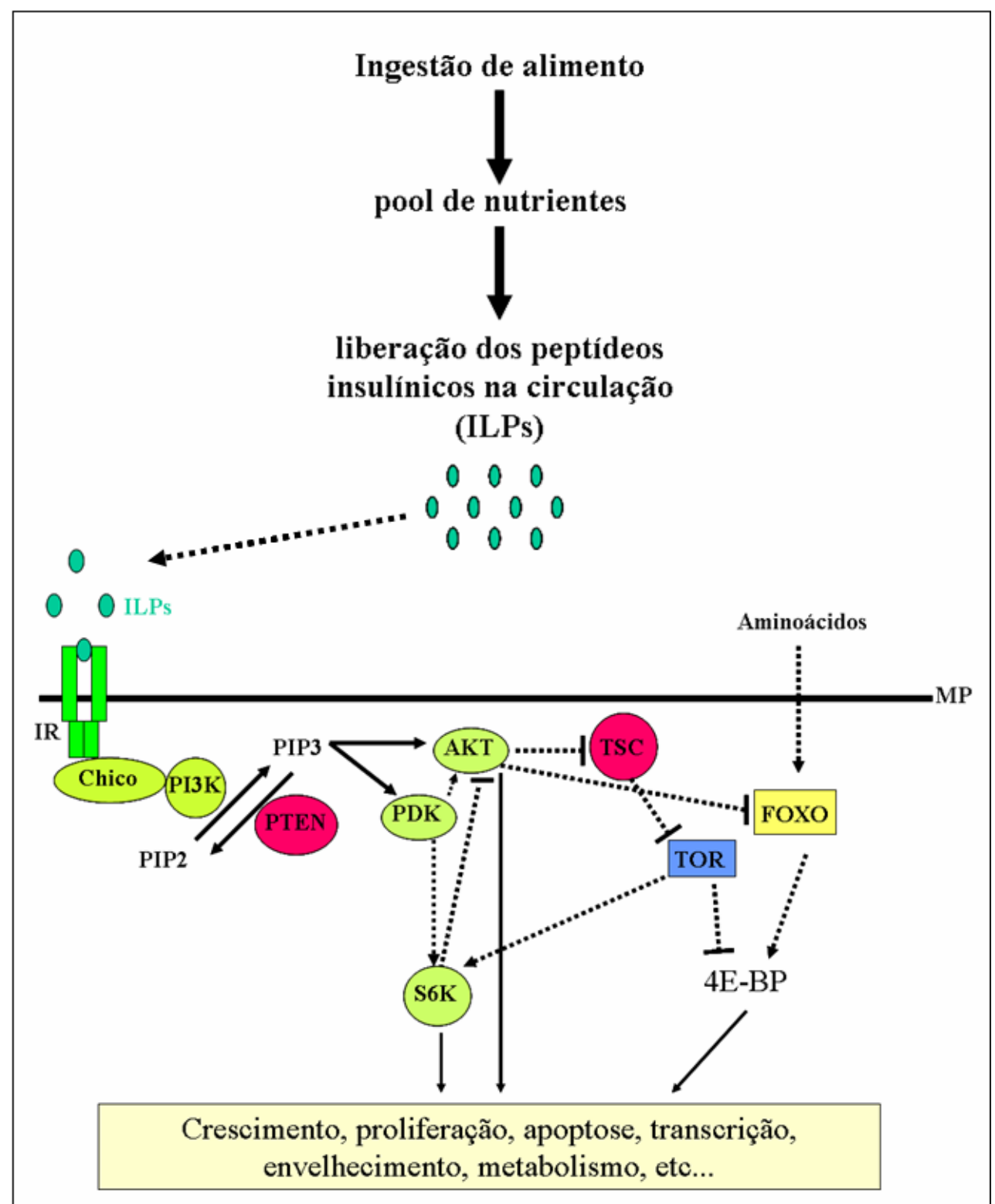

Figura 6: Esquema resumido da sinalização IIS baseado nas informações de Drosophila melanogaster. Em verde estão as moléculas que ativam outras moléculas, enquanto que em vermelho estão reguladores negativos da via. Em azul estão os alvos da via TOR, que constitui uma via paralela que converge com a via IIS formando a via IIS/TOR. Em amarelo estão os fatores de transcrição da família FOXO. A via foi esquematizada com base nos trabalhos de Dufner \& Thomas 1999, Alvarez et al. 2001, Goberdhan \& Wilson 2003, Oldham \& Hafen 2003; Stern 2003, Tatar et al. 2003, Bateman \& Neil 2004. 
Este módulo de sinalização exerce o mesmo papel em organismos filogeneticamente distintos e, portanto, pode representar um componente importante também na diferenciação das castas de abelhas e nas suas funções no ciclo de vida adulta. Estudos recentes, principalmente em Drosophila melanogaster, têm apontado a via receptor de insulina/TOR como módulo importante que ajusta taxas de crescimento às condições de nutrientes disponíveis ao organismo (Oldham \& Hafen 2003; Bateman \& Neil 2004). A via IIS/TOR regula o envelhecimento em nematóides, moscas e roedores (Tatar et al. 2003) e desempenha importante papel no controle da duração do crescimento, taxa de crescimento e indução da metamorfose (Mirth et al. 2005; Colombani et al. 2005). Tais dados podem direcionar também os estudos em Apis mellifera sobre as diferenças no tempo de desenvolvimento das larvas e na longevidade das abelhas adultas operárias e rainhas.

Há pouco tempo, a via de sinalização IIS/TOR vem ocupando lugar de destaque no cenário de determinação de castas como um dos principais componentes de sinalização envolvidos na diferenciação de castas em Apis mellifera. Wheeler e colaboradores (2006), estudando a via IIS como candidata para estreitar as relações entre a dieta e os sinais downstream da determinação de castas, verificaram a transcrição de dois peptídeos similares a insulina (AmILP-1 e AmILP-2). , sendo que a transcrição de $A m I L P-1$ foi maior no segundo instar larval de rainhas assim como a transcrição, em níveis mais altos, de um receptor de insulina (AmInR-2), enquanto nas operárias os níveis de transcrição dos genes para AmILP-1 e AmInR-2 foram baixos (Figura 7). Em um modelo, Seehuus e colaboradores (2006) sugeriram uma relação entre a via de sinalização IIS com as cascatas de sinalização do desenvolvimento, reprodução e longevidade ao longo da 
evolução dos insetos sociais. Colocando este modelo em teste, Patel e colaboradores (2007) evidenciaram que larvas destinadas a se tornarem rainhas apresentaram características de operárias quando expostas ao inibidor de TOR, a rapamicina, indicando assim um papel importante para a via de sinalização IIS/TOR no desenvolvimento das castas. Dessa maneira, ao que tudo indica, a via IIS pode estar fortemente relacionada a vários dos principais eventos determinantes das diferenças existentes entre as castas em Apis mellifera e em insetos sociais em geral (Seehuus et al. 2006; Wheeler et al. 2006; The Honeybee Genome Sequencing Consortium 2006; Patel et al.2007).

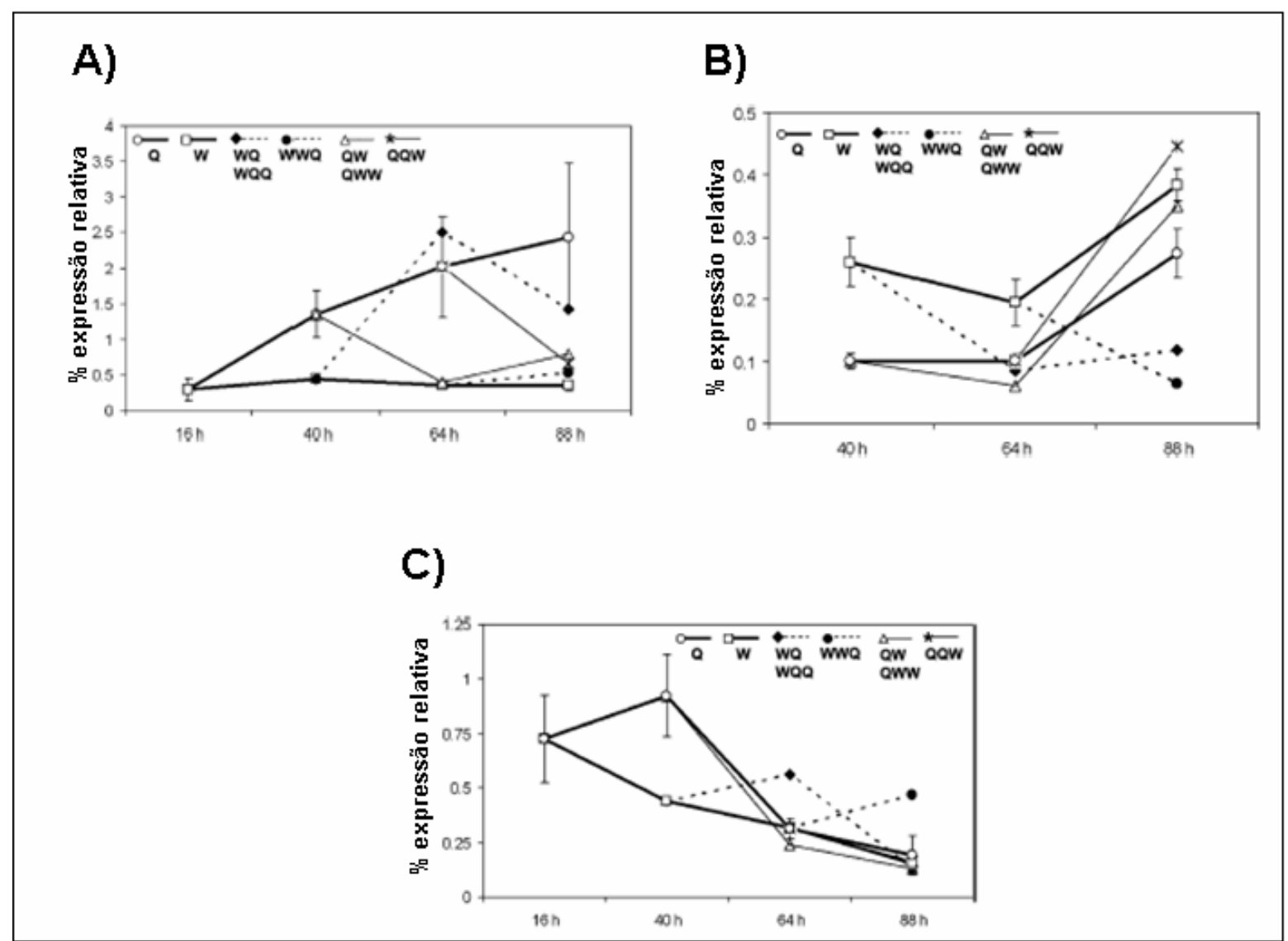

Figura 7: A)Expressão de AmILP-1, um peptídeo insulínico que é altamente expresso em larvas de rainhas. B) Expressão de $A m I L P-2$, um segundo peptídeo insulínico.C) Expressão de InR-2 em larvas de Apis mellifera (Wheeler et al. 2006). 


\section{Objetivos}

Estudos recentes em Apis mellifera e, principalmente, em Drosophila melanogaster, têm apontado a rede de sinalização insulínica (IIS) / TOR (target of rapamycin) como módulo importante que ajusta taxas de crescimento às condições de nutrientes disponíveis ao organismo. O módulo de sinalização IIS/TOR exerce o mesmo papel em organismos filogeneticamente bastante distintos podendo, portanto, representar um componente importante também na diferenciação das castas de abelhas e nas suas funções no ciclo de vida adulta.

Como objetivos específicos foram definidos os seguintes:

a) Identificar alguns dos principais genes constituintes da via IIS presentes no genoma de Apis mellifera utilizando a informação genômica recentemente disponível;

b) Validar pontos críticos da predição in silico dos ortólogos do receptor de insulina em Apis mellifera (AmIR) por clonagem e sequenciamento de fragmentos amplificados;

c) Investigar por RT-PCR quantitativa e semiquantitativa o perfíl temporal da expressão de componentes chaves da via IIS no desenvolvimento larval, specialmente dos receptores de insulina;

d) Investigar a possível interação entre os hormônios morfogenéticos (HJ e ecdisteróides) com a via IIS. 


\section{Material e métodos}

\subsection{Abelhas}

O estudo foi realizado utilizando-se diferentes núcleos de abelhas africanizadas Apis mellifera do apiário experimental do Departamento de Genética da Faculdade de Medicina de Ribeirão Preto - Universidade de São Paulo (USP).

Tanto para a obtenção de operárias quanto de rainhas foi realizado um procedimento inicial com a finalidade de controlar as idades larvais. Neste, a rainha foi aprisionada por cerca de 6 horas, sob uma tela de exclusão, em uma região do favo adequada para postura. Este procedimento possibilitou a obtenção de larvas e pupas com aproximadamente a mesma idade.

\subsubsection{Operárias}

Para a coleta de operárias de Apis mellifera nos estágios de desenvolvimento pós-embrionário, favos contendo as crias nos diferentes estágios larvais $\left(L_{2}, L_{3}, L_{4}\right.$, $L_{5} F_{1}, L_{5} F_{2}, L_{5} F_{3}, L_{5} S_{1}, L_{5} S_{2}$ e $L_{5} S_{3}$ ), pré-pupais e pupais foram selecionados e levados a uma sala própria, onde as larvas, pré-pupas e pupas foram retiradas das células com o auxílio de uma colher suíça ou pinça e colocadas sobre placas de Petri forradas com papel de filtro. As larvas foram classificadas nos diferentes estágios larvais de acordo com o seu peso corporal e o tamanho da sua cápsula cefálica (Michellete \& Soares 1993). As pré-pupas foram classificadas de acordo com características morfológicas de cada fase como: a formação da constrição torácica, a falta de movimentação, a posição da larva na célula entre outras, e as pupas foram classificadas de acordo com a pigmentação dos olhos e cutícula (Michellete \& Soares 1993). 
Após a identificação de cada estágio as operárias foram colocadas em tubos estéreis de $2 \mathrm{ml}$ contendo $1 \mathrm{ml}$ de $\mathrm{TRI} / \mathrm{B}{ }^{\circledR}$ (Invitrogen) onde foram homogeneizadas com o auxílio de uma ponteira de micro-pipeta e guardadas no freezer $-80^{\circ} \mathrm{C}$ para a extração de RNA (Item 3.3). Do estágio L2 foram colocadas aproximadamente vinte larvas por tubo; do estágio L3 por volta de dez larvas por tubo; do estágio L4 cerca de cinco larvas por tubo e do estágio L5 até pupa de olho escuro, dois indivíduos por tubo.

A fim de obter abelhas operárias adultas recém emergidas para o experimento com diferentes tipos de alimentação (Item 3.4) e para a obtenção de operárias adultas com diferentes idades, um quadro com abelhas em vias de emergirem foi mantido em uma gaiola na incubadora por um período de 12 a 16 horas e as abelhas que emergiram durante esse tempo foram coletadas. Estas abelhas foram marcadas com tinta, inodora e atóxica, na região dorsal do tórax e devolvidas na colméia ou transferidas para caixas em experimentos com diferentes tipos da alimentação. As abelhas mantidas sob diferentes dietas foram coletadas entre 1 e 11 dias de vida adulta, enquanto que as mantidas na colméia foram coletadas até 24 dias. As abelhas foram anestesiadas sob gelo, tiveram seus intestinos retirados e, então, foram colocadas em tubos contendo $1 \mathrm{ml}$ de $\mathrm{TRIzol}{ }^{\circledR}$ para extração de RNA (Item 3.3).

\subsubsection{Rainhas}

As rainhas foram obtidas por transferência para realeiras artificiais de larvas $L_{1}$, obtidas por postura controlada. As larvas foram transferidas com o auxílio de uma colher suíça para realeiras contendo geléia real e, posteriormente, levadas para colméias de recria. Uma colméia de recria corresponde a duas caixas do tipo 
Langstroth dispostas uma sobre a outra e separadas por uma tela excluídora da rainha, que impede a passagem da mesma para o compartimento superior onde são introduzidas as barras contendo as realeiras. As fases de desenvolvimento larval, pré-pupal e pupal foram classificadas da mesma maneira como as operárias (Item 3.1.1), mas seguindo a descrição de Rembold e colaboradores (1980).

Após a identificação de cada estágio as rainhas foram colocadas em tubos estéreis de $2 \mathrm{ml}$ contendo $1 \mathrm{ml}$ de $\mathrm{TRI} \mathrm{Ro}{ }^{\circledR}$ (Invitrogen) onde foram homogeneizadas com o auxílio de uma ponteira, estéril, de micro-pipeta e guardadas no freezer $-80^{\circ} \mathrm{C}$ para a extração de RNA. Do estágio L3 foram colocadas aproximadamente dez larvas por tubo, do estágio L4 cerca de cinco larvas por tubo e do estágio L5 até pupa de olho escuro dois indivíduos por tubo.

\subsection{Dissecção do material biológico}

Para obtenção dos ovários, larvas de rainhas e operárias em diferentes estágios (L4, L5F3, L5S1, L5S3 e PP1) obtidas de acordo com os itens 3.1, foram dissecadas em solução salina $0,9 \%$ estéril. As mesmas foram mergulhadas em solução salina sob uma placa de Petri de vidro, preenchida com parafina sólida, e fixadas com alfinete entomológico de maneira que a região dorsal ficou para cima. Com o auxílio de pinças de ponta fina as abelhas foram abertas em extensão anteroposterior, na região do abdômen, e os ovários de operárias e rainhas foram retirados, colocados em $500 \mu$ de reagente TRIzol ${ }^{\circledR}$ (Invitrogen) e estocados no freezer $\left(-80^{\circ} \mathrm{C}\right)$ até o momento da extração do RNA. Todos os materiais utilizados foram lavados e esterilizados. Os números de pares de ovários coletados para cada fase variaram entre oito e doze pares. 


\subsection{Extração do RNA total e síntese do cDNA}

Os materiais biológicos mantidos em TRIzol $\left(\right.$ Invitrogen) no freezer $-80^{\circ} \mathrm{C}$ (corpo inteiro e ovários de rainhas e operárias) para extração do RNA foram retirados e deixados na bancada para descongelarem. Posteriormente, os mesmos foram centrifugados por 10 minutos à $4^{\circ} \mathrm{C}$ e $12.000 \mathrm{~g}$ e os procedimentos de extração seguiram o protocolo do fabricante para a extração com TRIzol® (Invitrogen). O RNA obtido foi ressuspendido em água deionizada tratada com dietilpirocarbonato (DEPC) $0,1 \%$ para evitar degradação. A concentração e qualidade das amostras foram estimadas em espectrofotômetro. As leituras foram feitas a $260 \mathrm{~nm}$ e $280 \mathrm{~nm}$, considerando-se RNA de pureza adequada quando a relação 260/280nm atingiu valores entre $1,4-1,7$

Anteriormente à síntese do cDNA (DNA complementar ao RNA mensageiro), o RNA foi tratado com DNase (RQ1 Rnase-Free Dnase, Promega) por 1 hora a $37^{\circ} \mathrm{C}$ e em seguida a $65^{\circ} \mathrm{C}$ por 15 minutos, para desnaturar a enzima. Para obter a primeira fita de cDNA foram utilizados diferentes quantidades de RNA total: para as amostras de corpo inteiro de larvas de operárias e rainhas foram utilizados $2 \mu \mathrm{g}$, para as amostras de ovários de operárias e rainhas utilizamos $0,9 \mu \mathrm{g}$, para as amostras de larvas de operárias tratadas com PPN utilizamos $1 \mu \mathrm{g}$, para as amostras de operárias adultas e cultivadas em diferentes tipos de alimentos utilizamos $2,5 \mu \mathrm{g}$. A primeira fita de cDNA foi obtida em protocolo de síntese que utiliza Superscript II (Invitrogen) e Oligo (dT) ${ }_{12-18}$ (Invitrogen), seguindo instruções do fabricante. Por este método, apenas a primeira fita do cDNA é sintetizada através de transcrição reversa. A segunda fita é gerada por PCR com o uso de primers específicos. 
As bibliotecas de cDNA,originadas a partir do RNA total foram normalizadas para os genes da actina de Apis mellifera (número de acesso ao Official_Gen_Set GB17681). Os primers utilizados para a amplificação da actina foram: ACT-foward (5'- TGC CAA CAC TGT CCT TTC TG- 3') e ACT-reverse (5'- AGA ATT GAC CCA CCA ATC CA-3') e a temperatura de anelamento foi $60^{\circ} \mathrm{C}$ (Nascimento et al, 2004). O produto de amplificação de 154 pb da actina foi visualizado em gel de agarose $1,2 \%$ e corado com brometo de etídio. Além do gene para actina, as amostras foram normalizadas, também, para o gene codificador da proteína ribossomal RP49 (GenBank accession number AF441189) Os primers utilizados foram RP49-F (CGT CAT ATG TTG CCA ACT GGT) e RP49-R (TTG AGC ACG TTC AAC AAT GG). O RP49 foi utilizado como normalizador das reações de PCR quantitativa (Item 3.7.1) enquanto que a actina foi utilizada como nomalizador nas reações de PCR semiquantitativa (Item 3.7.2).

\subsection{Operárias recém emergidas mantidas sob diferentes tipos de alimentação}

Para realização dos experimentos com diferentes tipos de alimentação foram coletados amostras de geléia real, bee bread e mel. A geléia real foi coletada com o auxílio de uma colher suiça das realeiras utilizadas para a criação de rainhas, pois as operárias nutridoras depositam continuamente geléia real em realeiras contendo larvas, e armazenada em tubos de $2 \mathrm{ml}$. O bee bread utilizado era constituído de $30 \%$ de pólen, que foi retirado diretamente dos favos com o auxílio de uma colher suíça, e 70\% de xarope (açúcar dissolvido em água na concentração de 1:1 (p:v)). O mel utilizado foi mel puro de Apis mellifera comprado comercialmente. Todos os alimentos, com exceção do mel, que ficou à temperatura ambiente, foram estocados na geladeira e retirados minutos antes da alimentação. 
Utilizamos três caixas $(10 \times 12 \times 5 \mathrm{~cm})$ com cerca de 30 abelhas operárias em cada uma, que foram mantidas sobre as respectivas dietas a partir do segundo dia da introdução. No primeiro dia de adulta, as operárias recém emergidas receberam como alimento suplementar um alimentador com geléia real, que de acordo com observações empíricas em nosso laboratório é essencial para ativação de algumas proteases no intestino de abelhas jovens. O abastecimento dos alimentadores e a limpeza das caixas, fezes e abelhas mortas, ocorreram diariamente. Além disso, cada caixa recebeu um alimentador com água para consumo ad libitum. A Figura 8, abaixo, representa o modelo da caixa utilizada no experimento. Como controle, abelhas recém emergidas foram marcadas e retornadas à colméia de origem.

As abelhas mantidas nas caixas sob diferentes dietas foram coletadas entre 1 e 11 dias, anestesiadas sob gelo, tiveram seus intestinos retirados e, então, foram colocadas em tubos contendo $1 \mathrm{ml}$ de TRIzol® para extração de RNA (Item 3.3).

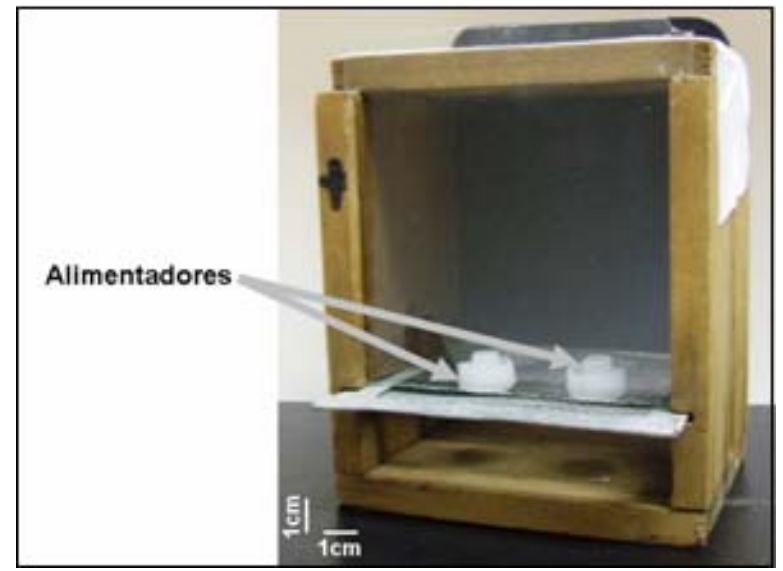

Figura 8: Modelo de caixa utilizado para manutenção das abelhas operárias em diferentes tipos de alimentação.

\subsection{Tratamento com análogo do hormônio juvenil, pyriproxifen (PPN)}

Foram aplicados $0,5 \mu \mathrm{l}$ de solução PPN (10 mg de PPN por $\mu \mathrm{l}$ de hexano) com o auxílio de uma micropipeta em larvas operárias de 3 dias, diretamente no 
favo. Os respectivos alvéolos foram mapeados com a utilização de uma folha de acetato e canetas de retro-projetor. Após mapear as áreas tratadas com PPN e os controles [solvente (hexano) e sem tratamento] o quadro contendo as larvas foi

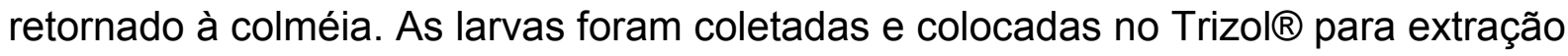
do RNA (Item 3.3) 2, 6 e 24 horas após o tratamento.

\subsection{Desenho de primers}

Primers específicos para genes de interesse na sinalização pela via IIS foram desenhados utilizando-se de dois programas diferentes, a fim de garantir uma boa qualidade dos mesmos. Os programas utilizados foram o Primer3 disponível na rede http://frodo.wi.mit.edu/cgi-bin/primer3/primer3 www.cgi e o programa Gene Runner versão 3.05 .

Os primers foram desenhados sob o genoma de Apis mellifera versão 3.0 e 4.0 disponíveis nos sites http://zulu.fmrp.usp.br/beelab/beelab/index html e http://www.hgsc.bcm.tmc.edu/projects/honeybee/ a partir das predições disponíveis no banco

de dados

Official_Gene_Set

(http://zulu.fmrp.usp.br/beelab/beelab/index html)

Foram desenhados primers para os genes codificadores do receptor de insulina InR1 (número de acesso no Official_Gene_Set GB15492) e InR2 (número de acesso no Official_Gene_Set GB18331); para o gene chico, codificador do substrato para o receptor de insulina (número de acesso no Official_Gene_Set GB11037); para a quinase da proteína ribossomal S6K (número de acesso no Official_Gene_Set GB19390), para o gene codificador de um alvo para rapamicina, TOR (número de acesso no Official_Gene_Set GB11213) e, por ultimo, para a 
proteína Tuberous sclerosis -1 (Tsc1) (número de acesso no Official_Gene_Set GB12676-PA). Os primers desenhados seguem na tabela abaixo:

Tabela 1: Primers específicos para análise de expressão de genes integrantes da via IIS, identificados com os seus respectivos números de acesso no banco de dados Official_Gene_Set

\begin{tabular}{|c|c|c|c|c|}
\hline Gene & $\begin{array}{l}N^{\circ} . \text { de acesso } \\
\text { Official_Gene_Set }\end{array}$ & $\begin{array}{c}\text { Nome do } \\
\text { primer }\end{array}$ & Seqüência 5'- 3' & $\begin{array}{c}\text { Temperatura } \\
\text { de } \\
\text { anelamento }\end{array}$ \\
\hline \multirow[t]{2}{*}{ InR1 } & GB15492 & InR1-F & GGA TCT GGT GTG GGA CAG TT & $60^{\circ} \mathrm{C}$ \\
\hline & & $\ln \mathrm{R} 1-\mathrm{R}$ & ATC CCC ACG TCG AGT ATC TG & $60^{\circ} \mathrm{C}$ \\
\hline \multirow[t]{4}{*}{ InR2 } & GB18331 & IR3-F & CCA ACT CCT TCA CGA TGT TC & $60^{\circ} \mathrm{C}$ \\
\hline & & IR3-R & GTG TGC GAG AAG CAC TGT C & $60^{\circ} \mathrm{C}$ \\
\hline & & IR2-F & CGT TGG TCA TCA TGG AGT TG & $52^{\circ} \mathrm{C}$ \\
\hline & & IR2-R & TCC GGG CTG TGA TAG AAG C & $52^{\circ} \mathrm{C}$ \\
\hline \multirow[t]{2}{*}{ Chico } & GB11037 & Chico-F & CAT TCA TGT ATC GTC CTC TGC & $60^{\circ} \mathrm{C}$ \\
\hline & & Chico-R & GCA TCT GCA ATA GTA CGA TCG & $60^{\circ} \mathrm{C}$ \\
\hline \multirow[t]{2}{*}{ TSC-1 } & GB12676 & TSC1-F & CGA CCA TCT ACA CCG ATT CC & $60^{\circ} \mathrm{C}$ \\
\hline & & TSC1-R & GTC CCA GAA TGC GTA CAA GC & $60^{\circ} \mathrm{C}$ \\
\hline \multirow[t]{2}{*}{ TOR } & GB11213 & TOR-F & GGC TAT ATC CTT GGT CTT GG & $60^{\circ} \mathrm{C}$ \\
\hline & & TOR-R & GCT CTG CTC TTG ATT ACT GC & $60^{\circ} \mathrm{C}$ \\
\hline \multirow[t]{2}{*}{ S6K } & GB19390 & S6K-F & GAA AGG GTG GTT ATG GCA AG & $60^{\circ} \mathrm{C}$ \\
\hline & & S6K-R & GGT CTA CGA TGA AAG GAT GC & $60^{\circ} \mathrm{C}$ \\
\hline
\end{tabular}

\subsection{Reação em cadeia da polimerase (PCR)}

As bibliotecas de cDNA sintetizadas a partir do RNA (Item 3.3) foram utilizadas como moldes para as reações de PCR quantitativas (Real Time) e semiquantitativas.

\subsubsection{PCR quantitativa (Real Time PCR)}

Para a reação de amplificação em tempo real foi utilizado a metodologia SYBR $\circledast$ Green no sistema Real Time PCR 7500 (Applied Biosystems). Em cada reação utilizamos $10 \mu \mathrm{l}$ de SYBR Green (Applied Biosystems), 0,5 $\mu$ l de cada primer

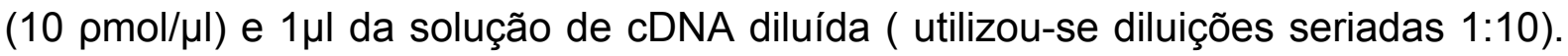
Os valores de quantificação relativa foram calculados utilizando-se a metodologia de Pfaffl (2001).

Para amplificação dos transcritos dos genes codificando os receptores de insulina em Apis mellifera foram utilizados os primers InR1-F e InR1-R para o gene 
InR1 (GB15492) (Item 3.6) e para o gene InR2 (GB18331) utilizamos os primers desenhados por Wheeler e colaboradores (2006), InR2-F (5' GGG AAG AAC ATC GTG AAG GA 3') e InR2-R (5' CAT CAC GAG CAG CGT GTA CT 3'). As amplificações ocorreram conforme protocolo padrão do sistema Real Time PCR 7500 (Applied Biosystems). A eficiência dos primers foi verificada por RT-PCR quantitativa utilizando-se diluições seriadas, de cDNA 1:10, para cada par de primers. Os valores de regressão linear foram conferidos, sendo considerados eficientes os primers com coeficiente de correlação $r>0,95$ e com o valor de $E$ próximo de $2\left[E=10^{(-1 / \text { slope })}\right]$ (Pfaffl 2001). Para a confecção dos gráficos com os resultados da quantificação relativa entre os genes alvos e o normalizador RP49 foram calculados os valores da taxa $=2^{-\Delta \Delta C T}($ Pfaffl 2001).

\subsubsection{PCR semi-quantitativa}

Para amplificação dos transcritos por PCR semi-quantitativa utilizamos as soluções Eppendorf Master Mix (2,5X) (Eppendorf) e Platinum® Taq DNA Polymerase High Fidelity (invitrogen) e os pares de primers: InR-1, IR2, IR3, Chico, TSC-1, TOR, S6K (Tabela 1).

A reação para a solução de master mix foi:

- Água deionizada e autoclavada $\quad 12 \mu \mathrm{l}$

- Master Mix (2,5X; Eppendorf) $\quad 10 \mu \mathrm{l}$

- Primer foward $(10 \mu \mathrm{M})$

- Primer reverse $(10 \mu \mathrm{M}) \quad 1 \mu \mathrm{l}$

- CDNA $\quad 1 \mu \mathrm{l}$

$25 \mu l$ ( volume final) 
A reação para Platinum ${ }^{\circledR}$ Taq DNA Polymerase High Fidelity (invitrogen) foi:

- Tampão High Fidelity 10X 2,5 $\quad 2$

- dNTP mix 10mM $\quad 0,5 \mu l$

$-\mathrm{MgSO}_{4} 50 \mathrm{mM}$

- Primer-F $\quad 1 \mu l$

- Primer-R $\quad 1 \mu \mathrm{l}$

- Água deionizada e autoclavada $\quad 17,85 \mu l$

- Platinum ${ }^{\circledR}$ Taq High Fidelity $\quad 0,015 \mu l$

- cDNA $\quad 1 \mu \mathrm{l}$

$25 \mu l$ (volume final)

A máquina de PCR utilizada foi um termociclador PTC*200 (MJ Research) e o programa de amplificação foi:

- 1) $95^{\circ}$ por 5 minutos

- 2) $95^{\circ}$ por 30 segundos

- 3) temperatura de anelamento do primer ( Item 3.6) por 30 segundos

- 4) $72^{\circ} \mathrm{C}$ por 1 minuto

- 5) go to 2 (entre 29 e 39 vezes)

- 6) $72^{\circ} \mathrm{C}$ por 10 minutos

- 7) $4^{\circ} \mathrm{C}$ por tempo indeterminado

Os produtos de amplificação foram submetidos à eletroforese em gel de agarose 1,2\% em tampão 1X TBE (89mM Tris base, $89 \mathrm{mM}$ ácido bórico, $2 \mathrm{mM}$ EDTA, pH 8,0) e corado com uma solução de brometo de etídio, $\operatorname{EtBr}(0,5 \mu l / m l$ de gel). 


\subsection{Preparo das células quimiocompetentes}

Células competentes foram obtidas a partir de células bacterianas E.coli, da linhagem $\mathrm{DH} 5 \alpha$, seguindo o protocolo do manual de laboratório de Sambrook et al. (1989). Foram inoculados $5 \mathrm{ml}$ de meio LB (Luria Bertani) com células $\mathrm{DH} 5 \alpha\left(-80^{\circ}\right)$ e crescidas à $37^{\circ} \mathrm{C}$ sob agitação (250 rpm) durante a noite. Para expansão, uma alíquota de $50 \mu$ do cultivo líquido foi inoculado em $50 \mathrm{ml}$ de meio LB e deixado para crescer à $37^{\circ} \mathrm{C}$ sob agitação de $250 \mathrm{rpm}$, até atingir uma DO (595nm) de aproximadamente $0,3-0,4$. Após atingir a densidade ótica desejada a amostra foi aliquotada em tubos estéreis Corex e centrifugada a $6000 \mathrm{rpm}$ por 5 minutos à $4^{\circ} \mathrm{C}$. O sobrenadante foi retirado e o precipitado de um dos tubos ressuspendido em $5 \mathrm{ml}$ de $\mathrm{CaCl}_{2}$ 0,1M. Após ressuspender o primeiro tubo, o conteúdo foi passado para o próximo tubo, para ressuspendê-lo, e assim por diante até o ultimo tubo. Após ressuspender todos os precipitados, a amostra foi centrifugada a 6000rpm por 5 minutos à $4^{\circ} \mathrm{C}$. O sobrenadante foi eliminado e o precipitado ressuspendido com $5 \mathrm{ml}$ de $\mathrm{CaCl}_{2} \quad 0,1 \mathrm{M}$ contendo $15 \%$ de glicerol. A solução contendo as células competentes foi aliquotada em tubos de crioproteção $(250 \mu \mathrm{l})$ e congelada à $-80^{\circ} \mathrm{C}$.

Todas as vidrarias e soluções utilizadas foram auto-clavadas à $120^{\circ} \mathrm{C}$ por 45 minutos.

\subsection{Clonagem e sequenciamento}

Os fragmentos obtidos por amplificação com os pares de primers IR2, IR3, InR-1, Chico e S6K. Foram analisadas em gel de agarose 1,2\%. As bandas foram retiradas do gel e o DNA purificado com a utilização do kit NúcleoSpin ${ }^{\circledR}$ (MachereyNagel) ou o kit Perfectprep $®$ Gel Cleanup (Eppendorf) seguindo o protocolo do 
respectivo fabricante. A inserção em vetor pGEM-T (kit pGEM-T Easy Vector ${ }^{\circ}$, Promega) ou em vetor TOPO ${ }^{\circledR}$ (kit TOPO TA Cloning ${ }^{\circledR}$, Invitrogen) também foi feita de acordo com o protocolo de cada fabricante. A transformação das células competentes ocorreu por choque térmico (30 minutos no gelo - um minuto à $42^{\circ} \mathrm{C}$ gelo). Após a transformação as células foram incubadas à $37^{\circ} \mathrm{C}$ por cerca de duas horas em meio líquido LB sem penicilina. Após a incubação, as células foram plaqueadas em meio de cultura LB-ágar (1,5\%) contendo Ampicilina (USB;

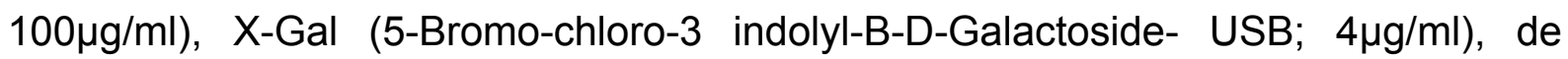
maneira que apenas as células transformadas se desenvolveram no meio. As colônias transformadas contendo os fragmentos (colônias brancas) foram selecionadas e cultivadas, em tubos Falcon, overnight à $37^{\circ} \mathrm{C}$, sob agitação, em meio LB líquido com ampicilina $(40 \mathrm{mg} / \mathrm{ml})$.

Os vetores contendo os fragmentos foram retirados das células competentes utilizando-se o kit Fast Plasmid Mini ${ }^{\circledR}$ (Eppendorf) ou o kit GeneJET ${ }^{\mathrm{TM}}$ Plasmid Miniprep Kit (Fermentas) seguindo o protocolo de cada fabricante. Para verificar a presença do inserto o plasmídio foi clivado com a enzima EcoRI (digestão de $8 \mu$ le DNA por 2 horas à $37^{\circ} \mathrm{C}$ ) e analisado em gel de agarose $1,2 \%$ com tampão $1 \times$ TBE, corado com brometo de etídio.

Os clones que possuíam o inserto foram submetidos à reação de PCR com o mix Big dye terminator (Perkin Elmer) utilizando os primers universais M13 foward (5' CGA CGT TGT AAA ACG ACG GCC AGT 3') ou M13 reverse.(5' CAG GAA ACA GCT ATG AC 3'), seguindo o método de Sanger. O DNA resultante da PCR foi transferido para microtubos de $1,5 \mathrm{ml}$ e precipitado por adição de $40 \mu \mathrm{l}$ de isopropanol $75 \%$ para cada volume de $10 \mu$ l de reação. Após uma breve agitação os microtubos foram deixados 15 minutos à temperatura ambiente e em seguida foram 
centrifugados à temperatura ambiente por 20 minutos a $14.000 \mathrm{rpm}$. Os sobrenadantes foram retirados e aos precipitados foram adicionados $250 \mu$ de isopropanol $75 \%$. As amostras foram agitadas rapidamente e centrifugadas por 5 minutos à $14.000 \mathrm{rpm}$. Os sobrenadantes foram retirados e todo o álcool foi evaporado em banho seco à $59^{\circ} \mathrm{C}$. Após secar por completo o DNA foi ressuspendido em $12 \mu$ da solução Template Suppression Reagent (TSR) (ABI PRISM ${ }^{\circledR}$, Applied Biosciences). As amostras foram transferidas para tubos de sequenciamento. O seqüenciador utilizado foi um seqüenciador de capilar $A B I 310$ (Applied Biosciences). As seqüências obtidas foram submetidas a análises tipo BLAST contra os bancos de dados GenBank (http://www.ncbi.nlm.nih.gov/) e Official_Gene_Set (http://zulu.fmrp.usp.br/beelab/beelab/index html).

\subsection{Análise in sílico}

O sequenciamento recente do genoma da abelha (http://hgsc.bcm.tmc.edu/projects/honeybee/), a disponibilidade de grande número de etiquetas de seqüências expressas e a disponibilidade de seqüências de outros organismos em bancos de dados (http://www.ncbi.nlm.nih.gov/) torna a análise computacional (in sílico) uma poderosa ferramenta no avanço das pesquisas com Apis mellifera. A fim de buscar genes codificadores de receptores de insulina de diversos organismos foi feito uma busca no banco de dados NCBI (http://www.ncbi.nlm.nih.gov/) e as seqüências obtidas serviram de entrada para buscas TBLASTN contra genoma de Apis mellifera (assembly Amel 3.0 e 4.0) e genes preditos de Apis mellifera (GLEAN3 set) (http://zulu.fmrp.usp.br/beelab/bioinfo blast). As ferramentas BLAST foram utilizadas, também, na verificação das seqüências obtidas por clonagem e 
sequenciamento (Item 3.9) Outras ferramentas computacionais também foram utilizadas, como ClustalW (http://align.genome.jp/), o programa para anotação de genes Artemis (Sanger, Release 7) e os softwares GeneRunner 3.05 e Primer3 para desenhar primers (Item 3.6).

\subsection{3' RACE do gene InR-2 (GB18331)}

A fim de esclarecer se a seqüência predita para o gene InR2 (GB18331) de aproximadamente $7000 \mathrm{pb}$ não estaria superestimada na sua extremidade 3', devido o tamanho do ortólogo em Drosophila (Ruan et al. 1995), realizamos uma reação 3'RACE utilizando o primer IR2-F (5' CGT TGG TCA TCA TGG AGT TG 3') que ancora dentro do domínio tirosina quinase e um primer oligo(dT)12-18 . O fragmento predito para esta reação seria um produto de aproximadamente 3500 pb.

Na reação de PCR utilizamos a enzima Platinum ${ }^{\circledR}$ Taq DNA Polymerase High Fidelity (Invitrogen). O mix de reação consistiu de 16,5 $\mu \mathrm{H} 2 \mathrm{O}$ deionizada bidestilada, 2,5 $\mu \mathrm{l}$ Tampão HiFi (Invitrogen), $1 \mu \mathrm{l}$ MgSO4 (50 mM), $1 \mu \mathrm{l}$ dNTP (10mM), $1,5 \mu \mathrm{l}$ de cada primer $(10 \rho \mathrm{mol} / \mu \mathrm{l}), 1 \mu \mathrm{l}$ de cDNA e $0,3 \mu \mathrm{l}$ de Taq Hi-Fi. O programa da amplificação consistiu dos seguintes passos: $95^{\circ} \mathrm{C}$ por 5 min; 50 ciclos - $95^{\circ} \mathrm{C}$ por $1 \mathrm{~min}, 52^{\circ} \mathrm{C}$ por $1 \mathrm{~min}, 72^{\circ} \mathrm{C}$ por $2 \mathrm{~min}$ - seguido por uma elongaçao final a $72^{\circ} \mathrm{C}$ por $10 \mathrm{~min}$. 


\section{Resultados}

\subsection{Identificação de genes candidatos da via IIS no genoma de Apis mellifera}

A fim de obter informações a respeito dos genes envolvidos na via do receptor de insulina, foi feita uma revisão bibliográfica sobre a via de insulina nos organismos metazoários. Os genes constituintes da via do receptor de insulina de $H$. sapiens, $M$. musculus e, principalmente, de Drosophila melanogaster serviram de base para uma busca no genoma de Apis mellifera e elaboração de uma tabela contendo os números de acesso ao banco de dados Oficial_Gene_Set (http://zulu.fmrp.usp.br/beelab/beelab/index html), onde se encontram as predições gênicas de Apis mellifera (Tabela 2).

Dois genes candidatos para receptores de insulina em Apis mellifera (GB15492 e GB18331) foram identificados pelas ferramentas blastp e blastn, anotados com o auxílio da ferramenta computacional Artemis (versão 7.0) e tiveram primers específicos desenhados para cada um deles (Item 3.6 - tabela 1). Posteriormente foram seqüenciados parcialmente e tiveram seus perfis de transcrição investigados em alguns estágios do ciclo de vida da abelha (Item 4.2).

Os genes codificadores para os receptores de insulina são denominados InR1 (GB15492) e InR2 (GB18331), que é a denominação atribuída por Dr. Miguel Corona, o anotador oficial do Consórcio de Genoma de Abelha designado para este grupo de genes.

Além dos dois genes codificadores para o receptor de insulina, foram identificados e analisados outros genes constituintes da via de sinalização IIS. Os genes Chico (GB11037), TSC-1(GB12676), TOR (GB11213) e S6K (GB19390) 
foram anotados com o auxílio da ferramenta computacional Artemis, analisados com ferramentas BLASTs, tiveram primers específicos desenhados para cada uma deles (Item 3.6 - tabela 1) e sua transcrição verificada por RT-PCR (Item 4.1.1). Além disso, os genes Chico e S6K foram parcialmente seqüenciados juntamente com os genes para os receptores de insulina.

Tabela 2: Genes integrantes à via de sinalização insulínica. Do lado esquerdo da tabela está representado o organismo do qual a sequência de busca foi obtida, o nome do gene e o número de acesso no GenBank; do lado direito da tabela está representado o provável ortólogo de cada gene em Apis mellifera com o seu número de acesso (GB) no banco de dados Official_Gene_Set, assim como o valor de similaridade (E-value) entre os genes de Apis mellifera e o seu correspondente no organismo da coluna 1.

\begin{tabular}{|c|c|c|c|c|c|}
\hline Organismo & Gene & $\begin{array}{c}\text { GenBank } \\
\text { number }\end{array}$ & Organismo & $\begin{array}{c}\text { Official gene } \\
\text { set }\end{array}$ & valor $\mathbf{E}$ \\
\hline D. melanogaster & $\operatorname{InR}$ & A56081 & A.mellifera & GB18331 & 0.0 \\
\hline D. melanogaster & $\operatorname{In} R$ & A56081 & A. mellifera & GB15492 & $e^{-109}$ \\
\hline D. melanogaster & $\mathrm{CHICO}$ & NM_164899 & A. mellifera & GB11037 & $5 e^{-49}$ \\
\hline D. melanogaster & FOXO isof. A & NM_142073.3 & A. mellifera & GB13873 & $8 e^{-34}$ \\
\hline D. melanogaster & FOXO isof. B & NP_996205.1 & A. mellifera & GB13873 & $2 e^{-61}$ \\
\hline D. melanogaster & FOXO isof. C & NP_996204.1 & A. mellifera & GB13873 & $8 e^{-62}$ \\
\hline D. melanogaster & Tsc1 & NM_058067.2 & A. mellifera & GB12676 & $e^{-77}$ \\
\hline D. melanogaster & S6K & NM_079217.2 & A. mellifera & GB19390 & $e^{-158}$ \\
\hline D. melanogaster & PTEN isof. B & NP_477423.1 & A. mellifera & GB14441 & $6 e^{-75}$ \\
\hline D. melanogaster & TOR & NM_080152.2 & A. mellifera & GB11213 & 0.0 \\
\hline D. melanogaster & TOR & NM_080152.2 & A. mellifera & GB18026 & $8^{\mathrm{e}-67}$ \\
\hline D. melanogaster & TOR & NM_080152.2 & A. mellifera & GB10887 & $7 e^{-52}$ \\
\hline D. melanogaster & TOR & NM_080152.2 & A. mellifera & GB16077 & $5 e^{-50}$ \\
\hline D. melanogaster & TOR & NM_080152.2 & A. mellifera & GB11176 & $5 e^{-32}$ \\
\hline H. sapiens & PTEN & NM_000314 & A. mellifera & GB14441 & $3^{e-91}$ \\
\hline Mus musculus & PDK1 & AA017164 & A. mellifera & GB15780 & $e^{-142}$ \\
\hline
\end{tabular}


4.1.1 Validação da transcrição de alguns genes integrantes da via IIS

Foram desenhados primers para os genes InR1, InR2, Chico, TSC1, TOR e S6K (Item 3.6) e a transcrição dos mesmos foi verificada por RT-PCR semiquantitativa (Figuras 9 e 10). Os primers utilizados para verificar a transcrição dos genes constituintes da via IIS foram: o par IR2-F e IR2-R para o gene InR2 (amplificando um fragmento de $\sim 600 \mathrm{pb}$ ); o par InR1-F e InR1-R para o gene InR1(amplificando um fragmento de $\sim 150 \mathrm{pb}$ ); o par TOR-F e TOR-R para o gene TOR (amplificando um fragmento de $\sim 370 \mathrm{pb}$ ), o par TSC1-F e TSC1-R para o gene TSC1 (amplificando um fragmento de $~ 700 \mathrm{pb}$ ), o par Chico-F e Chico-R para o gene CHICO (amplificando um fragmento de $\sim 640 \mathrm{pb}$ ) e o par de primers S6K-F e S6K-R para o gene S6K (amplificando um fragmento de 180pb) (Figura 9)

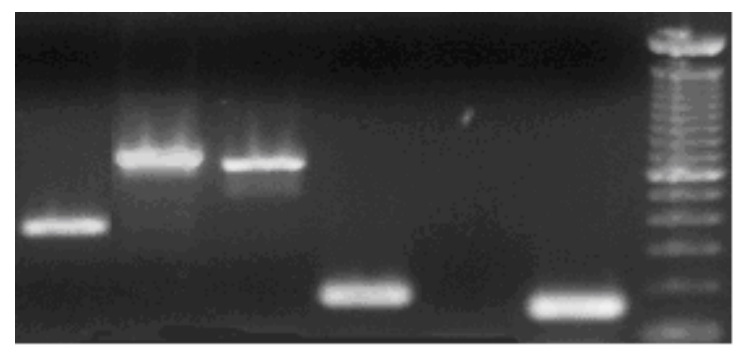

TOR TSCl Ohico $56 \mathrm{~K}$

Actina Mnooph

Figura 9: Gel de agarose 1,2\% corado com brometo de etídio. A RT-PCR com os primers específicos para os genes TOR ( 370pb), TSC1 ( 700 pb), CHICO ( 640pb), S6K ( 180pb) ocorreu à $60^{\circ} \mathrm{C}$, com 40 ciclos e o cDNA molde foi de rainha no quarto instar larval. Primer específico para actina $(\sim 150 \mathrm{pb})$ foi utilizado como controle positivo da amostra. 


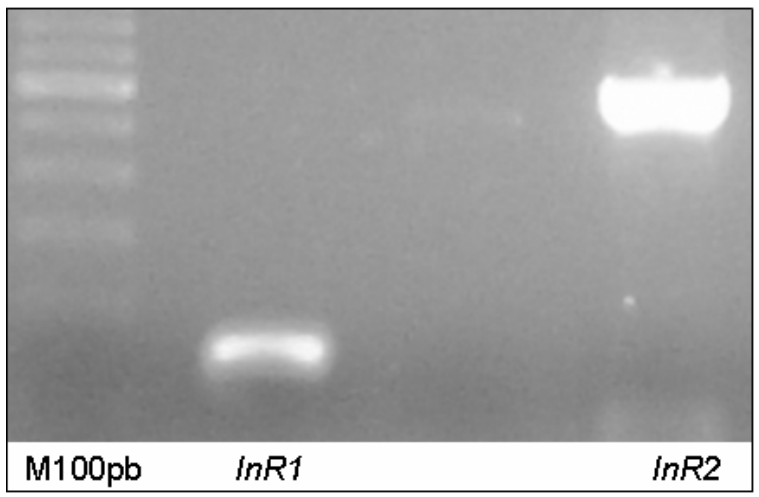

Figura 10: Gel de agarose 1,2\% corado com brometo de ethídio. A PCR com os primers específicos para os genes InR1 ( 150pb) e InR2 $(\sim 600 \mathrm{pb})$ ocorreu à $60^{\circ} \mathrm{C}$, com 40 ciclos e o cDNA molde foi de rainha no quarto instar larval.

\subsubsection{Anotação dos genes envolvidos na via IIS.}

\subsubsection{Gene codificador do receptor de insulina 1 (GB15492)}

A anotação na plataforma Artemis (versão 7.0) evidenciou que o gene predito como GB15492, de $4.320 \mathrm{nt}$, possui seis exons (Figura 11A). Para verificar os domínios conservados presentes em sua proteína utilizamos a ferramenta RPSBLAST (www.ncbi.nlm.nih.gov/Structure/cdd/wrpsb.cgi) e verificamos a presença dos domínios L (ligante), do domínio Furina, do domínio Fibronectina-tipo3 e do domínio Tirosina Quinase (Figura 11B), Os dois domínios L assim como o domínio Furina (região rica em cisteína) fazem parte da estrutura extracelular onde se liga o hormônio insulina ou os fatores de crescimento similar à insulina ao domínio L (Garrett, et al. 1998). O domínio Fibronectina-tipo3 é um tipo de domínio encontrado em vários tipos de proteínas, tais como receptor de fatores de crescimento e receptores tirosino-quinase. O domínio Tirosina-quinase é o domínio intracelular responsável pela transmissão de sinal para os mensageiros intracelulares como o inositol tri-fosfato (IP3) após ativação da enzima inositol-trifosfato quinase (PI3K). Foram desenhados primers específicos para esse gene 
(InR1-F e InR1-R), os quais amplificam um trecho de aproximadamente 151pb localizado no domínio tirosina quinase (Figuras 11A e 11B) que foi clonado e seqüenciado (Figura 11C).

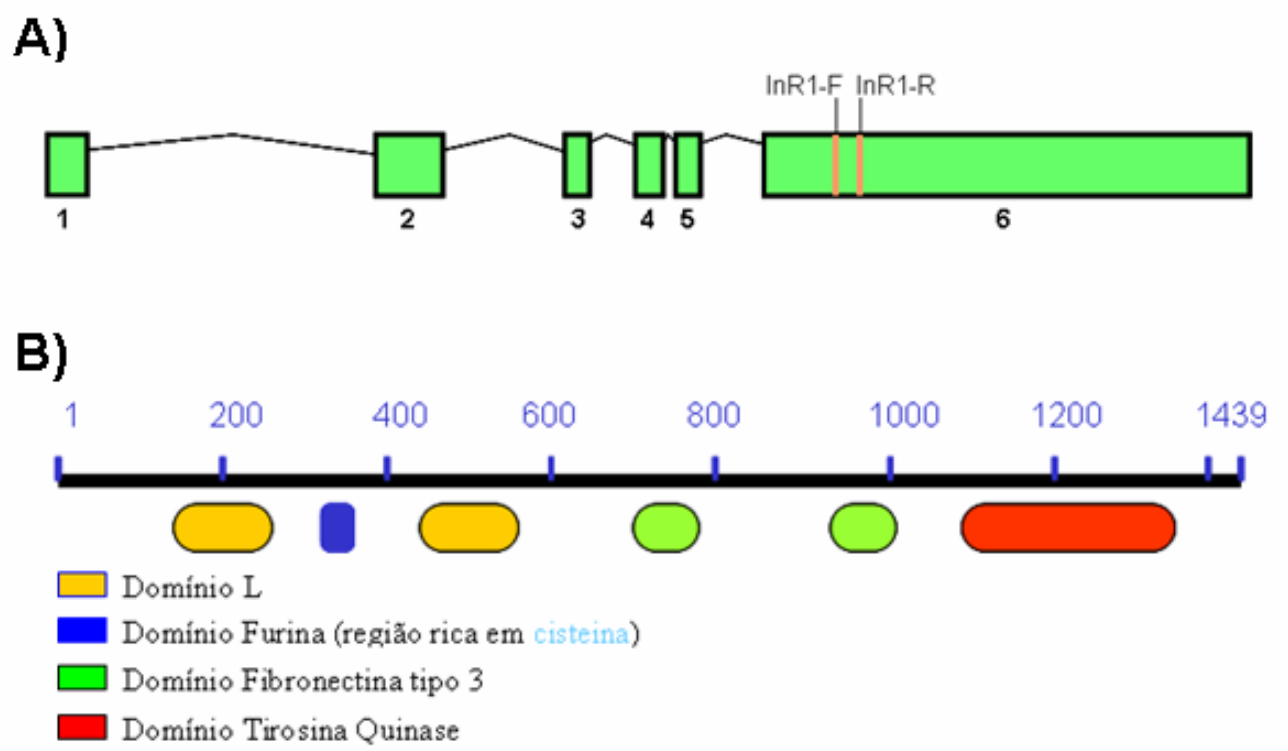

\section{C) \\ GGATCTGGTGTGGGACAGTTACAAGGCGCCCGAGGGGCAACAGTTGCTCAGCT ATCTGTTGAACTACATCGAGACGGAGAGCGAGAACATCACTTACGAGATGAACG CGTGCGGAGGGAACAACACGTGGCAGATACTCGACGTGGGGATA}

Figura 11: Gene InR1 de Apis mellifera. (A) O gene predito (GB15492) foi mapeado sobre o genoma (Amel versão 4.0) na plataforma Artemis (versão 7.0). Primers para validação da expressão por RT-PCR foram desenhados para um fragmento na região do domínio tirosina quinase, cobrindo parte do exon 6. (B) RPS-blast para detecção de domínios conservados. (C) Sequenciamento do fragmento de PCR de $151 \mathrm{pb}$ amplificado pelos primers InR1-F e InR1-R (marcados em negrito) correspondente ao domínio tirosina quinase.

A fim de verificar a similaridade entre o gene InR1 e o gene predito GB15492 foi feito análise BLASTN entre a seqüência do fragmento originado pelo par de primers InR1 e o banco de dados Official Gene Set, contendo os genes preditos do genoma de Apis mellifera. A similaridade obtida foi de 100\% (Figura 12). 


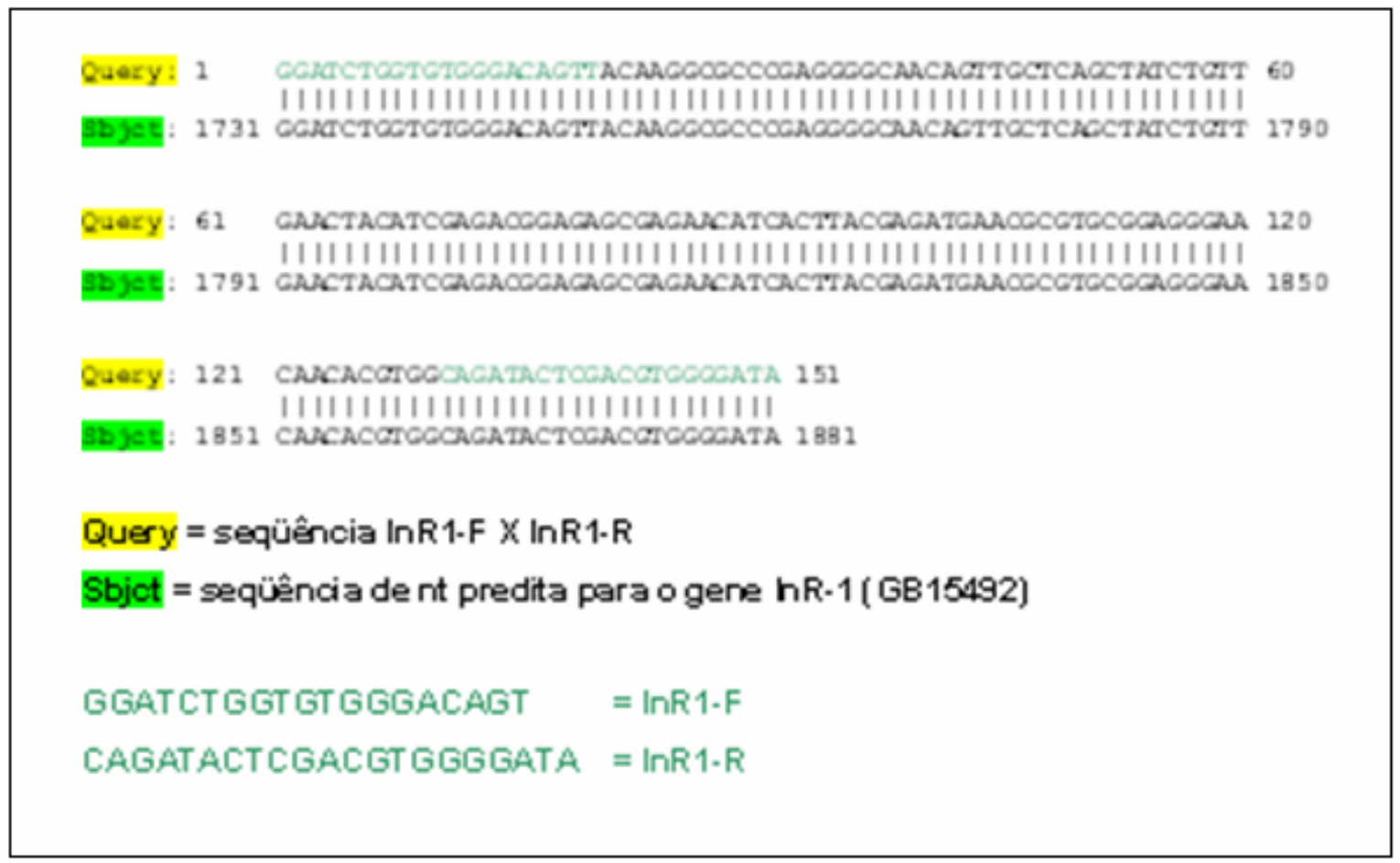

Figura 12: BLASTN do sequenciamento do produto de PCR obtido pelos primers InR1-F e InR1-R contra o banco de dados Official Gene Set (zulu.fmrp.usp.br/beelab/beelab). A identidade da seqüência foi de $100 \%$ entre o fragmento seqüenciado e o predito GB15492.

\subsubsection{Gene codificador do receptor de insulina 2 (GB18331)}

A anotação na plataforma Artemis (versão 7.0) evidenciou que o gene predito como GB18331, de 7.113 nt, possui treze exons (Figura 13A) Os domínios conservados foram verificados por RPSBLAST evidenciando que o gene predito GB18331 possui, além de todos os domínios descritos para o gene InR1 (Item 4.1.2.1) , o domínio PDZ que pode ser responsável por interações com outras moléculas (Figura 13B).

Foram desenhados três pares de primers para o gene InR2, dois no domínio furina e um no domínio tirosina quinase (Figura 13A). O par de primers IR3 (Figura 13A) amplifica um trecho de aproximadamente 550pb localizado no domínio furina. O par de primers InR2 amplifica um fragmento de aproximadamente 150pb localizado no domínio furina, esses primers foram desenhados por Wheeler e colaboradores (2006) (Figuras 13A e 13B) e foram utilizados para quantificação 
relativa (Item 4.2.2). O par de primers IR2 (Figura 13A) amplifica um fragmento de aproximadamente 625pb localizado no domínio tirosina (Figuras 13A e 13B). Os fragmentos obtidos com os pares de primers IR3 e IR2 foram clonados e sequenciados para validação experimental dos genes observados (Figura 13C). As seqüências dos fragmentos obtidas foram submetidas à análise BLASTN contra o banco de dados Official_Gene_Set . As similaridades observadas entre os fragmentos originados pelos pares de primers IR3 e IR2 foram, para ambos, de $98 \%$ com relação ao predito GB18331 (Figuras 14 e 15). 


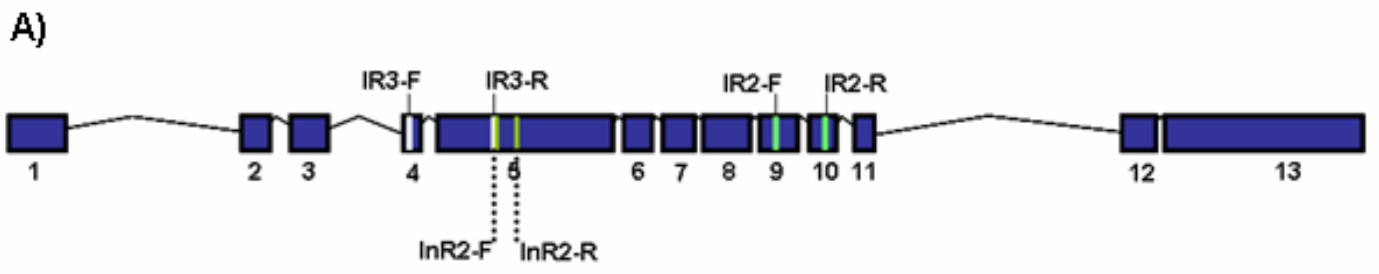

B)

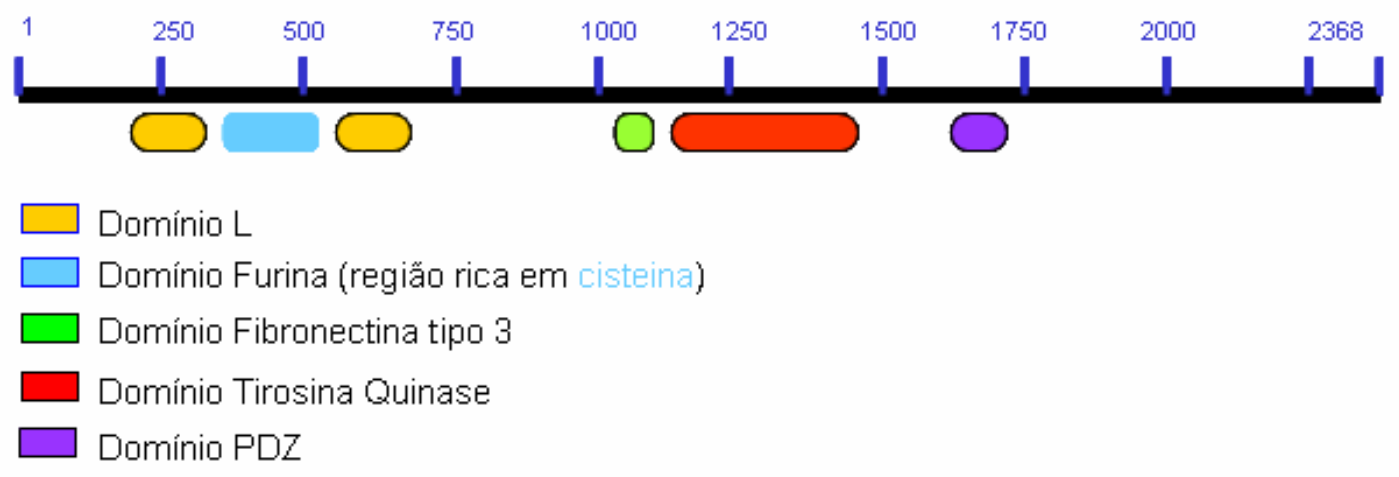

C) CGTTGGTCATCATGGAGTTGATGGTGAACGGGGAC TGAAGAGGTATC TGAGGAGCACACAG GCCGT GCGAGAACA TGTCGAACGCGCCCCCGAAAT TGGACAGGA TTC TCCAGA TGGCGATC GAGATCGCGGACGGGAT GCCGTACCT GTCCACGAAGAAGTTCGT GCACAGGGACTT GCCGG CCCGCAAT TGCATGGTGCCC GAGGATTTGNTT GTGAAGGTGGCC GAC TTT GGGATGACCAG GGACA TCT ACGAGAGGGATT ATT ACAGGAAGGGGAGCAAGGGTC TGT TCCCCGTTAGGTGG ATGGCGCCAGAGAGTCT GAAGGACGGGGT GTT CAGCAGCTATTCCGACGT GTGGAGCTACG GCGTCGTATTGTGGGAAATGGTCACC TTCGCGTCC CAGCCT TAT CAAGGT TTA TCGAACGA GCAGGTGCTGAGATACGTGATCGAGGGAGGTGTGA TGGAAACGGCCGGCAGAACTGTCCCG AGTTGCTGTACGAAGCT GAT GAAAGAGGGACC TGGGAGGCACAMGGGCAMCGA.AGGAGCCC GAACGTTCANT GGGACA TAAGCGGAGCANTGT TTGGNT GAAAACAAANCGAAC TTCGGAAA AGGTT TTCNAGGAAGGGTTAGCNTTTCTAATC ANANAC CCGGGAAAANNT CANTTAGGGGA ANTCGNGGGCCCGNCTGGCANGGTCNAACAAT AAT GGGGAAAMNCTCCAACGCGCTGGGA AAGCAMTAGCT TGGANAMAGTCT ABANGAGCCACCCTAAAATNRA

D) CCGAT GTTCTTCCMGCCCCGT ATCT GGATCT CGAGGCT GCCCTTT AT GTGCMT GCAGCCC CGAAGCTTCT GGGCCGAGGCGAT GCT GT CC ACGTTCGCGCCCGCGCACTCCTTCT GGC AL GAGCCCT CGCACTTCTT GCACGAGACCCTCCCGTT CGACTCGT CGT CC AT GT AGCCGGGC GGGCACT CC AT CACGCAGCT CCCGTT GAAAGGCTT GT ACGGGT AGTT CTT C ACGTT CTTC AAC ALCT CCTT C GGCTT CTCC AT TT GGAGGCATCTCGCCTCGTCT AT GCAACGGT GATTC AT GAACT CCAGGCTCCCGTTCGGGCACCGTTCCCT GCACTCCGASTCGCCCGTCACC ACG ICCTT GC ACACCGTACAGTCGCGATTCGTCGGCCCGCT GCACGT GCCC AGGCACGACGAG IGGCAAC AGTT CCCAGCCTCGT CGCACGCGTT GTT CT CGCACTTT CT GTCGCAGATTCGT TGGCAGT GTT GCT GGTT CCAACAGAGGT ATT CATCCT GCTT GGTCAGT CTTT GCGGAC AG IGCTTCTCGCACAC

Figura 13: Gene InR2 de Apis mellifera. (A) O gene predito (GB18331) foi mapeado sobre o genoma (Amel versão 4.0) na plataforma Artemis (versão 7.0). Primers para validação da expressão por RT-PCR foram desenhados para fragmento na região do domínio tirosino quinase (IR2) cobrindo parte dos exons 9 e 10 e para a região do domínio furina (IR3 e InR2) cobrindo parte dos exons 4 e 5. (B) RPS-blast para deteç̧ão de domínos conservados. (C) Sequenciamento do fragmento de PCR de 625 pb amplificado pelos primers IR2-F(marcado em verde) e IR2-R (não sequenciado) correspondente a uma região do domínio tirosina quinase. (D) Sequenciamento do fragmento de PCR de 550pb amplificado pelos primer IR3-F (em azul e seqüenciado parcialmente) e IR3-R (em azul seqüenciado completamente). 


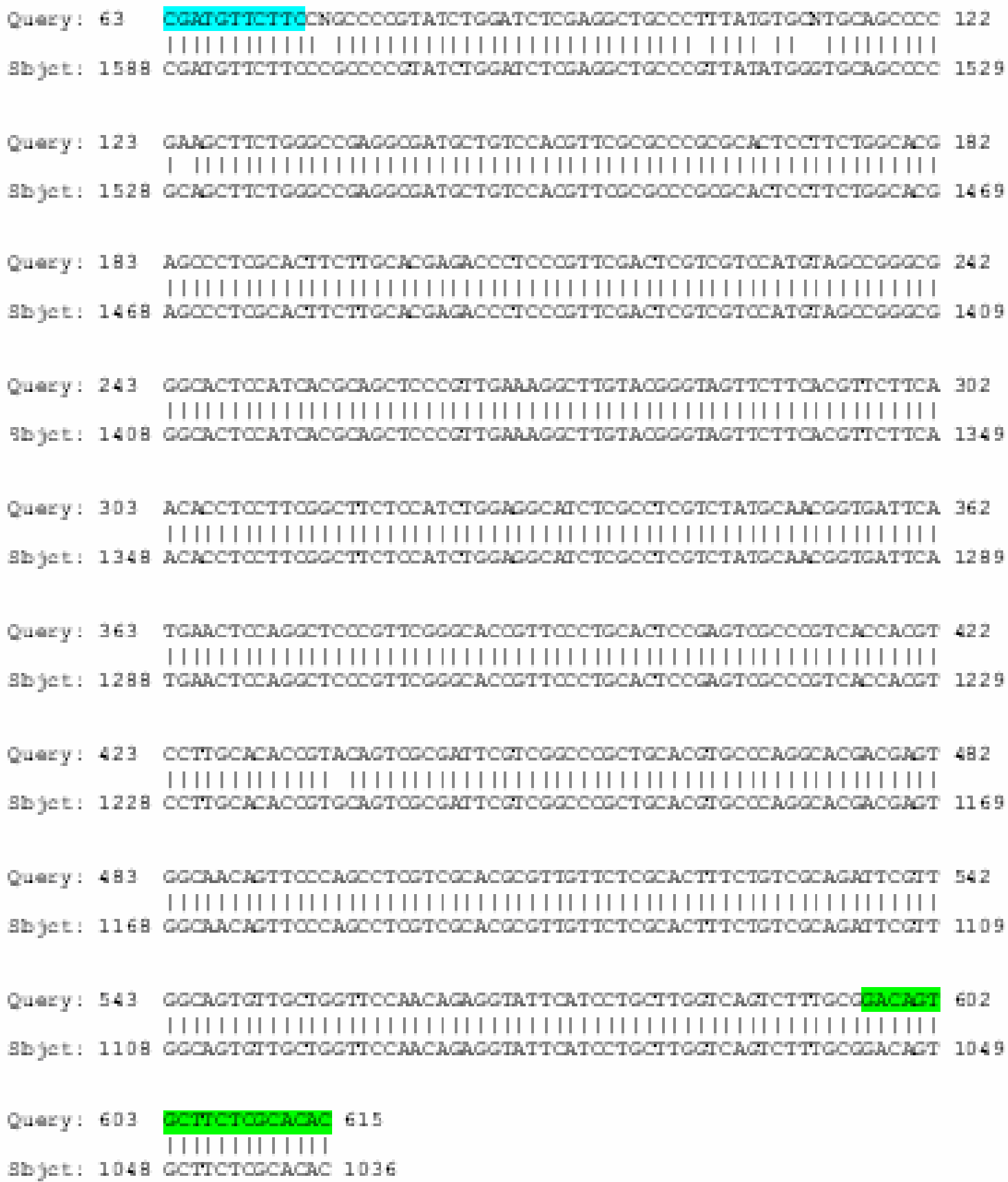

Figura 14: BLASTN do sequenciamento do produto de PCR obtido pelos primers IR3-F e IR3-R (query) contra o banco de dados Official Gene Set (zulu.fmrp.usp.br/beelab/beelab)(subject). A identidade da seqüência foi de $98 \%$ entre o fragmento seqüenciado e o predito GB18331. Em verde o primer IR3-F e em Azul a seqüencial parcial do primer IR3-R. 


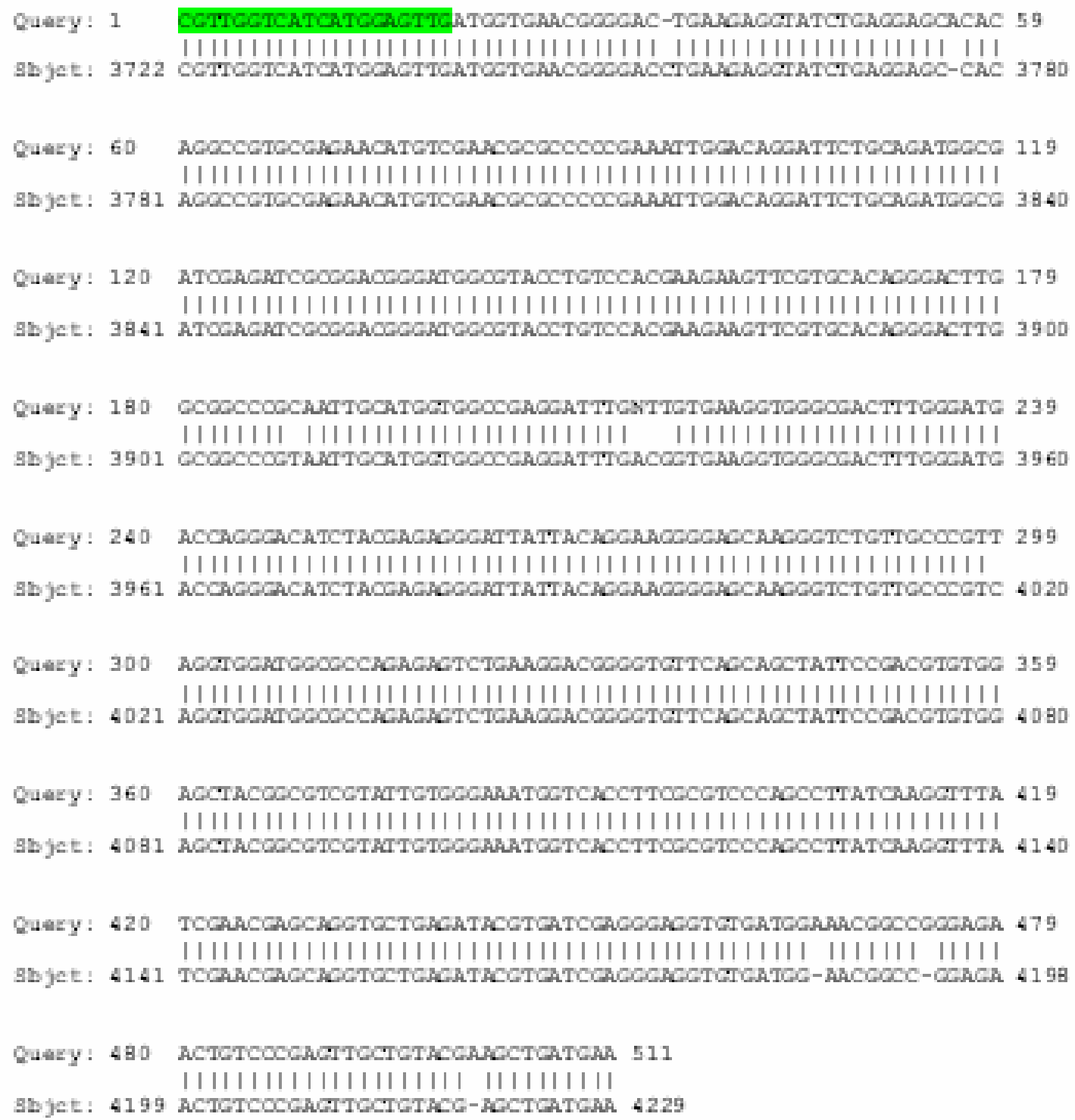

Figura 15: BLASTN do sequenciamento do produto de PCR obtido pelos primers IR2-F e IR2-R (query) contra $O$ banco de dados Official Gene Set (zulu.fmrp.usp.br/beelab/beelab)(subject). A identidade da seqüência foi de $98 \%$ entre o fragmento seqüenciado e o predito GB18331. O primer IR2-F aparece em verde e o primer IR2-R não foi seqüenciado.

4.1.2.3 Gene codificador do substrato do receptor de insulina (Chico)

A anotação na plataforma Artemis (versão 7.0) evidenciou que o suposto gene codificador para o substrato do receptor de insulina em Apis mellifera (Chico) possui 3681 nucleotídeos distribuidos em 10 exons (Figura 16A). A análise por RPSBLAST demonstrou a existência de dois domínios conservados: o domínio PH_IRS e o domínio IRS-PTB (Figura 16B). O domínio PH-IRS é encontrado apenas 
em eucariotos, e está freqüentemente envolvido em endereçar proteínas para a membrana plasmática em resposta ao estímulo por insulina. Após o domínio PH-IRS é encontrado o domínio IRS-PTB em moléculas do substrato de receptor de insulina e liga-se à fosfotirosinas que estão em motivos NPXpY no receptor de insulina/IGFs. Foram desenhados primers específicos para esse gene (Chico-F e Chico-R), os quais amplificam um trecho de aproximadamente 650pb localizado em uma região onde não há nenhum domínio conservado (Figuras 16A e 16B). O fragmento obtido com o par de primers Chico-F e Chico-R foi clonado e seqüenciado para validação experimental do gene candidato (Figura 16C).

A seqüência do fragmento obtido foi submetida à análise BLASTN contra o banco de dados Official_Gene_Set . A similaridade entre o fragmento originado pelo par de primers Chico-F e Chico-R foi de $87 \%$ com relação ao predito GB18331 (Figura 17). 


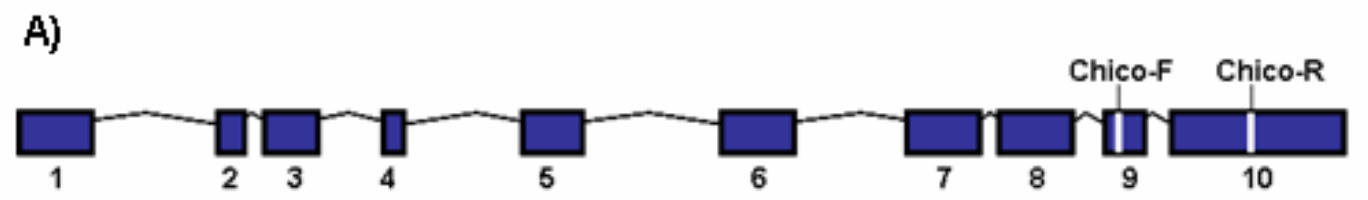

B)

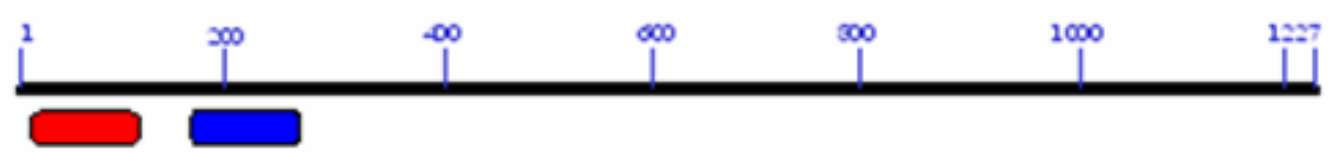

Domínio PH_IRS

Dominio IRS.PTE

C)
CATTCATGTAMC GTCTCTC CTTC CATACRTRAC CAC GRA TTAC GTA CTATTCAACCC

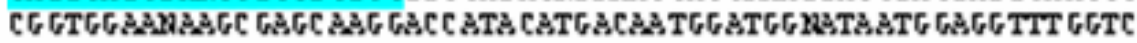 nC AATC CG, TGGT ABC CTAAGK ART TTCA TC GC CTA TGCAAGAA GAAAGR, TGC AATC GC AATG GRC CGCCAGGC AGC CAC GAGAACAG CABC GGT CGAT CTTC CAC GGGGRCAACCT GC C CAC TAT GTTGATATReA TTTC AAGC C GA GAAC AAGTTTA GAAC AAGATTC C CTAAGA TATGAA CAT GAGC AACT C GA GACAATC GTAAAC CAATG GCAA C CC TAA CC GCTACTC CT AAAGAGAAG TCAC GCTT C GC AnC AAGRTC GATC CAA GC GGRAA CTG CARC TATAAA

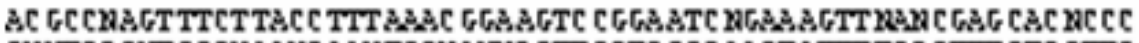

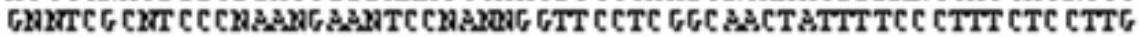

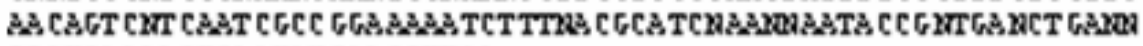 CC ATCAAAA CTGAATAT CAACCTTAA

Figura 16: Gene do substrato do receptor de insulina (AmChico) de Apis mellifera, ortólogo ao gene codificador do substrato do receptor de insulina de Drosophila (dChico) (A) O gene predito (GB11037) foi mapeado sobre o genoma (Amel versão 4.0) na plataforma Artemis (versão 7.0). Primers para validação da expressão por RT-PCR foram desenhados para fragmento na região 3' cobrindo parte dos exons 9 e 10 (B) RPS-blast para detecção de domínios conservados. (C) Sequenciamento do fragmento de PCR de aproximadamente $620 \mathrm{pb}$ amplificado pelos primers Chico-F(marcado em azul). O Chico-R não foi seqüenciado. 
QUAEY: 1 CATTCATCTANCGTOCTCTOCTTCCACACNTNACCAOCNALTAOGTACTATTCAROCC GD gbjet: 2532 cal||||||| |||||||||||||||||| | |||| || |||||| ||| |||||| || Sbjet: 2532 CATTCATCTATCGTOCTCTOCTTCCACACACAACC-CGTAATTAC-TAC-ATTCAAOCC 25日B

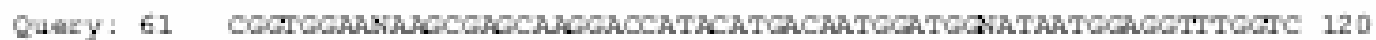
||||||| |||| || ||||||||||||||| ||||||||| |||||||||| ||||||

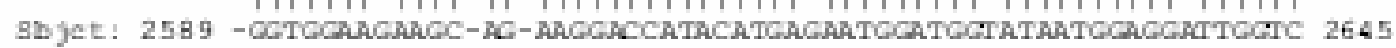
QueYY: 121 NCARTCOGGTCGTANCCCTAACNTANTTTCACCOCCTATGCARCARARACNGTOCARC 1BD

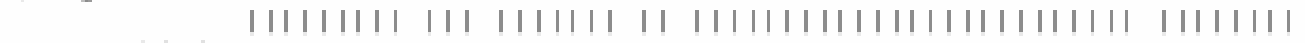

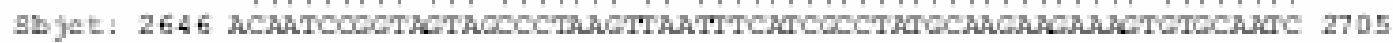

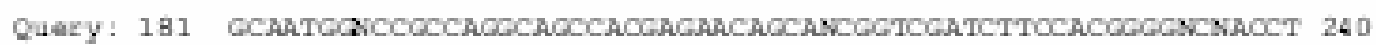
| ||||| |||||||| |||||||||||||||| ||||||||||||||||| | | ||||

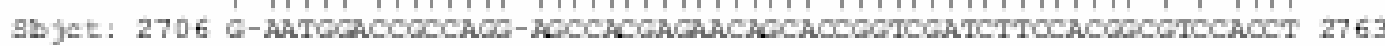

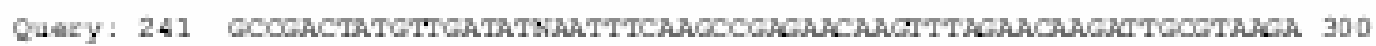
||||||||||||||||| |||||||||||||||||||||||||||||||||| | ||| |

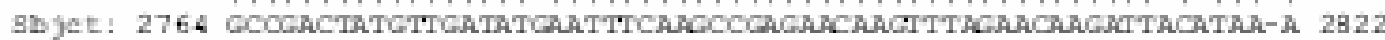

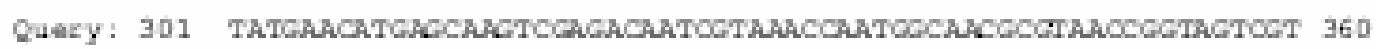
||||||||||||||| |||| ||||||||||||||||||||||||| |||||||||||||

Sbjet: 2823 TATCAACATGACCAA-TCGARACAATOGTAAACCAATGOCAROGCG-AROCGGTAGTOGT 28 BD

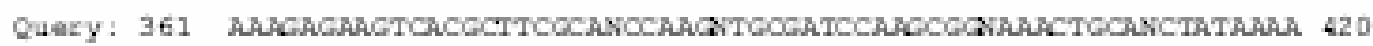
||||||||||||| |||||| |||| |||||||||||||| |||| | ||||||||

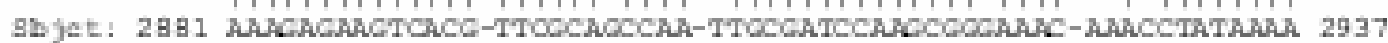

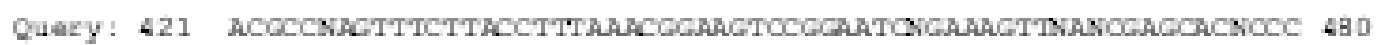

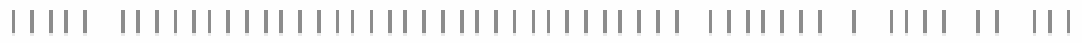

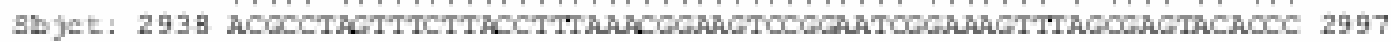

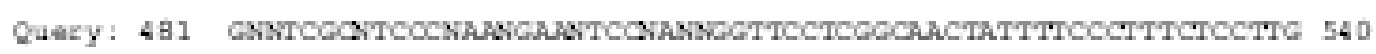
| || | |||| | || ||| | ||||||||||| |||||||||||||||||||||

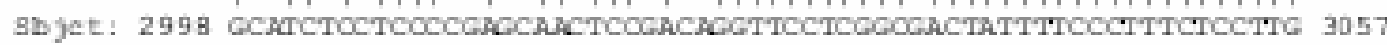

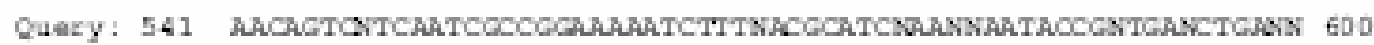
||||||| ||||||||| || ||||| || ||||||| || ||||||| ||| ||||

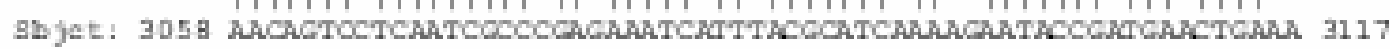

QuEYy: 601 CCACCARACTCARTATGARCTTAR 626

|||||| ||||||||||||||||||

Sbjet: 311 B CCACCACAACTCARTATCARCCTTAR 3143

САTTCAT GTATC GT CCTCTGC $=$ CHI CO-F

Figura 17: BLASTN do sequenciamento do produto de PCR obtido pelos primers Chico$F$ e Chico-R (query) contra o banco de dados Official Gene Set (zulu.fmrp.usp.br/beelab/beelab)(subject). A identidade da seqüência foi de $87 \%$ entre o fragmento seqüenciado e o predito GB11037. 


\subsubsection{Gene codificador da quinase ribossomal S6K}

A anotação na plataforma Artemis (versão 7.0) evidenciou que o suposto gene codificador para a proteína da quinase ribossomal S6K de Apis mellifera possui 1400 nucleotídeos e 12 exons (Figura 18A). A análise de domínios conservados por RPSBLAST demonstrou que a proteína predita de Apis mellifera possui o domínio S_TKc, que é o domínio catalítico de proteína serina/treonina quinase e o domínio S_Tk_X, que é uma extensão do domínio S_Tk (Figura 18B). Foram desenhados primers específicos, S6k-F e S6K-R, para validação por RT-PCR de sua transcrição. O fragmento amplificado por esse par de primers foi clonado e seqüenciado (Figura 18-C). A similaridade entre o fragmento seqüenciado e o gene predito (GB11037) foi verificada via BLASTN contra o genoma de Apis mellifera e a similaridade obtida foi de $92 \%$ (Figura 19). 
A)

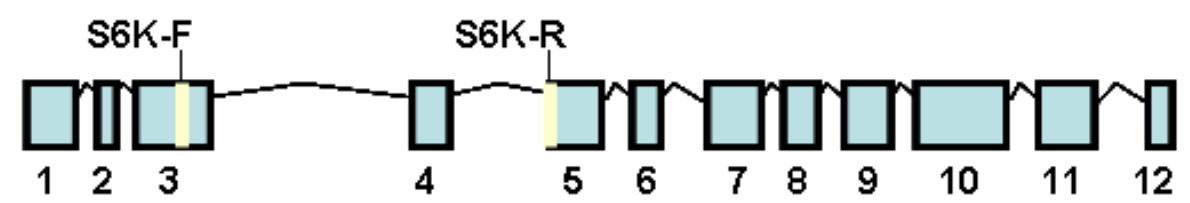

B)

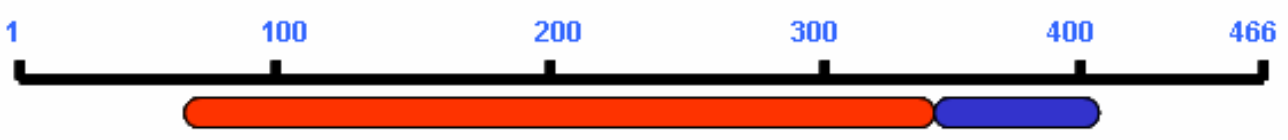

Domínio S_TKC, Serine/Threonine protein kinases, catalytic domain

Domínio S_TK_X, Extension to Ser/Thr-type protein kinases

C)

\begin{abstract}
TATGGCAAGGT TTT TCAAGT GCGMAA AAT UTM GGGMTC CACCM CMTCAC AAT CTT TGC GA TG AAG GTCTT ACGT AAGGCT TCA ATT AT A AGG AAC CAAAAAGAT ACT GCACAT ACT AAGGC TGAAAGAAMT ATTT TAGAAGCTGTAAAGC ATC CTT TCATCGTAGACC
\end{abstract}

Figura 18: Gene da proteína quinase ribossomal S6Kde Apis mellifera, (A) O gene predito (GB19390) foi mapeado sobre o genoma (Amel versão 4.0) na plataforma Artemis (versão 7.0). Primers para validação da expressão por RT-PCR foram desenhados, cobrindo parte dos exons 3 e 5 e por completo o exon 4. B) RPS-blast para detecção de domínios conservados. (C) Sequenciamento do fragmento de PCR de aproximadamente 180pb amplificado pelos primers S6K-F e S6K-R (marcados em verde).

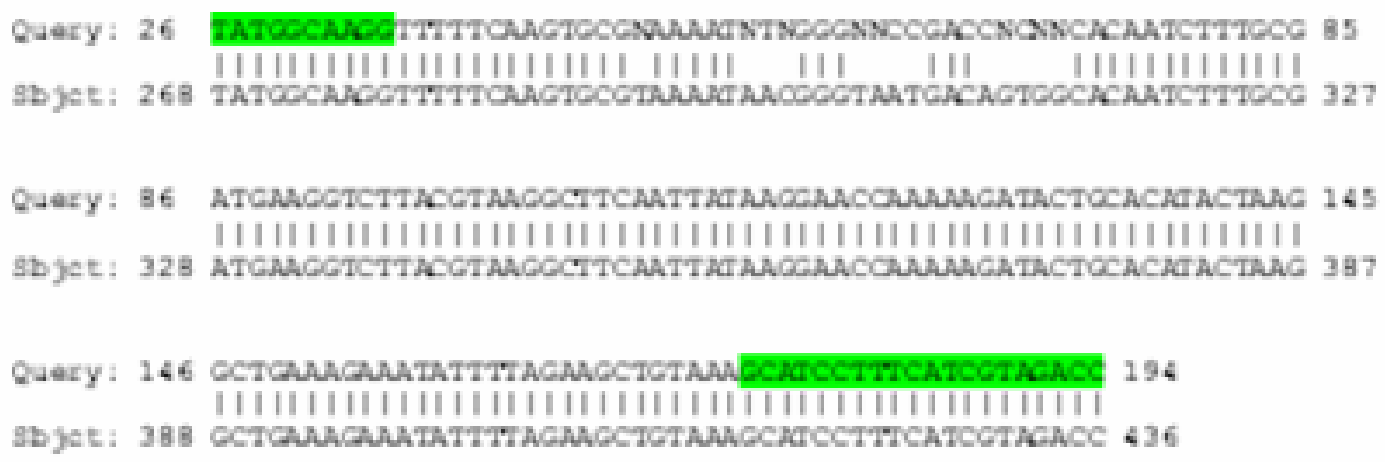

Figura 19: BLASTN do sequenciamento do produto de PCR obtido pelos primers S6K-F e S6K-R (query) contra $O$ banco de dados Official Gene Set (zulu.fmrp.usp.br/beelab/beelab)(subject). A identidade da seqüência foi de $92 \%$ entre o fragmento seqüenciado e o predito GB19390. 
4.1.2.5 Gene codificador do supressor de tumor TSC1

O gene TSC1 codifica uma proteína envolvida na via de sinalização da insulina e na via de sinalização TOR (Bateman \& Neill 2004) modulando negativamente o controle dessas vias e, portanto sendo um importante componente da via IIS/TOR. Nesse trabalho nós o identificamos (Item 4.1) no genoma de Apis mellifera, o anotamos na plataforma Artemis (Versão 7.0) (Figura 20A) e, com a ferramenta computacional RPSBLAST, verificamos os domínios conservados contidos na proteína predita (GB12676) (Figura 20B). A anotação e análise por RPSBLAST evidenciaram que o transcrito do gene TSC1 possui 14 éxons (Figura 20A) e é traduzido em uma proteína com o domínio Harmantina e o domínio ABC_SHC4_euk (Figura20B). Embora não tenha sido seqüenciado, a presença de seu transcrito foi validada através de RT-PCR com a utilização de primers específicos para esse gene em Apis mellifera, Tsc1-F e Tsc1-R (Item 4.1.1 Figura 9). 
A)

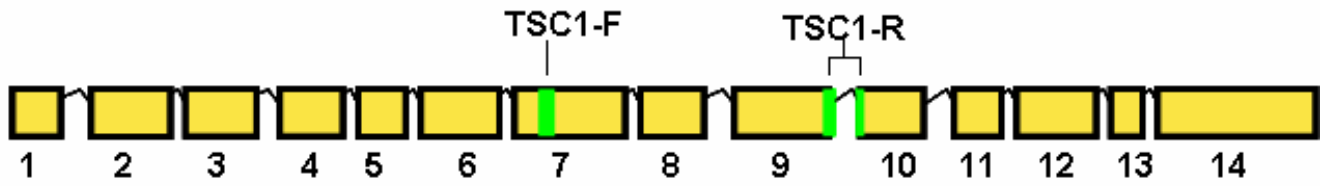

B)

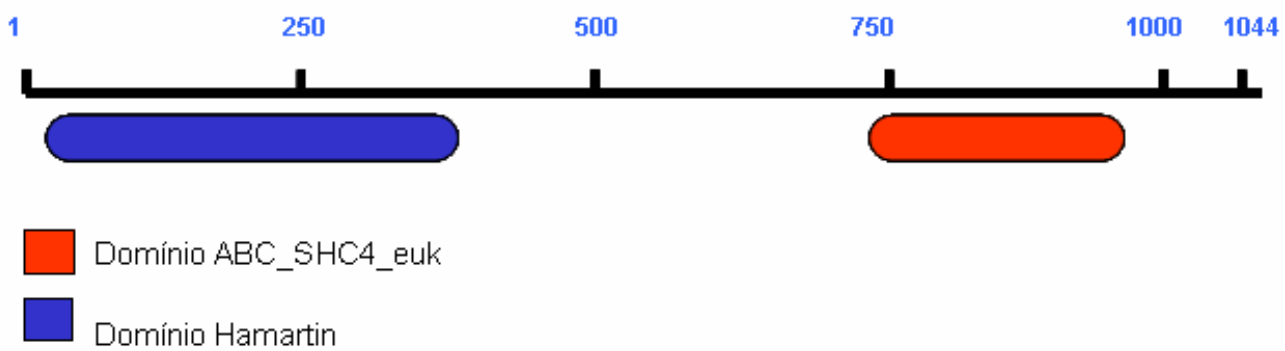

Figura 20: Gene da proteína supressora de tumor TSC1 de Apis mellifera, (A) O gene predito (GB12676) foi mapeado sobre o genoma (Amel versão 4.0) na plataforma Artemis (versão 7.0). Primers para validação da expressão por RTPCR foram desenhados, cobrindo parte dos éxons 7 e 10 e por completo os éxon 8 e 9. B) RPS-blast.para detecção de domínios conservados.

\subsubsection{Gene codificador de uma proteína alvo de rapamicina (TOR)}

Para o gene TOR de Drosophila melanogaster (GenBank accession number NM_080152) foi verificado em Apis mellifera a existência de seis preditos que são possíveis genes pertencente a família TOR (Item 4.1-Tabela 3). Dos seis preditos, escolhemos um para análise devido a maior similaridade com seu ortólogo em D.melanogaster (Item 4.1-Tabela3). O suposto gene para TOR em Apis (GB11213) teve sua seqüência anotada e analisada por ferramenta BLAST. A anotação do predito na plataforma Artemis (Versão 7.0) e a verificação dos domínios conservados por RPSBLAST evidenciaram que 0 transcrito para 0 alvo de rapamacina de Apis mellifera com o número de acesso, ao banco de dados Official_Gene_Set, GB11213 apresenta seis éxons (Figura 21A). A proteína traduzida possui três domínios conservados característicos das proteínas alvos de 
rapamicina (Figura 21B): um domínio $\mathrm{PI3K}$ relacionado $(\mathrm{PI} K \mathrm{Kc})$ e dois domínios adicionais FAT, um em posição C-terminal e o outro $\mathrm{N}$-terminal em relação ao domínio PI3K (Figura 21). Embora o transcrito não tenha sido seqüenciado para o suposto alvo de rapamicina (GB11213), sua transcrição foi validada por RT-PCR com primers específicos desenhados para esse gene (TOR-F e TOR-R) (Item 4.1.1Figura 9).

A)

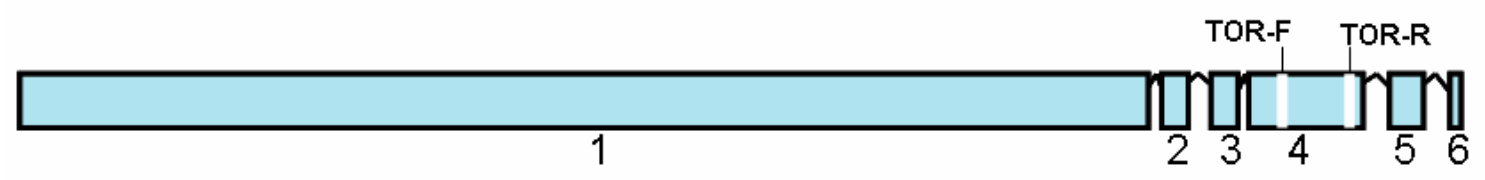

B)

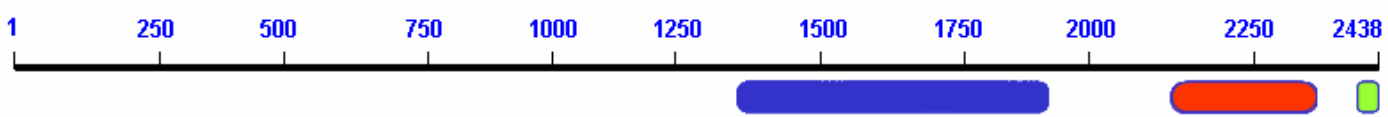

$\square$ Domínio PI3Kc_related

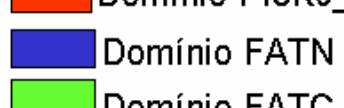

Figura 21: Gene codificador da proteína alvo de rapamicina (TOR) de Apis mellifera. $O$ gene predito (GB11213) foi mapeado sobre o genoma (Amel versão 4.0) na plataforma Artemis (versão 7.0). Primers para validação da expressão por RT-PCR foram desenhados, cobrindo parte do éxon 4. B) RPS-blast para detecção de domínios conservados. 


\subsection{Perfil de transcrição dos genes envolvidos na via IIS em Apis mellifera}

Entre os genes envolvidos na via IIS, apenas os genes codificadores para os receptores de insulina tiveram seus níveis de transcrição verificados, uma vez que eles são os responsáveis pela transdução do sinal do ambiente externo da célula, hemolinfa, para o ambiente interno da célula.

O gene para o receptor de insulina InR-2 (GB18331) é estudado em Apis mellifera, e por isso foi o único a ter seu perfil de transcrição pré-traçado por RTPCR semiquantitativa ao longo da fase de desenvolvimento pré-embrionário e posteriormente refinado por qRT-PCR Já o gene InR1 (GB15492), o qual teve sua transcrição validada primeiramente por nós, teve seu perfil ao longo dos estágios de desenvolvimento larval estabelecido diretamente por RT-PCR quantitativa.

Verificamos também os níveis de transcrição dos receptores de insulina de Apis mellifera nos ovários de operárias e rainhas, em amostras de operárias tratadas com $\mathrm{HJ}$ e em amostras de operárias adultas mantidas sob diferentes tipos de alimentação.

\subsubsection{RT-PCR semiquantitativa do gene codificador de InR2 (GB18331)}

Para verificar a presença do transcrito $\operatorname{lnR} 2$ em todos os estágios do desenvolvimento pós embrionário de operárias e rainhas de Apis mellifera foi feita uma RT-PCR semiquantitativa com os primers específicos IR2-F e IR2-R.

Tanto em rainhas quanto em operárias os transcritos para o gene InR2 foram detectados em todos os estágios do desenvolvimento pós-embrionário (Figuras 22A e 22B). 


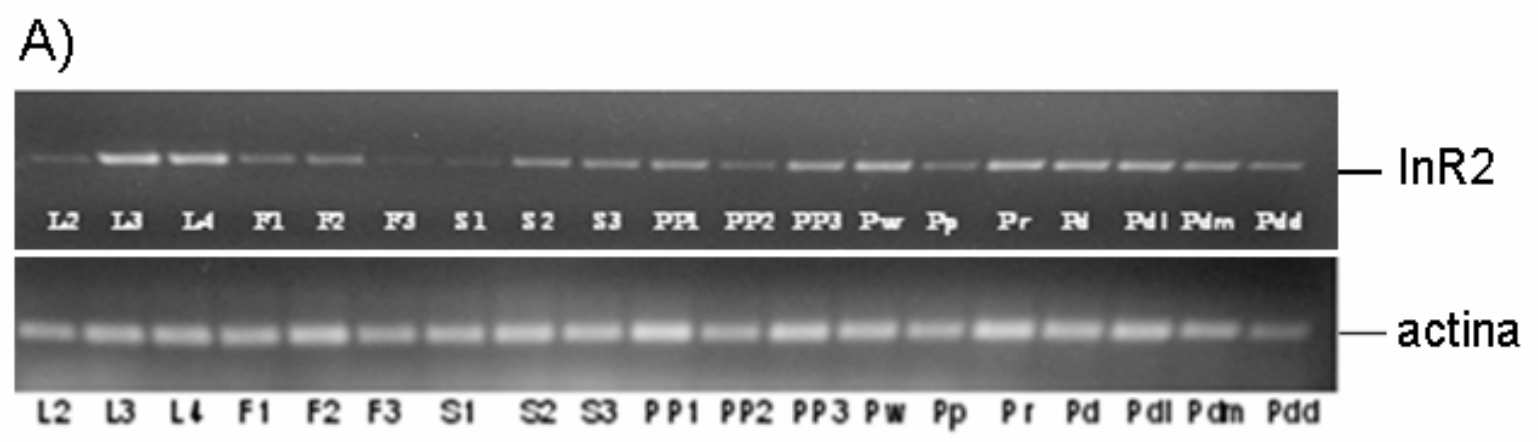

B)

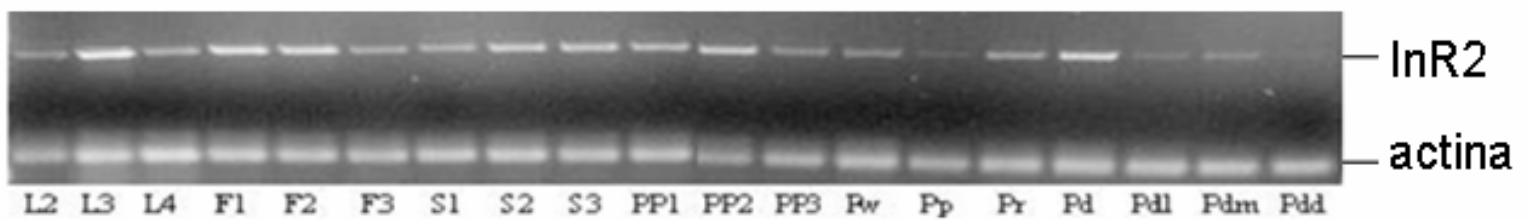

Figura22: Gel de agarose $1,2 \%$ das amostras de RT-PCR de operárias $(A)$ e rainhas $(B)$ obtidas com os primers específicos para o gene InR2 (IR2-F e IR2-R) em 35 ciclos. O fragmento amplificado, InR2, corresponde ao transcrito do gene $\ln R-2$ e possui aproximadamente $625 \mathrm{pb}$. As amostras foram normalizadas para actina.

\subsubsection{RT-PCR quantitativa (qRT-PCR) dos genes InR1 (GB15492) e InR2} (GB18331).

A análise por RT-PCR quantitativa foi utilizada para verificar e quantificar os níveis de transcrição dos receptores de insulina de Apis mellifera em larvas de operárias e rainhas, nos ovários de operárias e rainhas, em amostras de operárias tratadas com $\mathrm{HJ}$ e em amostras de operárias adultas mantidas sob diferentes tipos de alimentação.

Os primers utilizados nas reações de qRT-PCR (Real time) tiveram suas eficiências verificadas de acordo com a metodologia de Pfaffl (2001). O par de primers $\operatorname{lnR}$-1 apresentou os valores do coeficiente de regressão $(R)$ de 0,998 , de slope de $-3,317$ e E=2,0. Para o par de primers $\ln R 2$ apresentou os valores do coeficiente de regressão $(R)$ de 0,998, de slope de -3,244 e E=2,0. 
4.2.2.1 Transcrição dos genes codificadores dos receptores de insulina InR1 e InR2 em larvas de rainhas e operárias

As análises por RT-PCR quantitativa, realizadas com cDNA de larvas de operárias e rainhas de Apis mellifera, iniciaram com o período no qual ocorre a troca de alimentação (L3 para L4). Para as comparações entre os níveis de transcrição dos genes codificadores para InR1 e InR2 em ambas as castas, de operárias e rainhas, todos os valores $\Delta \mathrm{CT}$ obtidos foram calibrados pelo valor $\Delta \mathrm{CT}$ do gene InR-1 da fase L3. Neste período de troca de alimento, notamos diferenças consideráveis entre as castas nos níveis de transcrição do receptor $\ln R-1$ (GB15492), mas, níveis similares para InR-2 (GB18331) (Figuras 23 e 24). Em rainhas na fase $L 3$, o nível de transcrição do gene InR1 era cerca de cinco a dez vezes maiores do que nos estágios que o sucedem (Figura23), enquanto o nível de transcrição de InR-2 (GB18331) inicia-se em um nível bem mais baixo que InR-1 e, com o fim da fase de alimentação (L5F3 para L5S1), cai para níveis basais (Figura 23). Em operárias, os níveis de ambos os genes, InR-1 e InR-2 ficaram em nível basal em L3, seguido de um aumento quase paralelo para os dois genes até L5F1 (Figura 24). Diferentemente das rainhas, em operárias, ambos os genes permanecem com níveis de transcrições elevados, mesmo após o término da fase de alimentação (Figura 24). 


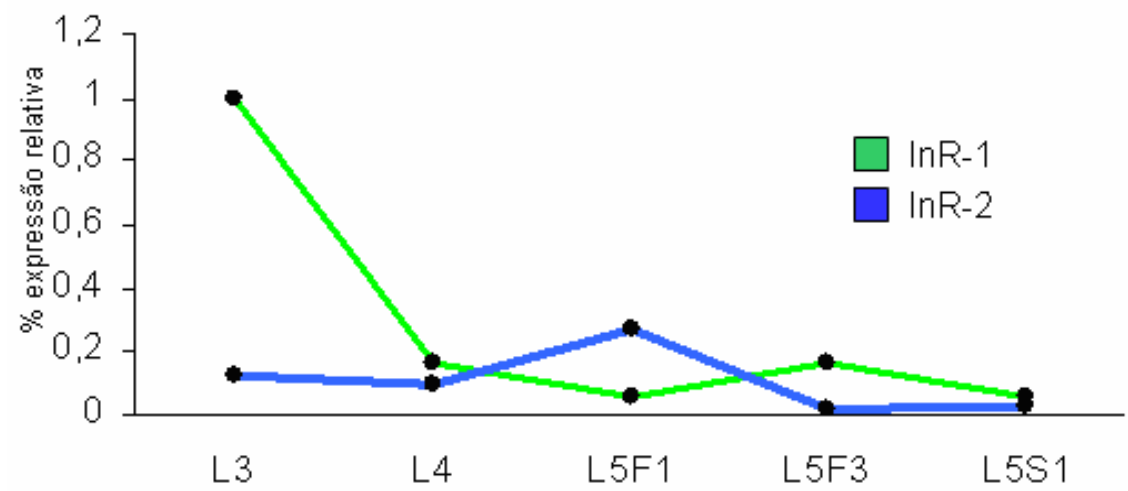

Figura 23: Perfil de transcrição dos genes codificadores dos receptores de insulina (InR-1 e InR-2) em rainhas de Apis mellifera durante o período de desenvolvimento onde ocorre a troca de alimentação entre operárias e rainhas ( $3^{\circ}$ instar) até o inicio da fase de tecelagem do casulo (L5F1) Os valores da expressão relativa foram calculados utilizando a metodologia Pfaffl (2001) e as amostras foram calibradas para InR1 de rainha na fase L3. (ratio $=1)$.

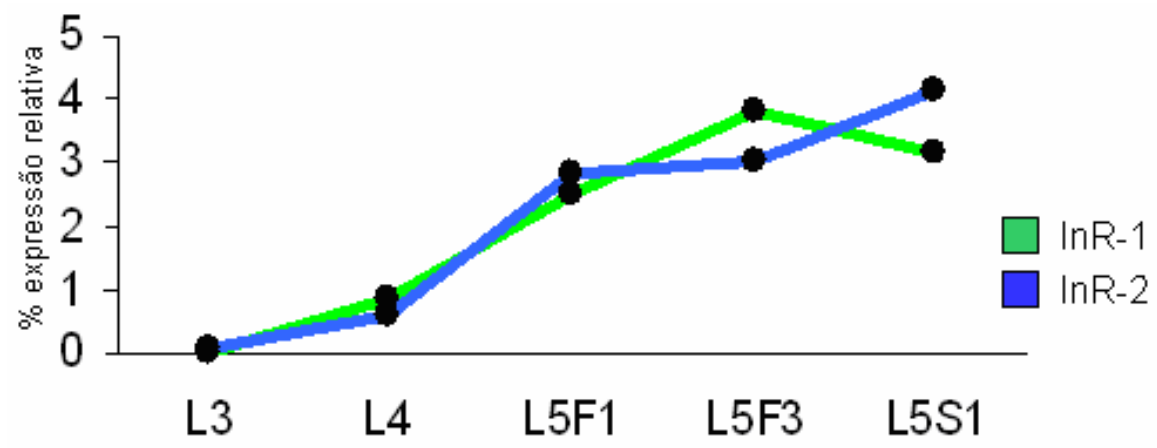

Figura 24: Perfil de transcrição dos genes codificadores dos receptores de insulina (InR1 e InR2) em operárias de Apis mellifera durante o período de desenvolvimento onde ocorre a troca de alimentação entre operárias e rainhas ( $3^{\circ}$ instar) até o inicio da fase de tecelagem do casulo (L5F1). Os valores da expressão relativa foram calculados utilizando a metodologia Pfaffl (2001) e as amostras foram calibradas para InR1 de Rainha na fase L3. (ratio =1) afim de compará-las em uma mesma escala. 
4.2.2.2 Transcrição dos genes codificadores dos receptores de insulina InR1 e InR2 nos ovários de rainhas e operárias

Os perfis transcricionais para estes genes foram obtidos através do RNA extraído do corpo total das larvas e posteriormente foram realizadas análises tecidoespecíficas da sua transcrição. Escolhemos para tais anos ovários, já que estes apresentam as maiores diferenças entre as castas.

Os perfis de transcrição dos genes InR1 e InR2 obtidos por qRT-PCR nos ovários de operária e rainhas nas fases larvais L4, L5F3; L5S1, L5S3 e PP1 (figuras 25 e 26) demonstram diferenças tanto no perfil temporal quanto nos níveis de transcrição. Em ambas as castas, a maior modulação nos níveis de transcrição foi observado para o receptor InR2. No ovário das rainhas notou-se um aumento agudo porém transiente na fase L5F3, que antecede imediatamente o início da fase de operculação, e um segundo aumento, em menor nível, na fase final da tecelagem do casulo (L5S3). Em seguida, no início da fase prépupal (PP1), observou-se um aumento na transcrição do gene $\ln R 1$ que, até este ponto, mostrou pouca modulação. Em ovários de operárias, a modulação mais marcante foi notada entre o quarto e quinto instar larval onde houve uma diminuição drástica nos níveis de transcrição de InR2. É importante ressaltar que para realizar estas comparações entre as castas, fases de desenvolvimento e os dois receptores, todos os valores $\Delta \mathrm{CT}$ obtidos foram calibrados pelo valor $\Delta \mathrm{CT}$ do gene $\operatorname{lnR}-2$ da fase $L 4$. 


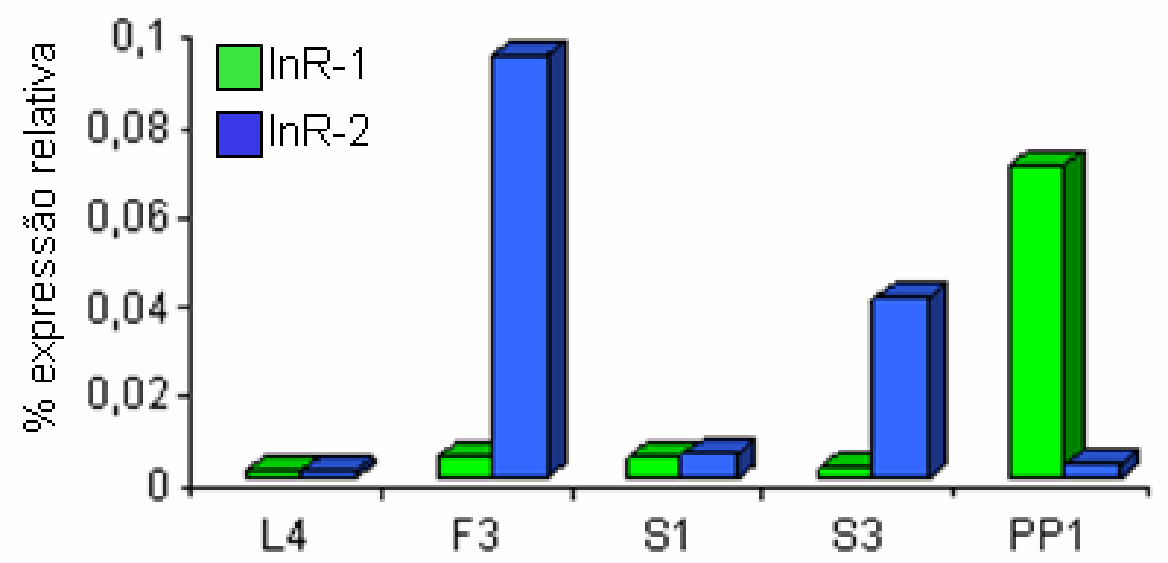

Figura 25: Perfil de transcrição dos genes codificadores dos receptores de insulina (InR-1 e InR-2) em ovário de rainhas de Apis mellifera. Foram selecionadas fases nas quais os ovários se encontram em diferentes estágios do desenvolvimento.Os valores da expressão relativa foram calculados utilizando a metodologia Pfaffl (2001) e as amostras foram calibradas para InR2, no estágio L4 de operária, afim de manter os dados em uma mesma escala.

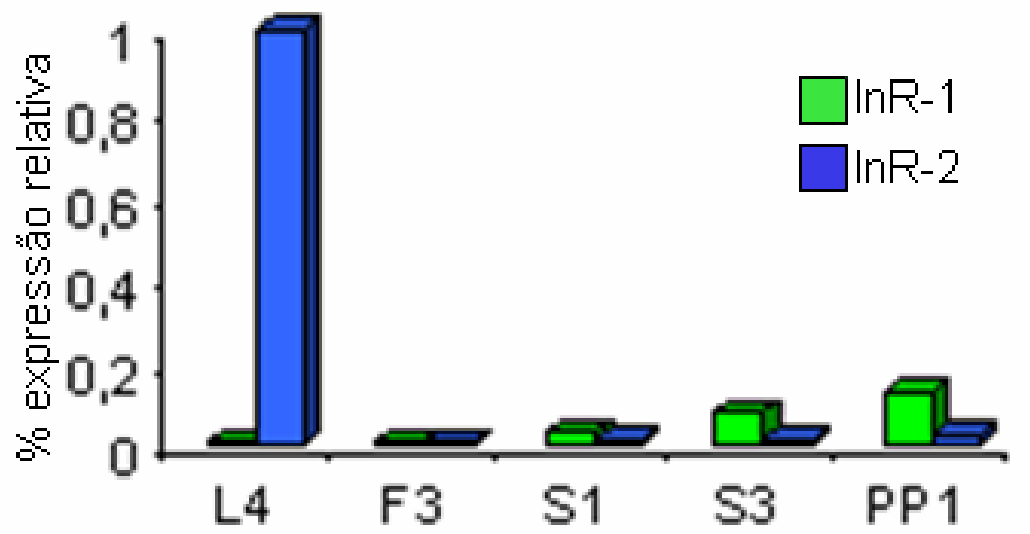

Figura 26: Perfil de transcrição dos genes codificadores dos receptores de insulina (InR-1 e InR-2) em ovário de operárias de Apis mellifera. Foram selecionadas fases nas quais os ovários se encontram em diferentes estágios do desenvolvimento.Os valores da expressão relativa foram calculados utilizando a metodologia Pfaffl (2001) e as amostras foram calibradas para InR2 de operária L4 $($ ratio $=1)$. 
4.2.2.3 Efeito de tratamento com pyriproxifen sobre a transcrição dos genes InR1 e InR2 em larvas de operárias

Para investigar a possível interação entre a via de sinalização IIS e o hormônio juvenil tratamos as larvas de operárias no quarto instar larval com pyriproxifen, um análogo de HJ. Como controles, utilizamos amostras tratadas com o respectivo solvente (hexano) e sem tratamento algum. As larvas foram coletadas 6 e 24 horas após tratamento para extração de RNA e síntese de cDNA. A transcrição de InR1 e InR2 foi analisada por qRT-PCR.

No grupo com 6 horas após tratamento houve um aumento na transcrição de ambos os genes nas amostras tratadas com $\mathrm{HJ}$, assim como nas amostras tratadas com o hexano. No entanto, quando os níveis de transcrição foram analisados nas amostras coletadas 24 horas após o tratamento, observamos que o efeito de tratamento com solvente tinha desaparecido e que somente as larvas tratadas com pyriproxifen mostraram níveis elevados de transcrição para os genes $\ln R 1$ e $\ln R 2$ com relação aos grupos controles (Figuras 27 e 28). Neste experimento utilizamos como calibradores os valores do $\triangle \mathrm{CT}$ de cada gene (InR1 e InR2) de larvas não tratadas e coletadas 2 horas após o tratamento com HJ.

Este resultado mostra um claro efeito de $\mathrm{HJ}$ sobre a transcrição dos dois genes, no entanto o resultado surpreende quando nos comparamos os valores obtidos neste experimento com os níveis de expressão dos dois receptores em rainhas, pois nesta fase de desenvolvimento ( $L 4$ para $L 5 F 1)$ as rainhas possuem títulos endógenos de HJ mais altos que operárias e de maneira contrastante elas apresentam níveis mais baixos na transcrição de $\ln R-1$ e $\ln R-2$. 


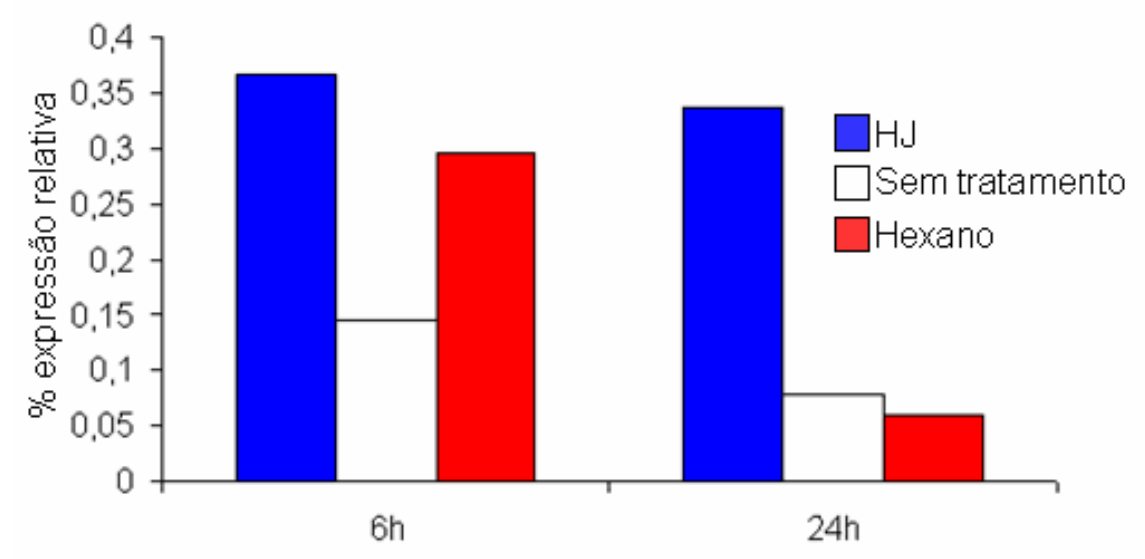

Figura 27: Transcrição de InR1 em amostras de larvas de operárias com três dias, após eclosão, tratadas com o análogo do $\mathrm{HJ}$, pyriproxifen (PPN). As amostras foram analisadas 6 horas e 24horas após o tratamento, sendo que os níveis observados em 6 horas pós-tratamento foram considerados efeitos da manipulação. As amostras foram calibradas com $\triangle \mathrm{CT}$ para o InR1 de larvas com 2horas sem tratamento (não ilustrado)

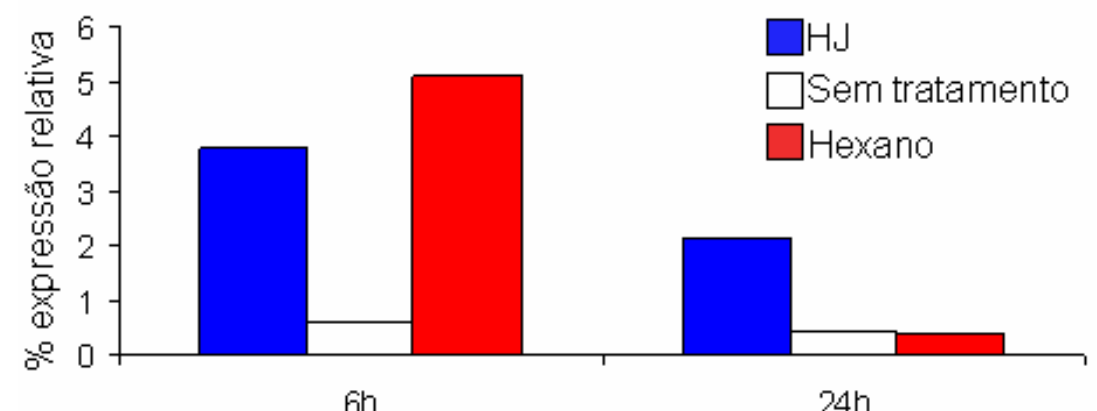

Figura 28: Transcrição de InR-2 em amostras de larvas de operárias com três dias, após eclosão, tratadas com o análogo do HJ, pyriproxifen (PPN). As amostras foram analisadas 6 horas e 24horas após o tratamento, sendo que os níveis observados em 6 horas pós-tratamento foram considerados efeitos da manipulação. As amostras foram calibradas com $\triangle \mathrm{CT}$ para o InR2 de larvas com 2 horas sem tratamento (não ilustrado)

4.2.2.4 Efeito da dieta sobre a transcrição dos genes InR1 e InR2 em operárias adultas

Abelhas operárias recém emergidas foram mantidas sob diferentes regimes de alimentação e foram coletadas em seguida para análises por qRT-PCR dos perfis de transcrição de InR1 e InR2 no quarto, sexto, oitavo e décimo primeiro dia do tratamento (Figura 29 e 30). Como calibrador de todas as amostras de operárias 
(Figuras 29 e 30) foi utilizado o valor $\Delta C T$ do gene InR1 de amostras de um dia mantidas na colméia (estágio não representado nos gráficos).

Analisando o perfil de transcrição do gene InR1 (Figura 29) notamos que no quarto dia de tratamento os níveis de transcrição foram semelhantes nas abelhas alimentadas com mel e geléia real, enquanto que nas abelhas mantidas na colméia o nível era um pouco mais elevado. No sexto dia de tratamento houve um aumento no nível de transcrição do gene InR1 para todos os tratamentos, sendo que as abelhas alimentadas com mel e as mantidas na colméia possuíam níveis de transcrição maiores e similares. No oitavo dia houve uma queda nos níveis de transcrição do gene $\operatorname{lnR} 1$, especialmente, nas abelhas alimentadas exclusivamente com geléia real ou mel. No décimo primeiro dia notamos um aumento considerável na transcrição do gene $\operatorname{InR} 1$ nas abelhas que receberam somente mel como alimento. Analisando o perfil de transcrição do gene codificador para InR-2 (Figura 30) verificamos uma similaridade geral entre a modulação da transcrição do transcrito $\operatorname{lnR}-2$ com a do transcrito $\operatorname{lnR}-1$ (Figura 29), a única diferença entre os dois receptores se manifestando no quarto dia do tratamento.

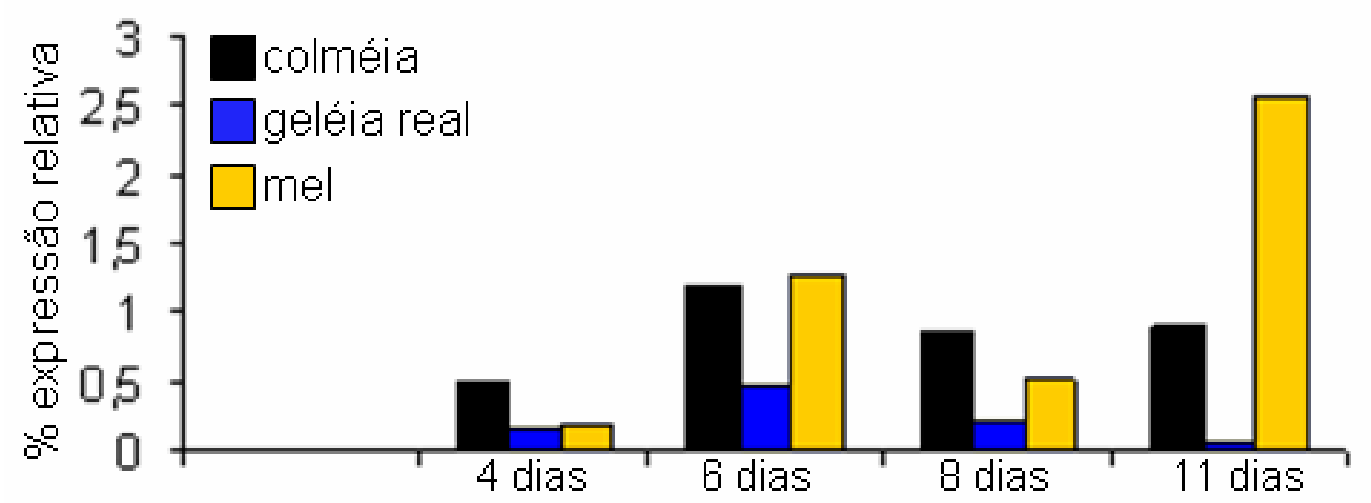

Figura 29: Transcrição de InR-1 em amostras de operárias adultas mantidas em diferentes regimes de alimentação. Como calibrador utilizamos o valor $\Delta C T$ do gene InR1 de amostras de um dia mantidas na colméia (estágio não representado nos gráficos). 


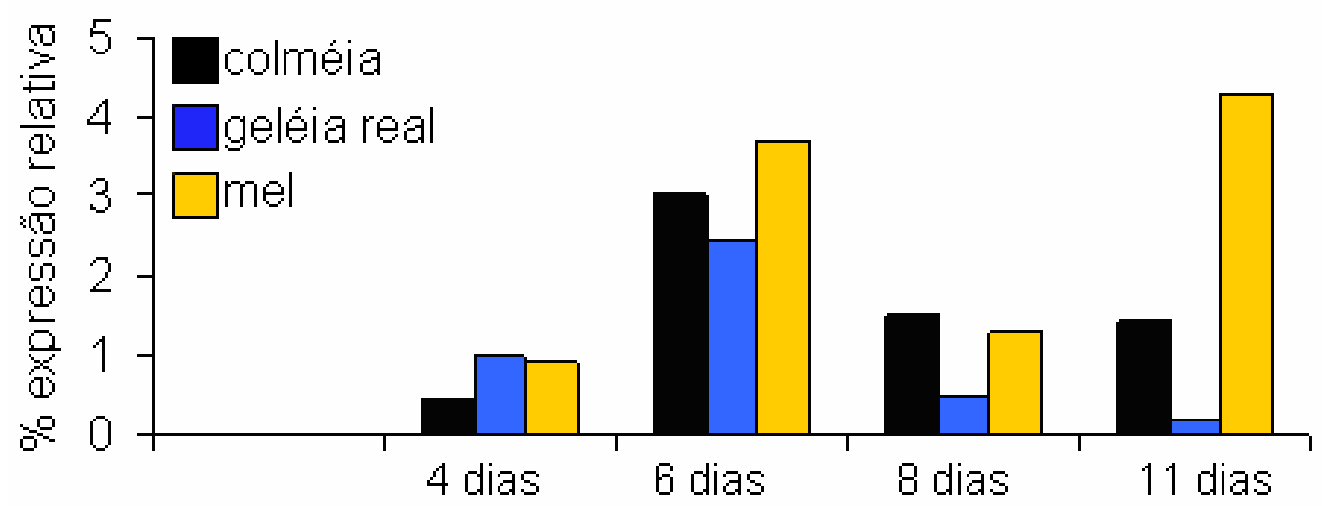

Figura 30: Transcrição de InR-2 em amostras de operárias adultas mantidas em diferentes regimes de alimentação. Como calibrador utilizamos o valor $\Delta \mathrm{CT}$ do gene InR1 de amostras de um dia mantidas na colméia (estágio não representado nos gráficos).

Para verificar a influência de uma alimentação rica em proteína sobre a transcrição dos genes codificadores do receptor de insulina, abelhas operárias foram mantidas sob uma alimentação especialmente rica em proteína (bee bread). Os perfis de transcrições dos dois receptores $\ln R 1$ e $\ln R 2$ demonstraram resultados divergentes, sendo que o gene $\operatorname{lnR} 1$ teve um aumento na sua transcrição em relação ao controle (abelhas mantidas na colméia) no quarto e no oitavo dia (Figura 31), enquanto que o gene $\operatorname{lnR2}$ teve uma leve diminuição na sua transcrição no quarto dia e se igualou no oitavo dia à transcrição observada nas abelhas mantidas na colméia (Figura 32), o que indica que a quantidade protéica no alimento representa um estímulo mais forte para a transcrição do gene $\ln R 1$ do que para o gene InR2. Como calibrador foi utilizado o $\Delta \mathrm{CT}$ de amostras da colméia de 1dia (não representado no gráfico). 


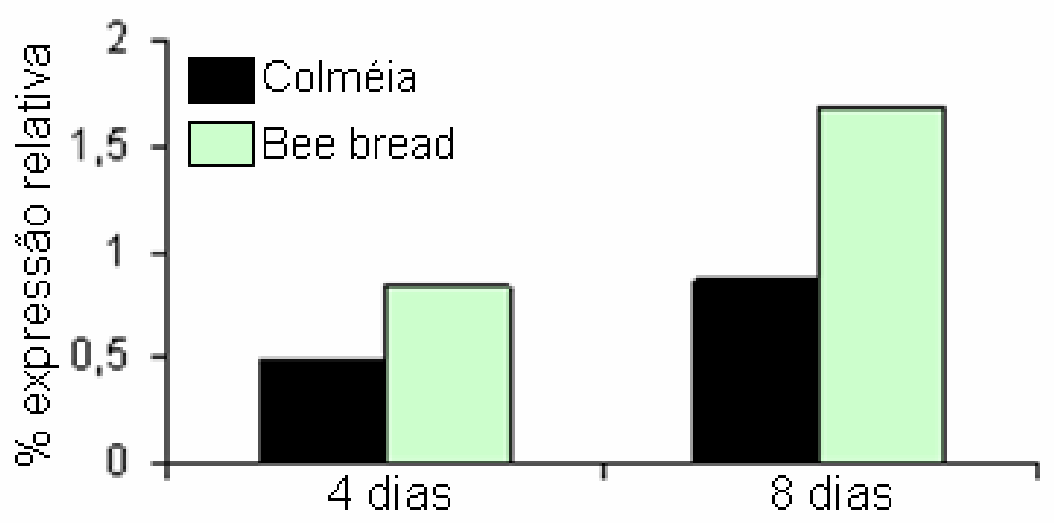

Figura 31: Transcrição de InR1 em operárias mantidas na colméia e operárias mantida sob alimentação com bee bread (rico em proteínas). Como calibrador foi utilizado o $\Delta \mathrm{CT}$ de amostras da colméia de 1dia (não representado no gráfico).

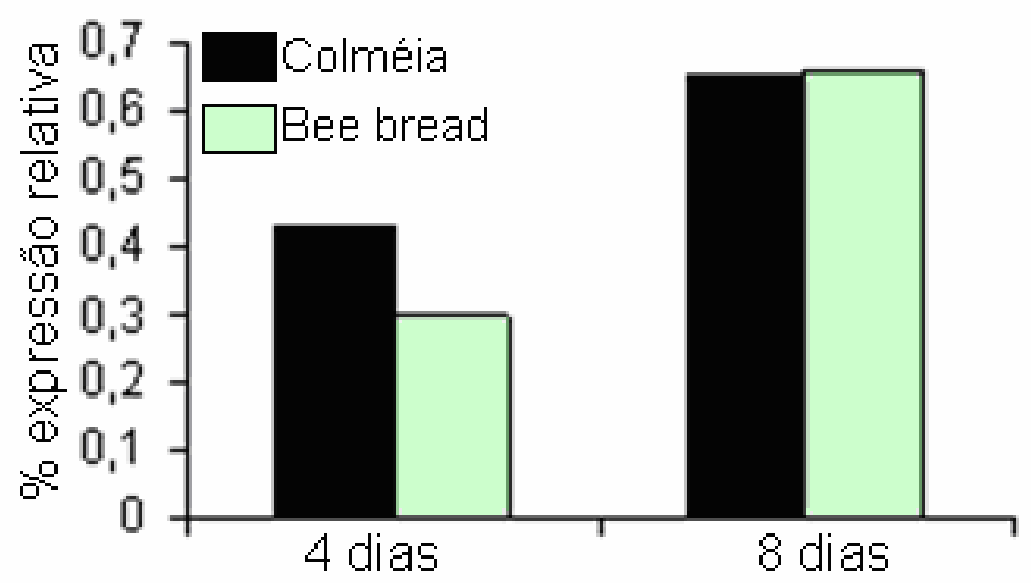

Figura 32: Transcrição de InR2 em operárias mantidas na colméia e operárias mantidas sob alimentação com bee bread (rico em proteínas). Como calibrador foi utilizado o $\Delta \mathrm{CT}$ de amostras da colméia de 1 dia (não representado no gráfico).

Os padrões transcricionais dos genes $I n R 1$ e $I n R 2$ demonstraram que ambos os genes são modulados de maneira semelhante ao longo da vida adulta das operárias, diferindo apenas, no décimo terceiro dia e no décimo quinto dia. Quanto ao nível de $I n R 2$, este ultrapassou o nível de $I n R 1$, enquanto que durante todos os outros períodos o nível de transcrição do $\operatorname{lnR} 1$ foi levemente maior ou igual ao do InR2 (Figura 33). 


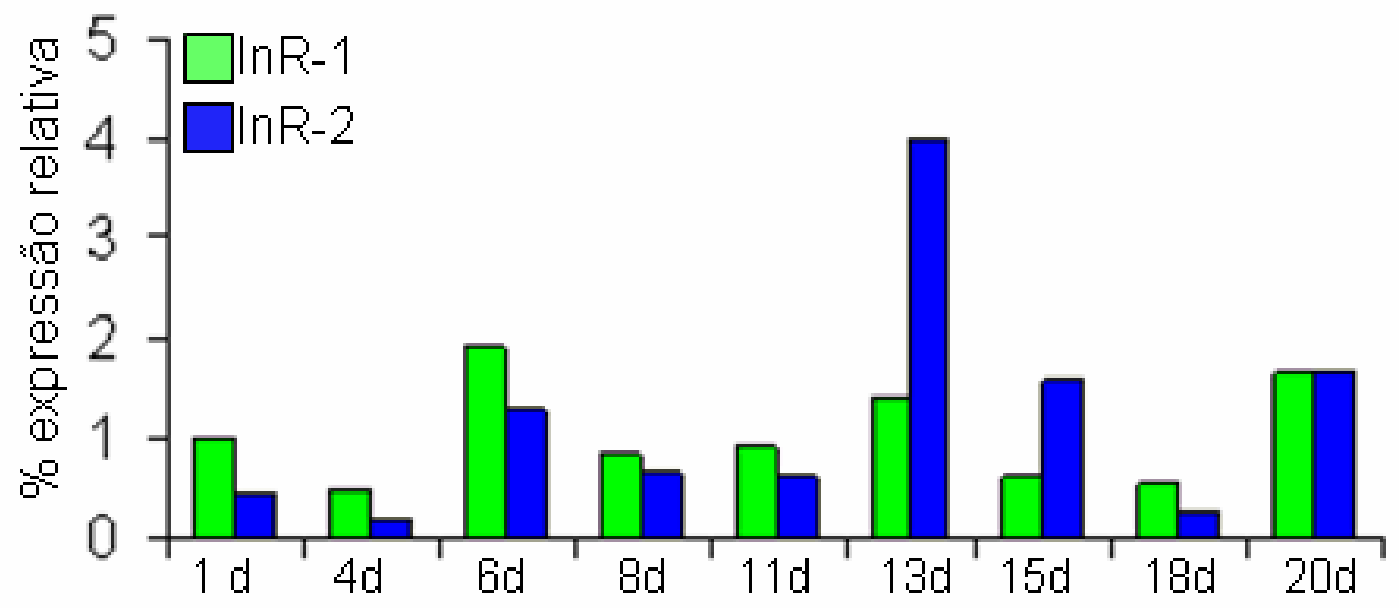

Figura 33: Transcrição de InR1 e InR2 em amostras de operárias adultas. As amostras foram calibradas para o $\Delta$ CT de InR1 das amostras de um dia.

\subsection{3'RACE do gene InR2 (GB18331)}

Durante a anotação dos genes da via IIS realizada pelo consórcio do sequenciamento do genoma da abelha (The Honeybee Genome Sequencing Consortium, 2006) surgiram dúvidas quanto a predição da região 3' do gene InR-2. Esta predição resultou em uma cauda 3' de extensão similar a de Drosophila melanogaster (Ruan et al., 1995) que foi considerada excepcionalmente longa quando comparado aos ortólogos em outros organismos. Para verificar a predição desta região empregamos um protocolo 3'RACE utilizando como âncora um primer interno da região tirosina quinase (IR2-F) e um primer oligo(dT).

Após otimização das condições do protocolo RT-PCR conseguimos amplificar um produto com cerca de $3500 \mathrm{pb}$, o que corresponderia ao tamanho predito para este fragmento do gene InR2 (GB18331) (Figura 34A). Esse fragmento foi clonado em vetor pGEM T-Easy e a inserção dele foi verificada por digestão com EcoRI (Figura 34B). Embora ainda não tenha sido possível sequenciar o fragmento de aproximadamente $3500 \mathrm{pb}$ contendo a região 3' do gene InR2, o tamanho do 
fragmento, por si só, é um forte indicador de que a predição, provavelmente, esteja correta.

A

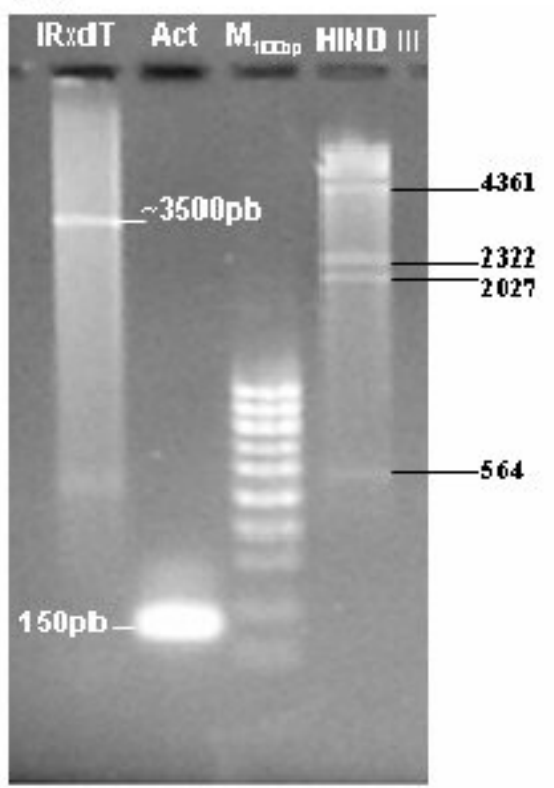

B

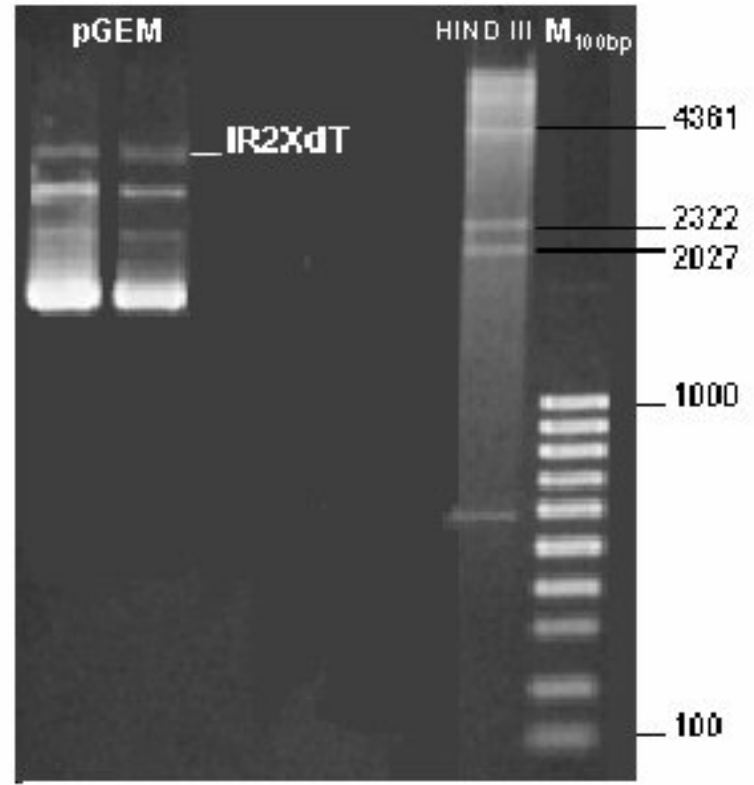

Figura 34: 3'-RACE para confirmação da região 3' do gene InR2. A) Resultado de amplificação de fragmento de aproximadamente 3500 pb; B) Digestão com EcoRI mostrando inserção deste fragmento (InRxdT) em plasmídeo pGEM T-Easy. 


\section{Discussão}

A diferenciação das castas em abelhas é um clássico caso de determinação nutricional de fenótipos alternativos: rainhas e operárias. Baseado na informação que a sinalização através da via IIS é importante na integração da nutrição e do metabolismo em uma grande variedade de organismos (Nijout 2003), nós identificamos, anotamos, validamos e sequenciamos parcialmente alguns dos genes envolvidos na via IIS da abelha melífera. Dentre os genes estudados nesse trabalho, estão os genes codificadores para os receptores de insulina InR1 e InR2, para Chico, codificador do substrato do receptor de insulina, para a quinase da proteína ribossomal, S6K, para TOR e para a proteína Tuberous sclerosis-1 (Tsc1).

Os genes para os receptores de insulina InR1 e InR2 foram investigados de forma mais aprofundada, pois, além de serem anotados e parcialmente seqüenciados, tiveram seus perfis de transcrições verificados, no intuito de determinar se eles são diferencialmente regulados durante o desenvolvimento de operárias e rainhas. A investigação desse trabalho foi focada nos terceiro, quarto e quinto estágios larvais, período no qual diferenças nutricional e hormonal podem afetar o desenvolvimento de castas.

Além do mais, também foi verificada a transcrição dos genes para os receptores de insulina em amostras de operárias tratadas com o análogo do hormônio juvenil, em ovários de operárias e rainhas (análise tecido-específica) e em operárias adultas mantidas sob regimes alimentares diferentes. Uma análise mais afundada demonstrou que o InR2 possui uma região 3 ' estendida, a qual foi verificada por 3'RACE. 


\subsection{Os receptores de insulina de Apis mellifera}

A via de sinalização por insulina (IIS) é uma das principais vias que integra o desenvolvimento geral de animais com as suas condições nutricionais. Com o sequenciamento completo do genoma de Apis mellifera foi possível anotar genes integrantes desta via, e notou-se que a abelha melífera possui no seu genoma dois genes codificadores de receptores de insulina, InR1 (GB15492) e InR2 (GB18331).

Os receptores para insulina e IGF são receptores tirosina-quinase. Eles são homodímeros de uma proteína com subunidades $\alpha$ (extracelular que se liga ao ligante insulínico) e $\beta$ (intracelular com atividade tirosina-quinase), que são clivadas e unidas por pontes disulfídicas. Em Drosophila há a ocorrência de apenas um único receptor de insulina no genoma, o qual se liga tanto à insulina quanto aos IGFs (Figura 35). Em Apis mellifera verificamos a ocorrência de dois genes codificadores para receptor de insulina, InR1 (GB15492) e InR2 (GB18331), o que nos leva a supor possíveis diferenças em suas funções, tal como ocorre em mamíferos onde também há dois receptores para a via insulina/IGF (Figura 35). Experimentos com ratos mutantes verificaram uma dicotomia na função fisiológica para o receptor de insulina e para o receptor de IGF, onde um deles está mais relacionado com a função metabólica e o outro com a função de crescimento e proliferação celular. (Kim \& Accili 2002) (Figura 35). 
A)

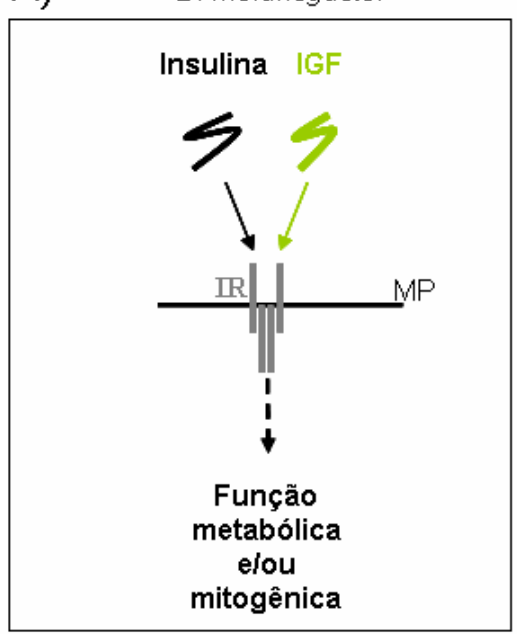

B)

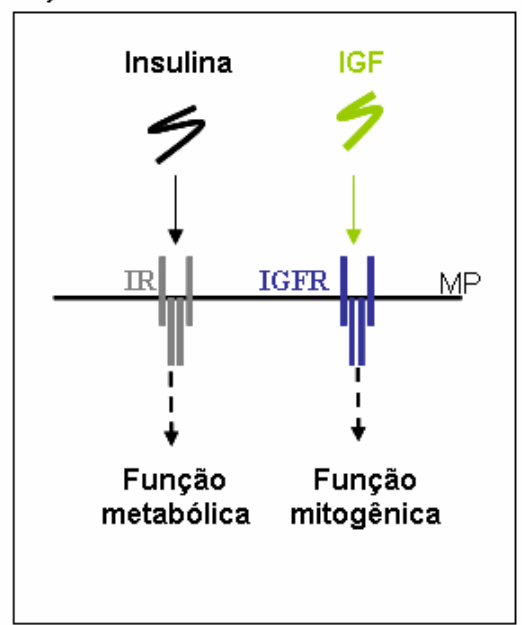

C) A. meilifera

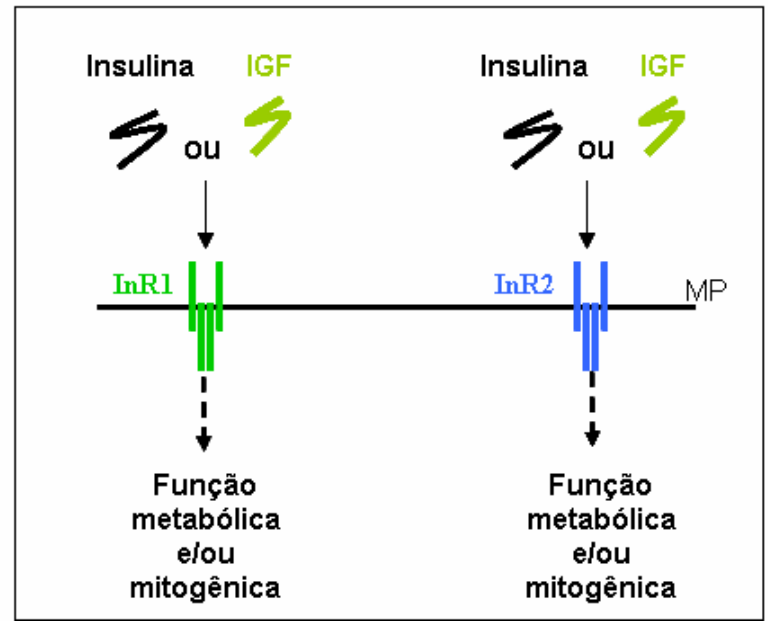

Figura 35: Esquema do receptor de insulina/IGF: A) Drosophila melanogaster, onde um único receptor desempenha as funções relacionadas ao metabolismo e ao crescimento e proliferação celular. B) Mamíferos onde há dois receptores que desempenham funções distintas (Kim \& Accili 2002). C) A. mellifera que apresenta dois receptores de insulina, mas suas funções ainda não estão determinadas. MP= membrana plasmática.

\subsubsection{Expressão dos receptores de insulina na fase larval}

As análises por RT-PCR quantitativa da transcrição dos genes InR1 e InR2 nas amostras de corpo inteiro, de larvas de rainhas e operárias, durante o período crítico da troca de alimentação para as duas castas, nos mostrou um interessante e complexo padrão de transcrição para ambos os genes (ver Figuras 23 e 24). 
Em larvas de rainhas, onde não ocorre a troca de alimentação, isto é, as mesmas continuam recebendo GR, há uma nítida diferença entre os níveis de transcrição dos genes $\ln R 1$ e InR2 no terceiro estágio larval, onde a transcrição do gene InR1 foi cerca de dez vezes maior que a transcrição do InR2. Já na fase L4 de rainhas ocorreu um decréscimo na transcrição do gene $I n R 1$, que seguiu em níveis semelhantes ao do transcrito InR2, mas com um padrão de transcrição oposto, onde o pico de um correspondia ao vale do outro (Figura 23). Esse padrão de transcrição sugere a existência de um evento entre L3 e L4 que seja independente da troca de alimentação, uma vez que a mesma não ocorre em rainhas, ou que haja alguma mudança na composição da GR que possa explicar o perfil da transcrição de ambos os genes. Haydak (1970) afirma que larvas de rainha acima de três dias recebem uma geléia real (GR) com maior conteúdo da secreção branca das glândulas hipofaríngeas, enquanto as larvas com quatro ou mais dias recebem uma GR que contém maior porcentagem da secreção clara. O composto claro possui $110,5 \mathrm{mg} / \mathrm{g}$ de proteína enquanto que o composto branco possuí 140,5 mg/g de proteína (Haydak 1970). O fato do gene InR1 ser mais transcrito que InR2 durante o estágio L3 de rainha, pode estar relacionado a essa maior concentração de proteína verificada no conteúdo da GR, corroborando com a observação em operárias adultas tratadas com bee bread, uma alimentação rica em proteína, onde observamos um aumento da transcrição apenas do gene InR1 nas abelhas alimentadas com bee bread (ver Figuras 31 e 32). Essas observações evidenciam uma maior susceptibilidade na regulação da transcrição do gene InR1 ao conteúdo de proteínas

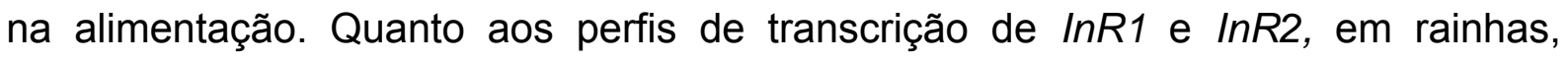
apresentarem comportamentos opostos durante as fases subseqüentes a L3 até o início da fase de tecelagem do casulo (L5S1), quando os níveis se igualaram (Figura 
23), leva-nos a crer que os dois genes são regulados de maneiras diferentes, e provavelmente correlacionados, pois o pico do perfil de transcrição de um gene corresponde ao vale do outro. O fato de Drosophila melanogaster, o modelo mais bem estudado para a via IIS em insetos, possuir apenas um receptor de insulina, e não dois como a abelha melífera, não ajuda a preencher algumas lacunas sobre essa regulação, pois faltam ainda informações sobre a maneira de ocorrência dessa regulação.

Em larvas de operárias, a troca de alimentação ocorre a partir do terceiro dia, na transição das fases larvais L3 para L4. A partir daí, elas deixam de receber GR e passam a receber geléia de operária (GO), uma mistura de secreções glandulares suplementadas com pólen e néctar. Verificamos que ocorre um aumento nos níveis dos transcritos de ambas as formas de receptor de insulina (ver Figura 24). Esse aumento pode dever-se a algum composto na GO que estimule a transcrição de ambos os genes.

Enquanto nos resultados apresentamos os perfis de transcrição dos dois receptores, separados para rainhas e operárias, olhamos estes perfis agora sob outro ângulo, o das diferenças relacionadas às castas, e comparamos os níveis de transcrição do gene InR1 nas amostras de corpo inteiro de operárias e rainhas (Figura 36). Observamos que a partir do momento onde ocorreu a troca de alimentação entre rainhas e operárias, houve uma inversão nos perfis de transcrição. O perfil do transcrito InR1, que em L3 possuía um nível de transcrição maior em rainhas do que em operárias, passou a ser maior em operárias a partir de L4 até a última fase analisada (L5S1). Em operárias, os níveis de transcrição do gene InR1 aumentam até o término da fase de alimentação, decaindo na fase de tecelagem do casulo (fase que encerra o período de alimentação em operárias). Tal resultado 
pode dever-se a algum fator da GO que induziu a transcrição do gene $\ln R 1$ e que não está presente na GR, dessa maneira, quando cessou a alimentação da operária, também interrompeu a estimulação pelo suposto fator presente na GO.

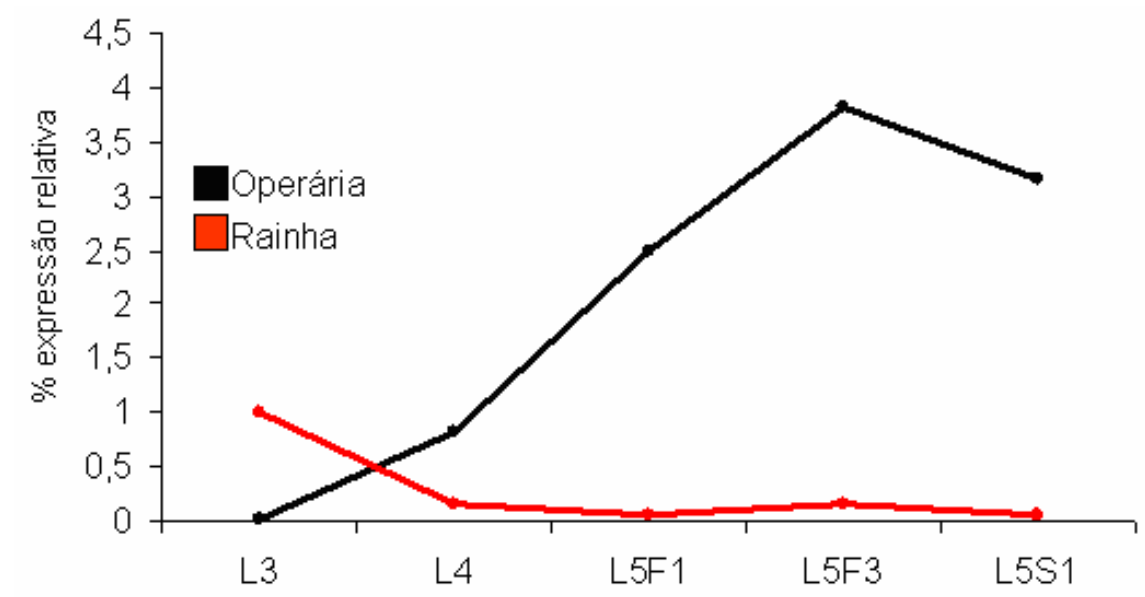

Figura 36: Perfis de transcrição do gene InR1 (GB15492), obtidos por RTPCR quantitativa, em larvas de operárias e rainhas durante o período de desenvolvimento onde ocorre a troca de alimentação entre operárias e rainhas ( $3^{\circ}$ instar) até o inicio da fase de tecelagem do casulo (L5S1). Como calibrador foi utilizado o $\Delta$ CT de rainhas L3.

Analisando a transcrição do gene InR2 em amostras de corpo inteiro de larvas de operárias e rainhas, em uma mesma escala (Figura 37), observamos que os níveis de transcrição são baixos e similares durante o terceiro instar larval, corroborando com os dados de Wheeler e colaboradores (2006). No entanto, após o terceiro instar larval, inicia-se uma dicotomia entre os dois perfis. O nível dos transcritos $\operatorname{lnR} 2$ em operárias aumenta, principalmente a partir de L4, enquanto os níveis de transcrição do gene InR2 em rainhas mantêm-se baixos, atingindo seus menores níveis em L5F3 e L5S1, quando ocorre o término da fase de alimentação e início da fase de tecelagem do casulo. Essa dicotomia observada, provavelmente deve-se à troca do alimento de operária, e reforça a nossa hipótese da presença de algum fator na geléia de operária que induz a transcrição do receptor de insulina. 


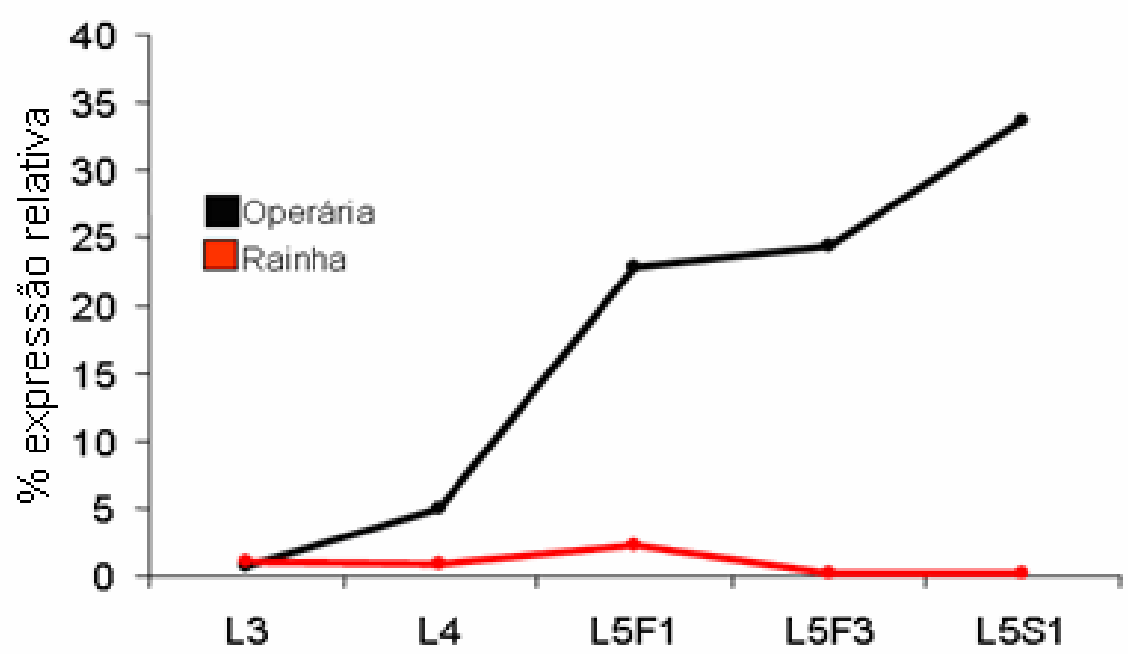

Figura 37: Perfis de transcrição do gene InR2 (GB18331), obtidos por RTPCR quantitativa, em larvas de operárias e rainhas durante o período de desenvolvimento onde ocorre a troca de alimentação entre operárias e rainhas ( $3^{\circ}$ instar) até o inicio da fase de tecelagem do casulo (L5S1). Como calibrador foi utilizado o $\Delta C T$ de rainhas $L 3$.

\subsubsection{Expressão dos receptores de insulina no ovário larval}

As análises das amostras de corpo inteiro de larvas de operárias e rainhas nos mostraram que houve uma modulação diferente na transcrição dos dois receptores de maneira geral. No intuito de entender melhor a maneira como as transcrições dos dois receptores comportam-se de forma tecido-específica, e tentar relacionar os dois receptores com funções especificas como proliferação celular e metabolismo, foram analisadas, por qRT-PCR, amostras de ovários de rainhas e operárias (ver Figuras 25 e 26) em fases onde sabidamente há diferenças quanto ao seu desenvolvimento (L4, L5F3, L5S1, L5S3 e PP1). A diferenciação casta específica do ovário começa no último instar larval, quando há a formação de clusters por mitoses simultâneas e incompletas no ovário de rainha, enquanto nos ovários das operárias a característica predominante é a morte celular programada (Schmidt Capella \& Hartfelder 1997; Reginato \& Cruz-Landim 2003; Tanaka et al., 2006). Somente na fase prépupal, quando a cápsula do ovário desaparece, é que as 
diferenças entre os ovários de rainha e operária se tornam mais visíveis (Reginato \& Cruz-Landim 2003).

Olhando os eventos que ocorrem durante o desenvolvimento dos ovários nas duas castas, é difícil estabelecer uma relação apenas com os dados disponíveis para os perfis de expressão dos genes $\operatorname{lnR} 1$ e InR2. No entanto, devido ao papel já conhecido da via IIS nos ovários de outros organismos, acreditamos que há um possível envolvimento desta via com o desenvolvimento dos ovários de operárias e rainhas de Apis mellifera. Drummond e Spradling (2001) verificaram que moscas mutantes para o gene Chico apresentavam deficiência no desenvolvimento do ovário. Richard e colaboradores (2005) verificaram que o gene Chico, substrato do receptor de insulina, é necessário para o progresso da vitelogênese em ovários de Drosophila melanogaster. Assim, afim de obter novas informações, exploramos os nossos resultados obtidos por RT-PCR quantitativa de maneira diferente, comparando os perfis de transcrição dos genes InR1 e InR2 entre as duas castas (Figuras 38 e 39). A transcrição do gene InR1 em ovários de rainhas seguiu em níveis basais até a fase prépupal, quando ocorreu um expressivo aumento na transcrição do gene InR1, enquanto nos ovários de operárias houve um padrão de aumento mais gradual na transcrição do gene InR1 até a fase PP1, sendo que os níveis dos transcritos InR1 foram sempre maiores em operárias que em rainhas. (Figura 38). Para o gene codificador de InR2 observamos que o mesmo foi expresso em altos níveis em ovários de operárias, com relação aos ovários de rainhas, apenas em L4, enquanto os níveis de transcrição de rainhas superaram os de operárias em L5F3 e L5S3, e nas outras fases ambos os níveis foram baixos ou com apenas pequenas variações (Figura 39). 
Olhando os perfis de transcrição dos receptores de insulina de maneira comparativa entre as castas, verificamos que há diferenças nos padrões de transcrição dos dois genes e que, provavelmente, há o envolvimento de um, ou dos dois genes codificadores do receptor de insulina na diferenciação do ovário. Além dessas diferenças observadas por nós, estudos em Drosophila revelaram que a oogênese sofre influência dos níveis de nutrientes e que a sinalização via IIS desempenha um papel em detectar e controlar a taxa de crescimento em células do ovário (Drummond \& Spradling. 2001).

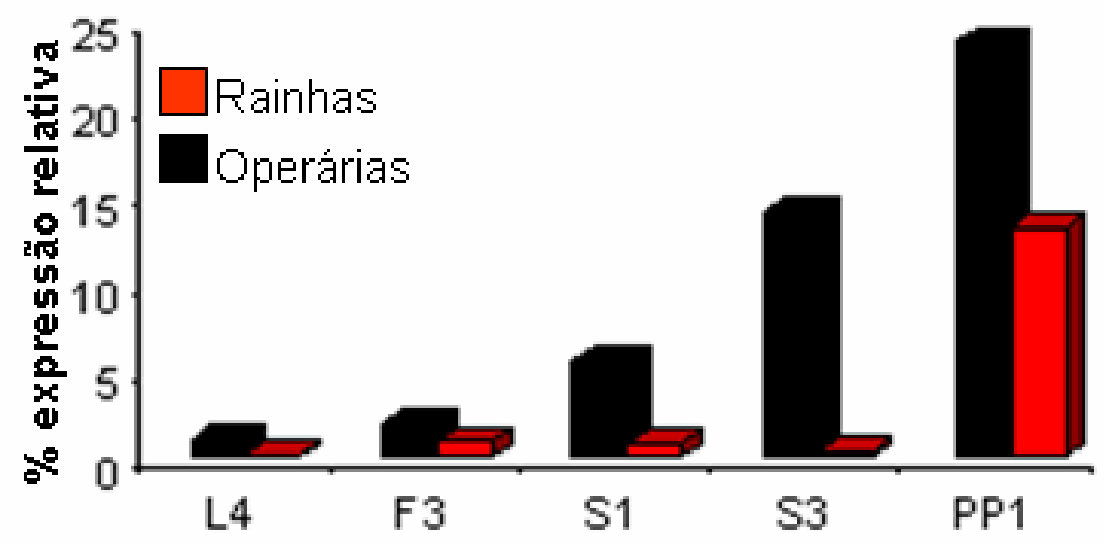

Figura 38: Perfis de transcrição do gene InR1 (GB15492), obtidos por RTPCR quantitativa, em ovários de larvas de operárias e rainhas durante estágios nos quais os ovários se desenvolvem diferentemente em cada casta. Como calibrador foi utilizado o $\Delta C T$ de operárias L4. 


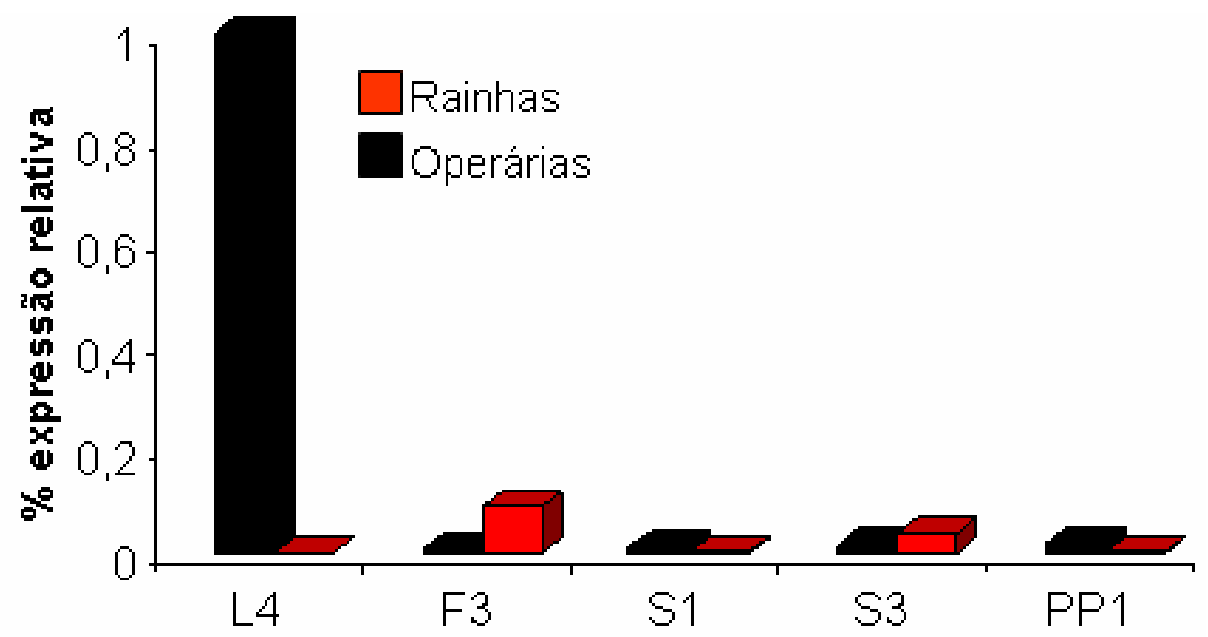

Figura 39: Perfis de transcrição do gene InR2 (GB18331), obtidos por RTPCR quantitativa, em ovários de larvas de operárias e rainhas durante estágios nos quais os ovários se desenvolvem diferentemente em cada casta. Como calibrador foi utilizado o $\Delta \mathrm{CT}$ de operárias L4.

\subsubsection{Efeito de hormônio juvenil sobre a transcrição de InR1 e InR2}

Como há anos vêm se imaginando que a expressão de fenótipos alternativos em insetos depende de fatores ambientais, os quais se traduzem em respostas específicas do sistema endócrino (para revisão ver Goewie 1978; Dingle \& Winchell 1997; Hartfelder 2000a; Hartfelder 2000b; Hartfelder \& Emlen 2005), tratamos larvas de abelhas com três dias de vida com o análogo do hormônio juvenil PPN (pyriproxifen), e analisamos a transcrição de $\ln R 1$ e $\ln R 2$ seis e vinte e quatro horas após o tratamento (Figuras 27 e 28). Os resultados com seis horas de tratamento foram considerados efeito da manipulação, pois, pelo protocolo experimental, o quadro contendo as larvas tratadas teve que ficar fora da colméia, por pelo menos duas horas para garantir e evaporação completa do solvente. Já em vinte e quatro horas após o tratamento, observamos, para ambos os transcritos $\ln R 1$ e $\ln R 2$, um aumento com relação às amostras controles. No entanto, a relação da aplicação de HJ com o aumento dos níveis de transcrição não pode ser aplicada como regra, pois ao comparar os títulos hormonais (Figura 5) aos perfis de transcrição dos genes InR1 e InR2, não observamos essa relação direta entre os títulos hormonais e os 
perfis de transcrição dos receptores de insulina em abelhas. $\mathrm{O}$ fato dos genes para os receptores de insulina responderem de uma maneira sob o tratamento com $\mathrm{HJ}$, e de outra durante o desenvolvimento organismo, elucida ainda mais a suposta complexidade na regulação da transcrição dos genes codificadores para os receptores de insulina de Apis mellifera. Por outro lado, tal complexidade não seria surpreendente, uma vez que a via IIS está relacionada a processos distintos, como regulação do envelhecimento (Tatar et al., 2001, 2003), regulação do crescimento e proliferação celular (Goberdhan \& Wilson 2003), vitelogênese (Richard et al.,2005) e desenvolvimento do ovário em moscas (Drummond \& Spradling 2001), entre outros.

\subsubsection{Efeitos da dieta sobre a expressão dos receptores de insulina}

Em Drosophila melanogaster, um único receptor se liga em até sete peptídeos similares a insulina (ILPs), controlando o crescimento celular, proliferação e o metabolismo (Goberdhan \& Wilson 2003). Já em Apis mellifera, Wheeler e colaboradores (2006) verificaram a presença de pelo menos dois peptídeos insulínicos em Apis mellifera, AmILP-1 e AmILP-2, e a análise in silico do genoma revelou a ocorrência de dois genes putativos para o receptor de insulina (Tabela 2), confirmando as análises feitas por Miguel Corona, o anotador oficial do Consórcio de Genoma de Abelha designado para este grupo de genes, que denominou os dois receptores de InR1 (GB15492) e de InR2 (GB18331), nomenclatura adotada por nós nesse trabalho. A transcrição dos dois genes codificadores para os receptores de insulina em Apis mellifera foi validada por nós, via RT-PCR (Figura 10), elucidando a ocorrência dos mRNAs para as duas proteínas.

Assim como em Apis mellifera, mamíferos também possuem dois receptores, o receptor de insulina propriamente dito e o receptor para os fatores de crescimento 
insulina-like (IGFs). Estudos em ratos mutantes apresentaram uma dicotomia funcional parcial, onde os receptores ativam distintas cascatas de sinalização, as envolvidas com o metabolismo e as levando ao crescimento celular, embora em muitos casos possa haver uma sobreposição de funções (Kim \& Accili 2002). Em Apis mellifera, essa especificidade entre as diferentes funções e os receptores, ainda não foi profundamente estudada, sendo nossos resultados sobre os perfís de transcrição dos InR1 e InR2, nas fases larvais, os primeiros a sugerirem uma provável especificidade funcional.

$\mathrm{Na}$ tentativa de estabelecer relações, semelhantes às observadas em mamíferos, para os putativos receptores de insulina em Apis mellifera, realizamos, paralelamente às análises nos ovários descritas acima (Item 5.1.3), experimentos com abelhas operárias adultas alimentadas com diferentes dietas, com a finalidade de tentar detectar se há envolvimento diferencial e, se houver, qual dos dois receptores estaria mais ligado ao estímulo nutricional. As análises por qRT-PCR da transcrição dos genes InR1 e InR2 (ver Figuras 29 e 30), demonstrou que os perfis são semelhantes para ambos os genes, sugerindo que o tipo de alimentação influencia na expressão de ambos os genes e que mecanismos intrínsecos, possivelmente ligados à idade das abelhas, possam modular o padrão de transcrição. Um ponto de destaque é o aumento na transcrição dos genes $\operatorname{lnR} 1$ e InR2 nas operárias alimentadas com mel. Esse aumento pode estar relacionado à mudança de tarefas em operárias adultas, pois, ao se prepararem para a fase campeira, a sua alimentação muda e elas passam a se alimentar principalmente de carboidratos (Crailsheim \& Stolberg 1989).

Uma análise complementar por qRT PCR, do padrão de transcrição dos genes InR1 e InR2 em operárias adultas, mantidas na colméia, durante os primeiros 
vinte dias da vida adulta (Figura 33), mostrou que o nível de transcrição do gene InR1 foi mais alto que o nível de transcrição do gene $\ln R 2$ durante quase toda a vida adulta da operária (ver Figura 33). Apenas durante o décimo terceiro e décimo quinto dia ocorreu uma inversão dos níveis, onde o nível de transcrição do gene InR2 superou o nível do de transcrição do gene InR1. Esse momento de alternância entre os níveis dos receptores pode estar relacionado com o polietismo etário.

Como nestes experimentos o nosso objetivo era apenas uma primeira investida para tentar relacionar a transcrição dos receptores de insulina com a sua idade, não fizemos análises adicionais sobre o comportamento destas abelhas, nem análises da transcrição dos genes ao longo da vida adulta de rainha. Nossos resultados revelaram efeitos da alimentação e da idade, possivelmente ligados ao polietismo etário, na transcrição dos dois receptores, merecendo investigação mais detalhada, uma vez que o desenvolvimento comportamental de operárias adultas está intrinsecamente relacionado com os títulos de $\mathrm{HJ}$ e de vitelogenina, que se integram em um circuito de regulação mútua (Amdam e Omholt 2002; Guidugli et al. 2005, Nelson et al. 2007).

\subsection{Análise da cauda 3' do gene InR2}

A análise in sílico do gene codificador para o InR2 (GB18331) (Figura 13), elucidou a existência de uma extensa seqüência na região 3' desse gene, onde não há nenhum domínio proteico conhecido. Por se tratar de um gene predito computacionalmente, considerou-se que pode ter ocorrido um erro na predição, devido à inclusão da longa extensão carboxil-terminal que ocorre no ortólogo de Drosophila melanogaster. Para Drosophila, suspeita-se que esta extensão esteja envolvida com uma importante função no papel de transdução de sinal, 
possivelmente nas interações com outras proteínas (Ruan 1995). Para validar a respectiva predição para Apis mellifera, realizamos uma 3' RACE para o gene InR2, onde obtivemos um fragmento de aproximadamente 3500pb (Figura 34), que foi clonado e aguarda o seu sequenciamento. O fato da amplificação de um fragmento de 3500pb ter ocorrido, que era o tamanho previsto, leva-nos a crer que a predição está correta, e que realmente existe uma extensão da região 3' do gene $\ln R 2$ de Apis mellifera.

\subsection{Anotação e sequenciamento outros componentes da via IIS}

Além dos genes para os receptores de insulina, estudados mais a fundo nesse trabalho, há outros componentes na via IIS que foram investigados ao longo da realização desse projeto. Alguns genes envolvidos na via de sinalização IIS previamente identificados (Tabela 2) foram selecionados, anotados com o auxílio da ferramenta computacional Artemis, analisados com ferramentas BLASTs, tiveram primers desenhados específicamente para validação de cada um deles e, adicionalmente, alguns foram seqüenciados.

\subsubsection{O substrato do receptor de insulina Chico de Apis mellifera}

O gene codificador para o substrato do receptor de insulina de Apis mellifera (GB11037), ortólogo à proteína substrato do receptor de insulina (Chico) de Drosophila melanogaster, foi identificado, anotado, seqüenciado, os domínios conservados foram evidenciados, e sua transcrição validada por RT-PCR (Figuras 9 e 16). O sequenciamento feito por nós (Figura 16) e a análise BLASTN confirmou que o observado trata-se mesmo de um ortólogo para o Chico em Apis mellifera, 
com uma similaridade de $87 \%$ em relação ao predito GB11037 (Figura 17). A similaridade entre o fragmento seqüenciado e o predito não foi maior devido a problemas no sequenciamento, embora a similaridade obtida já seja suficiente para afirmarmos que se trata do mesmo gene.

O substrato do receptor de insulina (Chico) age no sentido de propagar o sinal do receptor de insulina para a fosfoinositídeo quinase-3 (PI3K) (Yenush and White, 1997), e em Drosophila está envolvido no controle do tamanho, fertilidade da fêmea e metabolismo de lipídeos durante o desenvolvimento (Fernandez et al 1995; Chen et al. 1996, Bohni et al 1999, Brogiolo et al. 2001).

\subsubsection{A quinase ribossomal S6K de Apis mellifera}

Com relação à quinase ribossomal S6 (S6K) de Drosophila melanogaster, foi encontrado no genoma de Apis mellifera (Amel. 4.0) um gene ortólogo predito (Official_Gene_Set number accession GB19390-PA). A análise de domínios conservados por RPSBLAST demonstrou que a proteína predita de Apis mellifera possui o domínio S_TKc, que é o domínio catalítico de proteína serina/treonina quinase, e o domínio S_Tk_X, que é uma extensão do domínio S_Tk (Figura 18). A transcrição do gene predito S6K (GB19390-PA) em Apis mellifera (Figura 9) foi verificada com os primers S6K-F e S6K-R, e o fragmento obtido foi seqüenciado e analisado por ferramenta BLASTN (Figuras 18 e 19). A similaridade obtida entre o fragmento originado pelos primers S6K-F e S6K-R com o gene predito (GB19390) foi de $92 \%$, o suficiente para concluirmos que se trata do mesmo gene.

A quinase S6K ativada aumenta a fosforilação da proteína ribossomal S6, a qual controla seletivamente a translação de mRNAs de proteínas ribossomais 
através de um trato de oligopirimidina na região de início de transcrição 5' (5' TOP) (Thomas 2000). A tradução das proteínas ribossomais 5' TOP é necessária no controle do crescimento celular (Thomas 2000). Além disso, a sinalização dependente de nutriente via quinase S6K está envolvida, juntamente com a sinalização TOR, no desenvolvimento de ovos em mosquitos (Hansen et al. 2005).

\subsubsection{O gene supressor de tumor TSC-1 de Apis mellifera}

A análise in silico do gene ortólogo em Apis mellifera (Official_Gene_Set number accession GB12676-PA) para o gene Tsc1 (Tuberous sclerosis) de Drosophila melanogaster, indicou que o mesmo codifica uma proteína com os domínios Harmantina e o domínio ABC_SHC4_euk (Figura20). A proteína Tsc1 é um supressor de tumor envolvido na via de sinalização da insulina e na via de sinalização TOR (Bateman \& Neill 2004). A proteína TSC-1 inibe a atividade da quinase S6k, e a sua ausência leva a uma ativação constitutiva de S6K (Radimerski et al. 2002). A análise por RT-PCR com os primers Tsc1-F e Tsc1-R demonstrou que ocorre a presença do transcrito em larva de Apis mellifera (Figura9).

\subsubsection{O gene codificador para uma proteína alvo de rapamicina (TOR) em Apis} mellifera

Para o gene o gene TOR de Drosophila melanogaster foi verificado, em Apis mellifera, a existência de cinco preditos que são possíveis membros da família TOR (Tabela 2). Dos cinco preditos, foi escolhido um provável ortólogo em Apis mellifera (Official_Gene_Set numbers accession GB11213) que possui maior similaridade com seu correspondente em D. melanogaster (Tabela 2). O gene TOR selecionado teve sua seqüência anotada e analisada por ferramentas BLASTs. A análise dos 
domínios conservados por RPSBLAST evidenciou a presença de três domínios conservados característicos das proteínas alvos de rapamicina: um domínio PI3K relacionado $(\mathrm{PI} 3 \mathrm{Kc})$ e dois domínios FAT adicionais, um C-Terminal e outro $\mathrm{N}$ Terminal em relação ao domínio PI3K.(Figura 21). As proteínas TOR são serina/treonina quinases, que pertencem à família de quinases relacionadas à quinase fosfoinositideo-3 (PIKK), e recebem a designação de TOR por serem alvo de rapamicina (target of rapamycin) (Oldham \& Hafen 2003). Essas proteínas fazem parte de uma via de sinalização sensível à presença de aminoácidos que regula o crescimento, alterando a transcrição e tradução de genes em resposta a alterações nos nutrientes (Fafournoux et.al. 2000; Van Sluijters et al. 2000). TOR é conhecido por responder positivamente à presença de aminoácidos, e induzir um aumento na tradução através de ativação da quinase ribossomal S6 (S6K) (Dufner \& Thomas 1999, Hansen 2005). A transcrição do suposto gene TOR em Apis mellifera foi verificada por RT-PCR com o par de primers específicos (Figura 9).

\subsection{Considerações finais}

A evolução da vida social nos insetos himenópteros provavelmente contou com modificações nos mecanismos de controle que afetaram a fecundidade, que em muitos insetos estão correlacionadas com o tamanho do corpo da fêmea (Patel et al .2007). A relação entre o tamanho do corpo e fecundidade é afetada positivamente pela nutrição larval (Reiss 1989). A via de sinalização IIS, que é altamente conservada na evolução, constitui um exemplo de um mecanismo regulador chave que permite que organismos se adaptem à mudanças de nutrientes (Puig \& Tijan 2005, 2006). Dessa forma, a via IIS provavelmente está envolvida no surgimento de castas reprodutivas (operárias e rainhas) a partir dos ancestrais dos organismos sociais (sem castas), onde a plasticidade no desenvolvimento que diz respeito a 
escala de tamanho e fecundidade através da nutrição pode ter se adaptado a produzir descendentes com diferentes capacidades reprodutivas (Patel et al. 2007).

Além das características como tamanho, morfologia e fecundidade, as operárias e rainhas possuem diferenças quanto a taxas de crescimento e tempo de desenvolvimento larval e, no indivíduo adulto, longevidade. A via de sinalização IIS, por sua vez, está envolvida no controle de múltiplos processos celulares como a apoptose (Brunet et al. 1999), síntese de RNA de genes envolvidos no ciclo celular (Alvares et al. 2001), crescimento e tamanho celular (Goberdham \& Wilson 2003; Dufner \& Thomas 1999) e longevidade (Tatar et al. 2003). Assim, devido aos diferentes papéis desempenhados pela via IIS em características claramente distintas entre as duas castas de Apis mellifera, esse módulo de sinalização vem ocupando lugar como um provável integrador entre os diferentes tipos de alimentação e o desenvolvimento de castas específicas em Apis mellifera.

Nossos resultados demonstraram claramente que há diferenças entre os níveis de transcrição dos receptores de insulina $\operatorname{lnR} 1$ e $\operatorname{lnR} 2$, tanto em uma mesma casta quanto entre as diferentes castas (operárias e rainhas), pois os níveis dos transcritos InR1 e InR2 em operárias, de uma maneira geral, foram maiores do que em rainhas e que em operárias adultas há um predomínio na transcrição do gene InR1 ao longo da vida, mas que é marcado por alguns momentos onde o predomínio passa a ser do gene InR2. Além do mais, há o fato que o gene InR1 se mostrou mais sensível a uma dieta rica em proteínas do que o gene InR2 e que aparentemente existe algum fator, ainda desconhecido, na geléia de operária que mantêm os níveis de transcrição dos receptores de insulina maiores em larvas de operárias do que em larvas de rainhas. 
Os resultados observados nesse trabalho, juntamente com os dados de Wheeler e colaboradores (2006), Seehus e colaboradores (2006), e Patel e colaboradores (2007) constituem as primeiras informações sob as relações entre a via IIS e as diferentes castas observadas em Apis mellifera. Embora muito ainda tenha que ser feito, no sentido de buscar a compreensão das relações moleculares da via IIS com os diferentes estímulos nutricionais aos quais as larvas das abelhas submetem-se, são possíveis análises comparativas entre o genoma de Apis mellifera e os genomas de diferentes invertebrados como Caenorhabditis elegans, Aedes aegypti, Anophleles gambiae, Bombyx mori e Tribolium castaneum, disponíveis no banco de dados NCBI (http://www.ncbi.nlm.nih.gov/Genomes/). Essas análises comparativas serão úteis no sentido de buscar peculiaridades e semelhanças entre as vias de sinalização IIS dos diferentes organismos, como o fato de em C. elegans haver 37 genes codificando peptídeos insulínicos, enquanto em $D$ melanogaster tem 7 peptídeos insulínicos, sendo que em ambos os organismos há um único receptor de insulina (The Honeybee Genome Sequencing Consortium 2006). Por outro lado, em Apis mellifera há apenas dois genes codificadores de peptídeos insulínicos identificados (AmILP-1 e AmILP-2), assim como, há dois receptores de insulina (InR-1 e InR-2) (The Honeybee Genome Sequencing Consortium 2006). Dessa maneira, associando as análises genômicas com as metodologias disponíveis para Apis mellifera, será possível elucidar as relações genéticas e moleculares da via de sinalização IIS particular de $A$. mellifera, que resultam na distinção entre operárias e rainhas. 


\section{Conclusão}

As análises realizadas e os resultados obtidos ao longo do desenvolvimento desse trabalho permitiram as seguintes conclusões:

- Ortólogos de importantes genes da via de sinalização IIS (InR1, InR2, TOR, TSC1, S6K e Chico) são transcritos em Apis mellifera, comprovando a conservação dessa via em organismos filogeneticamente distintos como $A$. mellifera, D. melanogaster, H. sapiens e M. musculus.

- Existem dois genes para os receptores de insulina, InR1 e InR2, que são transcritos ao longo da vida da abelha Apis mellifera de maneira casta específica

- A transcrição dos genes codificadores para os receptores de insulina, InR1 e InR2, apresenta perfis tecido-específicos, com relação às amostras de ovários quando comparadas às amostras de corpo inteiro para ambas as castas.

- Os níveis dos transcritos InR1 e InR2 são maiores em larvas de operárias do que em larvas de rainhas, fato que pode estar relacionado com a dieta das operárias. 
- A transcrição de InR1 apresentou uma modulação maior que a de InR2 em resposta a dietas na fase adulta de operárias, indicando funcionalidades diferentes dos dois receptores.

- A regulação da expressão dos genes codificadores para os receptores de insulina InR1 e InR2 é complexa, sendo influenciada por fatores genéticos e ambientais. 


\section{Bibliografia}

Alvarez, B., Martinez, A.C., burgering, B.M., Carrera, A.C. (2001). Forkhead transcription factors contribute to execution of the mitotic programme in mammals. Nature 413, 744-747.

Amdam, G. V. \& Omholt, S. W. (2002). The regulatory anatomy of honeybee lifespan. Journal of theoretical biology 216. 209-228.

Barron, A. B., Oldroyd, B.P., RAtnieks, F.L.W. (2001) Worker reproduction in honeybees (Apis) and the anarchic syndrome: a review. Behavioral Ecology and Sociobiology 50,199-208.

Bateman, J.M. \& McNeill, H (2004) Temporal control of differentiation by the insulin Receptor/Tor Pathway in Drosophila. Cell 119, 87-96.

Bohni, R., Riesgo.-Escovar, J., Oldham, S., Brogiolo, W., Stocker, H., Andruss, B.F., Beckingham, K., Hafen, E. (1999) Autonomous control of cell and orgam size by CHICO, a Drosophila homolog of vertebrate IRS1-4. Cell 97, 865-875.

Brogiolo, W., Stocker, H., Ikeya, T., Rintelen, F., Fernandez, R., Hafen, E. (2001) An evolutionarily conserved function of the Drosophila insulin receptor and insulinlike peptides in growth control. Current Biology 11, 213-221.

Brunet, A., Bonni, A., Zigmond, M.J., Lin, M.Z., Juo, P., Hu, L.S., Anderson, M.J., Arden, K. C., Blenis, J., Greenberg, M.E. (1999). Akt promotes cell survival by phosphorylating and inhibiting a Forkhead transcription factor. Cell 96, 854-868.

Chen, C., Jack, J., Garofalo, R.S. (1996) The Drosophila insulin receptor is required for normal growth. Endocrinology 137, 846-856. 
Colombani, J., Bianchini, L., Layalle, S., Pondeville, E., Dauphin-Villemant, C., Antonieweski, C., Carré, C., Noselli, S., e Léopold, P. (2005) Antagonistic actions of Edysone and Insulin determine final size in Drosophila. Science,310, 667-670.

Crailsheim, K. \& Stolberg, E. (1989). Influence of diet, age and colony condition upon intestinal proteolytic activity and size of the hypopharyngeal glands in the honeybee (Apis mellifera L.). Journal of Insect Physiology 35 (8), 595-602.

Dedej, S., Hartfelder, K., Aumeier, A., Rosenkranz, P., Engels, W. (1998) Caste determination is a sequential process: effect of larval age at grafting on ovariole number, hind leg size and cephalic volatiles in the honey bee (Apis mellifera). Journal of Apicultural Research 37 (3), 198-190.

De Kort, C.A.D. \& Granger, N.A. (1996) Regulation of JH titers: The relevance of degradative enzymes and binding proteins. Archives of insect biochemistry and Physiology 33, 1-26.

Dietz, A., Herman, H.R., Blum, M.S. (1979) The role of exogenous JH I, JH II, JH III and anti-JH (precocene II) on queen induction of 4.5-day-old worker honeybee larvae. Journal of Insect Physiology 25, 503-512.

Dingle, H. \& Winchell, R. (1997). Juvenile hormone as a mediator of plasticity in insect life histories. Archives of Insect Biochemistry and Physiology 35, 359373.

Dufner,A. \& Thomas, G.(1999). Ribossomal S6 kinase signaling and the control of translation. Experimental Cell Research 253, 100-109.

Drummond, D.B. \& Spradling, A.C. (2001) Stem Cells and Their Progeny Respond to Nutrional Changes during Drosophila Oogenesis. Developmental Biology 231, 265-278. 
Evans, J. D. \& Wheeler, D. E. (2000). Expression profiles during honeybee caste determination. Genome Biology 2 (1), 1-6.

Fafournoux, P., Bruhat, A. Jousse, C. (2000) Amino acid regulation of gene expression. Biochemical Journal 351, 1-12.

Fernandez, R., Tabarini, D., Azpiazu, N., Frasch, M., Schlessinger, J. (1995) The Drosophila insulin receptor homolog: a gene essential for embryonic development encodes two receptor isoforms with different signaling potential. EMBO Journal 14, 3373-3384.

Garrett, T.P.J., McKern, N. M., Lou, M., Frenkel, M.J., Bentley, J.D., Lovrecz,G.O., Elleman,T.C., Cosgrove, L.J., Ward, C. W. (1998) Crystal structure of the first three domains of the type-1 insulin-like growth factor receptor. Nature 394, 395399.

Goberdhan, D.C.I. \& Wilson, C. (2003) The functions of insulin signaling: size isn't everything, even in Drosophila. Differentiation 71, 375-397

Goewie, E. A. (1978) Regulation of caste differentiation in the honey bee (Apis mellifera L.) Mededelingen Landbouwhogeschool Wageningen - Nederland 78 (15) 1-75

Guidugli, K. R., Nascimento, A. M., Amdam, G.V., Barchuk, A. R., Omholt, S., Simões, Z. L. P., Hartfelder, K. (2005). Vitellogenin regulates hormonal dynamics in the worker caste of a eusocial insect. Federation of European Biochemical Societies 579, 4961-4965

Hammock, B.D. (1985) Regulation of juvenile hormone titer: Degradation. In: Kerkut, G.A., Gilbert, L.I (Eds), Comprehensive Insect Physiology, Biochemistry and Pharmacology, vol.2. Pergamon Press, New York, 431-472. 
Hansen, I.A., Attardo, M.G., Roy, S.G., Raikhel,A.S. (2005) Target of Rapamycindependent Activation of S6 Kinase Is a Central Step in the Transduction of Nutritional Signals during Egg Development in a Mosquito. The Journal of Biological Chemistry 280 (21), 20565-20572.

Hartfelder, K. (1993) Structure and function of the prothoracic gland in honey bee (Apis mellifera L.) development. Invertebrate Reproduction and Development 23, 59-74.

Hartfelder, K., Köstlin, K. Hepperle, C. (1995) Ecdysteroid-dependent protein synthesis in caste-specific development of the larval honey bee ovary. Roux's Archives of Developmental Biology 205, 73-80.

Hartfelder, K. \& Engels, W. (1998). Social insect polymorphism: hormonal regulation of plasticity in development and reproduction in the honeybee. Current Topics in Developmental Biology 40, 45-77

Hartfelder, K. (2000)a. Insect juvenile hormone: from "status quo" to high society. Brazilian Journal of Medical and Biological Research 33, 157-177

Hartfelder, K. (2000)b. Arthropoda- Insecta: Caste Differentiation Reproductive Biology of Invertebrates/ 10B,185-204

Hartfelder, K. \& Emlen, D. J. (2005) Endocrine control of insect polyphenisms. In Comprehensive Insect Molecular Science (L. I. Gilber, K. latrou, and S. J. Gill, Eds.), Vol. 3, pp. 653-704. Elsevier, Oxford.

Haydak, H. M. (1970) Honey Bee Nutrition. Annual Review of Entomology 15, $143-$ 156

Haydak, H. M. (1943) Larval Food and Development of Castes in the Honeybee. Journal of Economic Entomology 36, 779-793

Kim, J. J. \& Accili, D.(2002) Signalling through IFG-1and insulin receptors: Where is the specificity? Growth Hormone \& IGF Research 12:84-90 
Makert, G.R., Paxton, R.J., Hartfelder,K. (2006) Ovariole number-a predictor of differential reproductive succes among worker subfamilies in queenless honeybee (Apis mellifera L.) colonies. Behavioral Ecology and Sociobiology 60, 815-825.

Michellete, E.R.F. \& Soares, A.E.E. (1993) Characterization of preimaginal developmental stages in Africanized honey bee workers (Apis mellifera L.). Apidologie 24, 431-440.

Michener, C.D. (1974) The social behavior of the bees: a comparative study. Cambridge, Mass., Harvard Univ. Press.

Michener, C.D. (2000) The Bees of the World. John Hopkins University Press, Baltimore.

Mirth, C., Truman, J.W., Riddiford, L.M. (2005) The role of the prothoracic gland in determining critical weight for metamorphosis in Drosophila melanogaster. Current Biology 15 (20), 1796-1807.

Nascimento, A.M., Cuvillier-Hot, V., Barchuk, A.R., Simões, Z.L.P. \& Hartfelder, K. (2004). Honey bee (Apis mellfira) transferrin-gene structure and the role of ecdysteroids in teh developmental regulation of its expression. Insect Biochemistry and Molecular Biology 34, 415-424.

Nelson, C.M., Ihle, K.E., Fondrk, M.K., Page-Jr., R.E., Amdam, G.V. (2007) The gene vitellogenin has multiple coordinating effects on social organization. PLOSbiology 5 (3), 673-677.

Nijout, H.F. (1994) Insect hormones. Princeton University Press, Princeton, New Jersey.

Nijhout, H.F. (1999) Control mechanisms of polyphenic development in insects. BioScience 49, 181-192 
Nijhout, H.F. (2003) The control of growth. Development 130, 5863-5867.

Nunes-Silva, P., Gonçalves, L. S., Francoy, M. T., Jong, D. D. (2006) Rate of growth and development time of africanized honey bee (Apis mellifera) queens and workers during ontogenetic development. Brazilian Journal fo Morphological Sciences 23 (3-4), 325-332

Oldham, S. \& Hafen, E. (2003). Insulin/IGF and target of rapamycin signaling: a TOR de force in growth control. Trends in Cell Biology 13, 79-85

Page, R. E. \& Peng, C.Y.S. (2001) Aging and development in social insects with emphasis on the honey bee, Apis mellifera L. Experimental Gerontology 36, 695-711

Patel, A., Fondrk, k.M., Kaftanoglu, O., Hunt, G., Amdam, G.V. (2007) The making of a queen: TOR pathway governs diphenic caste development (submetido).

Pfaffl, M.W. (2001) A new mathematical model for relative quantification in real-time RT-PCR. Nucleic Acids Research 29, 2002-2007

Puig, O., Marr, M.T., Ruhf, L.M. e Tjian, R. (2003) Control of cell number by Drosophilai FOXO: downstream and feedback regulation of the insulin receptor pathway. Genes \& Development 17, 2006-2020

Puig, O. \& Tijian, R. (2005) Transcriptional feedback control of insulin receptor by dFOXO/FOXO1. Genes \& Development 19, 2435-2446

Puig,O. \& Tjian, R. (2006) Nutrient Availability and Growth: regulation of Insulin Signaling by dFOXO/FOXO1. Cell Cycle 5, 503-505

Rachinsky, A., Strambi, C., Strambi, A., Hartfelder, K. (1990) Caste and metamorphosis: hemolymph titers of juvenile hormone and ecdysteroids in last instar honey bee larvae. General and comparative endocrinology 78, 31-38. 
Radimerski, T., Montagne, J., Hemmings-Mieszczak, M., Thomas, G. (2002) Lethality of Droshophila lacking TSC tumor suppressor function rescued by reducing dS6k signaling. Genes \& Development 16, 2627-2632.

Radimerski, T., Montagne, J., Rintelen, F., Stocker, H., Van-der-Kaay, J., Downes, C. P., Hafen, E., Thomas, G. (2003). dS6K-regulated cell growth is dPKB/Dpi(3)Kindependent, but requires dPDK1. Nature Cell Biology 4, 251-255

Ratnieks, F.L.W. (1993) Egg-laying, egg-removal, and ovary development by workers in queenringht honey bee colonies. Behavioral Ecology and Sociobiology 32 , 191-198.

Reginato, R. D. \& Cruz-Landim, C. (2003) Ovarian growth during larval development of queen and worker of Apis mellifera (Hymenoptera: Apidae): A morphometric and histological study. Brazilian Journal of Biology 63(1), 121-127

Reiss, M.J. (1989) The allometry of growth and reproduction. Cambridge University Press, Cambridge.

Rembold, H \& Hanser, G. (1964) On the royal jelly of honey bees. 8. Demonstration of the determining principle in the jelly of queen bee larvae. Hoppe-Seyler Zeitschrift der Physiologische Chemie 339(1), 251-254

Rembold, H., Czoppelt, C., Rao, P.J. (1974) Effect of juvenile hormone treatment on caste differentiation in the honeybee, Apis mellifera. Journal of Insect Physiology 20, 1193-1202.

Rembold, H.; Kramer, J.P.; Ulrich, G.M. (1980). Characterization of postembryonic developmental stages of the female castes of the honey bee, Apis mellifera $\mathrm{L}$. Apidologie 11, 29-38

Rembold, H. (1987). Caste specific modulation of juvenile hormone titers in Apis mellifera. Insect Biochemistry. 17, 1003-1006 
Rembold, H. (1988) Die Aufklärung der Kastenentstehung im Bienenstaat in: Ditfurthm H. V. (ed) Mannheimer Forum 87/88,167-231.

Richard, S. D., Rybczynski, R. Wilson, T. G., Wang, Y., Wayne, M. L., Zhou, Y., Partridge, L., Harshman, L. G. (2005) Insulin signaling is necessary for vitellogenesis in Drosophila melanogaster independent of the roles of juvenile hormone and ecdysteroids: female sterility of the chico insulin signaling mutation is autonomous to the ovary. Journal of Insect Physiology 51, 455-464

Robinson, G. E., Strambi, C., Strambi, A., Huang, Z.Y. (1992) Reproduction in worker Money bees is associated with low juvenile hormone titers and rates of biosynthesis. General and Comparative Endocrinology 87, 471-480.

Roe, R.M. \& Venkatesh, K. (1990) Metabolism of juvenile hormones: degradation and titer regulation. In: Rutgers, G. A. (Ed.), Morphogenetic Hormones of Arthropods, vol. 1. University Press, New Brunswick, 126-179.

Ruan, Y., Chen, C. Cao, Y. Garofalo, R.S. (1995) The Drosophila insulin receptor contains a novel carboxyl-terminal extension likely to play an important role in signal transduction. The Journal of Biological Chemistry 270 (9) 4236-4243.

Sambrook, J. Fritsch, E.F., Maniatis.T (1989) Molecular Cloning- A Laboratory Manual 2ed., Cold Spring Harbor Laboratory Press, Cold Spring Harbor.

Seehuus, S-C., Norberg, K., Gimsa, U., Krekling, T., Amdam, G.V (2006) Reproductive protein protects funcionally sterile honey bee workers from oxidative stress. Proceedings of the National Academy of Science 103, 962967.

Schmidt-Capella, I.C. \& Hartfelder, K. (1998) Juvenile hormone effect on DNA synthesis and apoptosis in caste specific differentiation of the larval honey bee (Apis mellifera L.) ovary. Journal of Insect Physiology 44, 385-391

Stern, D. (2003). Body-size control: how an insect knows it has grown enough. Current Biology 13, R267-R269 
Stern, D.L. \& Emlen, D.J. (1999) The developmental basis for allometry in insects. Development 126, 1091-1101

Tanaka, D.E., Schmidt-Capella, I.C., Hatfelder, K. (2006) Cell death in the germilinemechanisms and consequences for reproductive plasticity in social bees. . Brazilian Journal fo Morphological Sciences 23 (1), 467-500.

Tatar, M., Kopelman, A., Epstein, D., Tu, M.-P., Yin, C.-M. (2001) A mutant Drosophila insulin receptor homolog that extends life-span and impairs neuroendocrine function. Science 292, 107-110.

Tatar, M., Bartke, A., Antebi, Adam (2003) The endocrine regulation of aging by insulin-like signals. Science 299, 1346-1351.

The Honeybee Genome Sequencing Consortium (2006) Insights into social insects from the genome of the honeybee Apis mellifera. Nature 44, 931-949.

Thomas, G. (2000) An encore for ribosome biogenesis in the control of cell proliferation. Nature Cell Biology 2, E71-E72.

Truman, J.W. \& Riddiford, L.M. (2002) Endocrine insights into the evolution of metamorphosis in insects. Annual Review of Entomology 47, 467-500.

Van Sluijters, D. A., Dubbelhuis, P.F., Blommaart, E.F., Meijer, A.J. (2000) Aminoacid-dependent signal transduction. Biochemical Journal 351, 545-550.

Weaver, N. (1957) Effects of larval age on dimorphic differentiation of the female honey bees (Apis mellifera L, Hymenoptera: Apidae) Annals of the Entomological Society of America 50, 283-294.

Wheeler, D.E; Buck, N; Evans, J.D. (2006) Expression of insulin pathway genes during the period of caste determination in the honey bee, Apis mellifera. Insect Molecular Biology 15 (5), 597-602 
Wilde, J. De (1976) Juvenile hormone and caste differentiation in honey bee (Apis mellifera L.). In: Phase and Caste Determination in Insects (M. Lücher, ed.) pp.5-20. Pergamon Press, Oxford

Wilde, J. De \& Beetsma, J. (1982) The Physiology of Caste Development in Social Insects Advances in Insect Physiology 16,167-246

Wilson, E.O. (2006) How to make a social insect. Nature 443, 919-920.

Winston, M. L. (1987) The Biology of the honey bee. Harvard University Press. Cambridge, MA.

Wittwer, F; Jquenoud, M; Brogiolo, W; Zarske, M; Wüstemann, P; Fernandez, R; Stocker, H; Wymann, M and Hafen, E. (2005) Susi, a Negative Regulator of Drosophila PI3-Kinase. Developmental Cell 8, 817-827

Wu, Q. \& Brown, M.R. (2006) Signaling And Funcion Of Insulin-Like Peptides In Insects. Annual Review of Entomology 51, 1-24.

Yenush, L., Fernandez, R., Myers, M.G., Jr, Grammer, T.C., Sun, X.J., Blenis, J., Pierce, J. H., Schlessinger, J. and White, M.F. (1997) The IRS-signalling system during insulin and cytokine action. BioEssays 19, 491-500.

\section{Portais Internet utilizados:}

www.hgsc.bcm.tmc.edu/projects/honeybee/

http://align.genome.jp/

$\underline{\text { http://zulu.fmrp.usp.br/beelab }}$

http://www.ncbi.nlm.nih.gov/

www.uni-bayreuth.de/.../toek1/fortner/index.htm

http://frodo.wi.mit.edu/cgi-bin/primer3/primer3 www.cgi 